UNIVERSIDADE DE SÃO PAULO

FACULDADE DE ARQUITETURA E URBANISMO

\title{
BANCOS DE DADOS GEOGRÁFICOS E SISTEMAS DE INFORMAÇÕES GEOGRÁFICAS PARA CADASTRAMENTO \\ IMOBILIÁRIO: Requisitos, Modelos e Aplicações
}

KAUÊ OBARA KURIMORI

Dissertação apresentada à Faculdade de Arquitetura

e Urbanismo da Universidade de São Paulo para concorrer ao Título de Mestre pelo Curso de PósGraduação em Arquitetura e Urbanismo

São Paulo 
UNIVERSIDADE DE SÃO PAULO

FACULDADE DE ARQUITETURA E URBANISMO

\section{BANCOS DE DADOS GEOGRÁFICOS E SISTEMAS DE INFORMAÇÕES GEOGRÁFICAS PARA CADASTRAMENTO \\ IMOBILIÁRIO: Requisitos, Modelos e Aplicações}

KAUÊ OBARA KURIMORI

Dissertação apresentada à Faculdade de Arquitetura

e Urbanismo da Universidade de São Paulo para concorrer ao Título de Mestre pelo Curso de PósGraduação em Arquitetura e Urbanismo

Área de Concentração: Planejamento Urbano e Regional Orientador: Prof. Dr. Nuno de Azevedo Fonseca

São Paulo 

Data da Defesa:

1

BANCA EXAMINADORA

Prof. Dr.

Julgamento:

Assinatura:

Prof. Dr.

Julgamento:

Assinatura:

Prof. Dr.

Julgamento:

Assinatura:

Prof. Dr.

Julgamento:

Assinatura: 
Àqueles que influenciaram a realização deste estudo. 


\section{AGRADECIMENTOS}

À instituição, pela oportunidade;

Aos professores e ao orientador, pela dedicação e apoio;

Aos amigos e colaboradores, pela compreensão e contribuição;

À minha família. 


\section{ERRATA}

\section{No RESUMO,}

Onde se lê:

Palavras-chave: Banco de dados geográfico; sistema de informações geográficas; cadastro imobiliário urbano; gestão e planejamento urbano.

Leia-se:

Palavras-chave: banco de dados; sistema de informação geográfica; cadastro técnico municipal; planejamento territorial urbano.

\section{No ABSTRACT,}

Onde se lê:

Key-words: geographic data base; geographic information system; urban building cadaster; urban management and planning.

Leia-se:

Key-words: spatial databases; geographic information system; technical cadaster; urban territorial planning.

Na página 4, linha 4 ,

Onde se lê:

... implementado ...

Leia-se:

... implementada ...

Na página 5 , linha 6 ,

Onde se lê:

... destaca-se-se ...

Leia-se:

... destaca-se ...

Na página 37, linha 2,

Onde se lê: 
... ensina (camara intrid cap 3 p5) ...

Leia-se:

... ensinam Câmara \& Queiroz (2001) ...

Na página 53, linha 10,

Onde se lê:

... na data d aprovação ...

Leia-se:

... na data de aprovação ... 


\section{SUMÁRIO}

\section{Capítulo 1 Introdução}

Objeto, objetivos e método

Capítulo 2 Requisitos e Modelos para Bancos de Dados Geográficos

Nível descritivo, nível conceitual e nível computacional

2.1 Dados geográficos

2.2 Entidades

2.3 Bancos de dados geográficos

\section{Capítulo 3 Utilização de Banco de Dados Geográficos}

Simulação de cálculo de valor de Outorga Onerosa do

Direito de Construir

Capítulo 4 Conclusão 


\section{LISTA DE FIGURAS}

Figura 1 - "Arquitetura de Sistemas de Informação Geográfica" ............................... 3

Figura 2 - "Níveis de abstrações" . ............................................................................. 7

Figura 3 - "Níveis de especificação de aplicações geográficas" ............................... 8

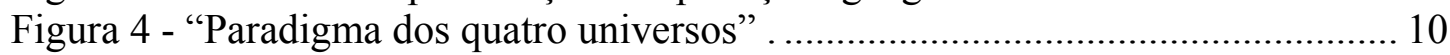

Figura 5 - "Exemplo de mapa cadastral (países da América do Sul)" ....................... 15

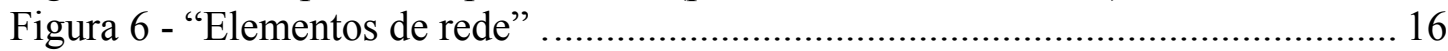

Figura 7 -"Superfície e grade regular correspondente (Fonte: Namikawa,

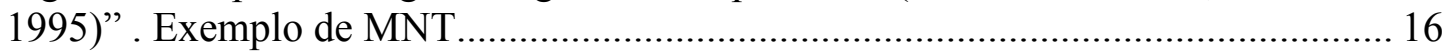

Figura 8 - Exemplo de imagem. WorldView-2, Digital Globe ............................... 17

Figura 9 - "Estrutura Matricial" ........................................................................ 18

Figura 10 - Imagem do satélite Quick Bird, georreferenciada e ortorretificada, da área urbana do município de Lins (2003). Fonte: BASE

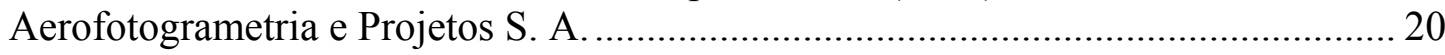

Figura 11 - "Diferentes representações matriciais para um mapa" .......................... 21

Figura 12 - "Representações vetoriais em duas dimensões." ..................................... 24

Figura 13 - "Dualidade entre espaço absoluto e espaço relativo. À esquerda, distritos de São Paulo com suas fronteiras. À direita grafo mostrando a rede de conectividade entre os distritos (espaço relativo). O mapa da esquerda foi

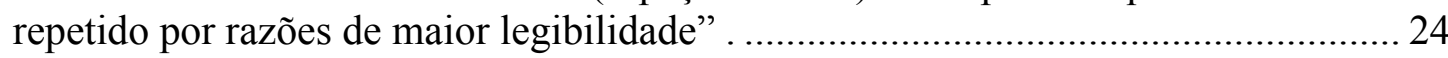

Figura 14 - "Estrutura topológica do tipo arco-nó-polígono" ................................. 25

Figura 15 - "Representação vetorial e matricial de um mapa temático" .................... 26

Figura 16 - Planta-quadra com indicação dos dados e informações. Fonte:

Prefeitura Municipal de Lins. Elaborado por: Fundação Paulista de

Tecnologia e Educação - Centro de Tecnologia em Geoprocessamento.................... 28

Figura 17 - Vetorização da base cartográfica sobre imagem de satélite no software AutoCAD.

Figura 18 - "Exemplo de geo-campo (imagem IKONOS do Rio de Janeiro)

e de conjunto de geo-objetos (distritos da cidade de São Paulo)" . ............................. 31

Figura 19 - "Exemplo de ligação entre geo-objeto e objeto não-espacial" ................. 31

Figura 20 - Vetorização da base cartográfica no software AutoCAD sobre

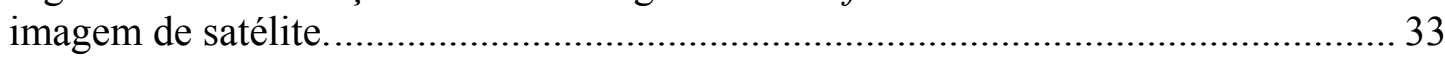

Figura 21 - "Exemplos do relacionamento dentro de (contido em)." ......................... 34

Figura 22 - "Arquitetura Dual" e "Arquitetura Integrada". ...................................... 36

Figura 23 - Entidades componentes do sistema de informações geográficas............. 40

Figura 24 - Mapa dos imóveis a serem vistoriados, obtidos por meio do

sistema de informações geográficas.

Figura 25 - Relatório gerado pelo sistema de informações geográficas para

orientação das visitas em campo, contendo endereço, área cadastrada, área

vetorizada, diferença de áreas, padrão de acabamento, entre outras

informações pertinentes.

Figura 26 - Interface customizada da "tela de cadastro".......................................... 44

Figura 27 - Tela do software de sistema de informações geográficas

desenvolvido pela entidade responsável no caso estudado. 
Figura 28 - Definição da apresentação visual da entidade "lote" pela relação entre os atributos: área construída (IMVFEAAREAPF) e área do terreno (IMVFEAAREATF). Graduação do resultado (Coeficiente de Aproveitamento) por cores (graduated colors). (Detalhe em destaque ampliado).

Figura 29 - Tratamento visual da entidade "lote", pela relação entre atributos de área construída e área do terreno, representando os valores de coeficiente de aproveitamento.

Figura 30 - Atributos da entidade "Imóvel". (Detalhe em destaque ampliado).

Figura 31 - Atributos da entidade "Lote". (Detalhe em destaque ampliado).............. 56

Figura 32 - Cálculo do $C A$. (Detalhe em destaque ampliado).................................... 57

Figura 33 - Cálculo do CAda. (Detalhe em destaque ampliado). .............................. 57

Figura 34 - Atributos adicionados à tabela de atributos da entidade "Lote":

$C A$ e $C A d a$. (Detalhe em destaque ampliado)........................................................ 58

Figura 35 - Coluna transposta ZAFFEAVALORF (valor venal unitário da

ZAF) da entidade "ZAF" para a entidade "Lote". (Detalhe em destaque ampliado).

Figura 36 - Colunas de atributos adicionadas: área construída final $(A C F) \mathrm{e}$

coeficiente de aproveitamento final $(C A F)$. (Detalhe em destaque ampliado)

Figura 37 - Cálculo da $C A F$. (Detalhe em destaque ampliado).

Figura 38 - Cálculo do Voodc com utilização de duas expressões,

condicionadas ao valor do CAda. (Detalhe em destaque ampliado).

Figura 39 - Imóvel selecionado com $C A s c d a$ menor que zero. (Destaque).

Figura 40 - Inserção de valor para $A C F$. (Detalhe em destaque ampliado)................ 62

Figura 41 - Voodc (Valor da Outorga Onerosa do Direito de Construir)

obtido na simulação. (Detalhe em destaque ampliado).

Figura 42 - Imóvel selecionado com CAda maior ou igual a zero.

(Destaque).

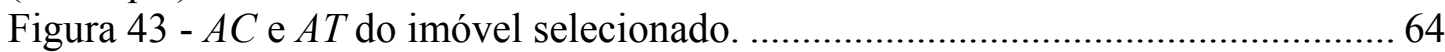

Figura 44 - Cálculo do Voodc (Valor da Outorga Onerosa do Direito de

Construir).

Figura 45 - Aplicação para consulta de foto de fachada de imóvel. ........................... 70

Figura 46 - Aplicação para consulta aos dados do Boletim de Informações

Cadastrais (BIC), que pode ser gerado pelo sistema de informações

geográficas. 
LISTA DE TABELAS

Tabela 1 - Parâmetros das imagens do satélite Quick Bird........................................ 22

Tabela 2 - Comparação entre estruturas vetoriais e matriciais para mapas

temáticos 


\section{RESUMO}

Diferentes administrações públicas municipais adotam bancos de dados geográficos e sistemas de informações geográficas como ferramentas auxiliares para realização de procedimentos relacionados ao cadastramento de imóveis urbanos. Consequentemente, tais sistemas são desenvolvidos de acordo com diferentes realidades e demandas e têm diferentes características. Nesse mesmo sentido, observa-se que a tecnologia proporciona diversas possibilidades de concepção e a adoção de diferentes modelos. Não obstante, por razões de eficiência, determinados modelos se apresentam como vantajosos para bancos de dados geográficos e sistemas de informações geográficas voltados para cadastramento imobiliário urbano, seja do ponto de vista de sua implementação ou de seus resultados. O presente estudo procura abranger os principais modelos disponíveis e suas características, porém dá maior ênfase para a aplicação efetiva da tecnologia, por meio da adoção de um estudo de caso, com o objetivo de analisar o potencial de utilização dos bancos de dados geográficos, implementados com tais propósitos, para aplicação em outras áreas de atuação da administração pública municipal, em especial na gestão e no planejamento urbano.

Palavras-chave: Banco de dados geográfico; sistema de informações geográficas; cadastro imobiliário urbano; gestão e planejamento urbano. 


\begin{abstract}
Different municipal government administrations use geographic data bases and geographic information systems as tools for urban buildings cadaster procedures. As a result, these systems are developed according to the different realities and demands, having different characteristics. In the same way, it's observed that the technology allows many conception possibilities and the adoption of different models. By efficiency reasons, some models appear to be more helpful for geographic data bases and geographic information systems used to cadaster urban buildings, in the implementation point of view and for their results. The present research tries to look over the primary models offered and their characteristics, but giving special attention for the effective application of the technology by adopting a case study, it tries to analyze the utilization potential of the geographic data bases, used for those purposes, to be applied on other municipal administration areas, specially on the management and on the urban planning.
\end{abstract}

Key-words: geographic data base; geographic information system; urban building cadaster; urban management and planning. 


\section{AUTORIZAÇÃo}

Autorizo a reprodução e/ou divulgação total ou parcial da presente obra, por qualquer meio convencional ou eletrônico, desde que citada a fonte.

Kauê Obara Kurimori

São Paulo, 2012. kaue@usp.br 


\section{Capítulo 1 - Introdução}

\section{Objeto, objetivos e método}

O presente estudo integra o curso de mestrado da Faculdade de Arquitetura e Urbanismo da Universidade de São Paulo, e tem como objeto a tecnologia em bancos de dados geográficos e sua aplicação em sistemas de informações geográficas, utilizadas para apoiar a regularização de áreas construídas urbanas e constituir ferramenta computacional para operacionalização de procedimentos pertinentes ao cadastro imobiliário urbano no âmbito de administrações municipais.

As diferentes formas e abordagens para a definição de sistemas de informações geográficas denotam sua natureza interdisciplinar e sua capacidade de abranger uma multiplicidade de usos e aplicações.

Segundo Câmara (1995), o termo sistemas de informações geográficas (SIG) é aplicado para sistemas que realizam o tratamento computacional 
de dados geográficos. Entre outras definições para sistemas de informações geográficas, cita:

"Um conjunto manual ou computacional de procedimentos utilizados para armazenar e manipular dados georreferenciados”. (Aronoff, 1989 apud Câmara, 1995).

"Conjunto poderoso de ferramentas para coletar, armazenar, recuperar, transformar e visualizar dados sobre o mundo real”. (Burrough, 1986 apud Câmara, 1995).

"Um sistema de suporte à decisão que integra dados referenciados espacialmente num ambiente de respostas a problemas". (Cowen, 1988 apud Câmara, 1995).

"Um banco de dados indexados espacialmente, sobre o qual opera um conjunto de procedimentos para responder a consultas sobre entidades espaciais". (Smith et al., 1987 apud Câmara, 1995).

Câmara (1995) afirma ainda que sistemas de informações geográficas são compostos de interface com o usuário, entrada e integração de dados, funções de consulta e análise espacial, visualização e plotagem, armazenamento e recuperação de dados (organizados sob a forma de um banco de dados geográfico). 


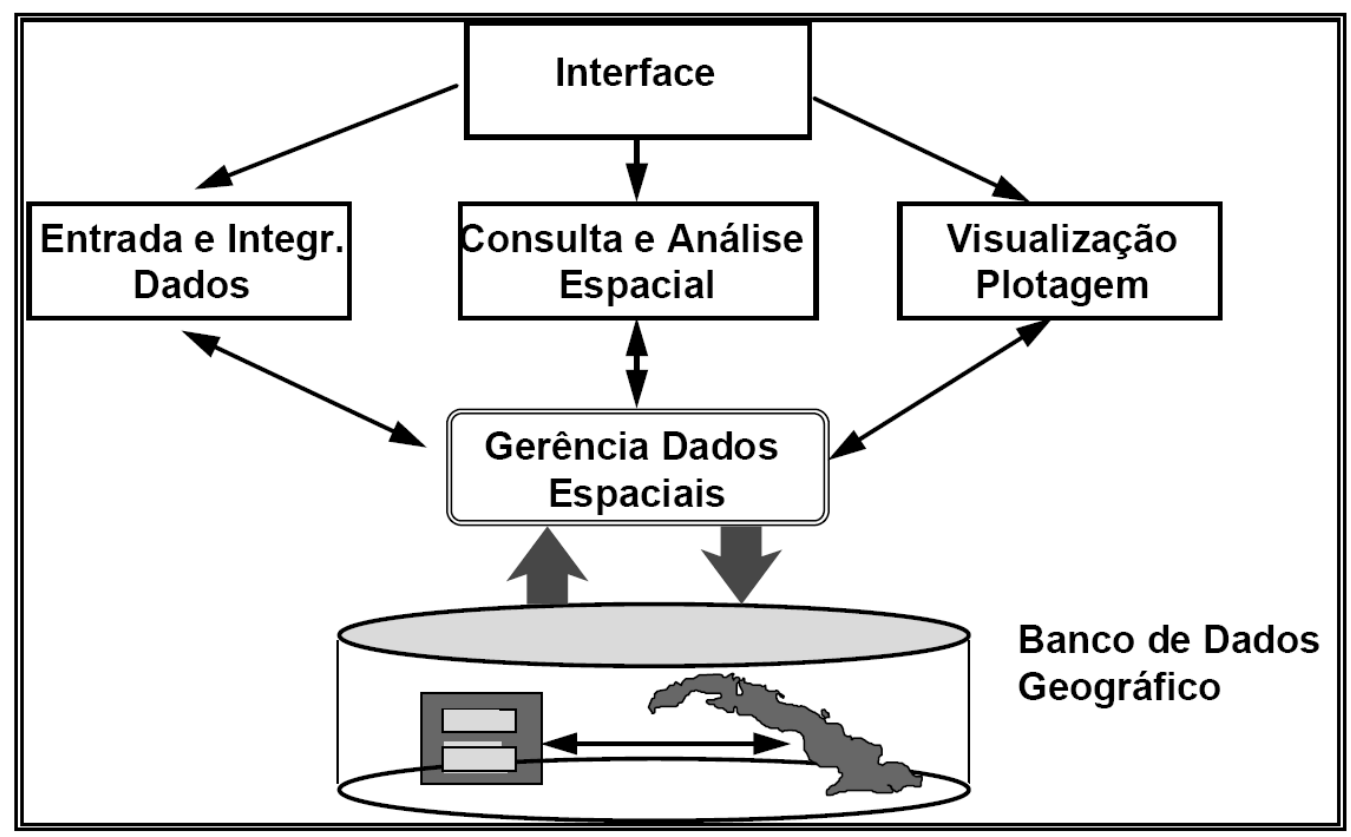

Figura 1 - "Arquitetura de Sistemas de Informação Geográfica" 1.

Uma das principais características fundamentais dos sistemas de informações geográficas é a capacidade de abranger a natureza dual dos dados geográficos, sua localização no espaço e seus atributos descritivos, em um sistema de banco de dados geográficos, capaz de relacionar espacialmente os diferentes objetos representados em uma estrutura de relacionamentos topológicos. Os SIGs tem a capacidade de representar as relações espaciais entre os diferentes objetos que compõem a base de dados e realizar operações de análise espacial, diferenciando-se das tecnologias CAD (Computer Aided Design).

Por tais características, os sistemas de informações geográficas têm sido utilizados em diversas aplicações onde a espacialização dos elementos que

${ }^{1}$ CÂMARA, G. Modelos, linguagens e arquiteturas para banco de dados geográficos. São José dos Campos. Tese de doutorado em computação aplicada - Instituto Nacional de Pesquisas Espaciais INPE, 1995. Disponível em <http://www.dpi.inpe.br/teses/gilberto/>. 12 p. 
compõem o sistema de banco de dados é fundamental para que sejam atingidos os seus objetivos. O presente estudo abrange a utilização da tecnologia em sistemas de informações geográficas para identificação de áreas construídas urbanas e enquanto ferramenta para gestão de cadastro imobiliário urbano municipal, implementado especificamente em função dos requisitos para tais finalidades, visando caracterizar os sistemas, para analisar sua potencial utilização em procedimentos relativos à gestão e ao planejamento urbano municipal. Observa-se ainda que o presente estudo limita-se a abranger a concepção conceitual dos componentes e modelos de sistemas de informações geográficas no que diz respeito aos aspectos espaciais e fenômenos reais inerentes aos seus objetivos, ou seja, aos dados geográficos. Assim, outras definições essenciais para a efetiva implementação de um sistema de informações geográficas, como acesso e restrições, volume e processamento de dados, interoperabilidade, etc. não são enfocados.

Diferentes administrações municipais adotam bancos de dados geográficos e sistemas de informações geográficas como ferramentas auxiliares na realização de procedimentos relacionados ao cadastro imobiliário urbano, incluindo a regularização de áreas construídas. Consequentemente, tais sistemas são desenvolvidos de acordo com diferentes realidades e demandas e têm diferentes características. Nesse mesmo sentido, observa-se que a tecnologia dos sistemas de informações geográficas proporciona diversas possibilidades de concepção conceitual, a partir de diferentes modelos. Não obstante, destaca-se que, por razões de eficiência, determinados modelos se apresentam como vantajosos em sistemas de informações geográficas voltados para cadastramento imobiliário urbano, seja do 
ponto de vista de sua implementação ou de seus resultados. O presente estudo procura abranger conceitualmente os principais modelos e suas características, porém dá maior ênfase para a aplicação efetiva da tecnologia, na medida em que é adotado um estudo de caso de sistema de informações geográficas implantado.

Destaca-se-se que, uma vez que tais sistemas objetivam auxiliar administrações públicas municipais na regularização de imóveis e na operacionalização de procedimentos relativos aos seus cadastros imobiliários urbanos, devem ser constituídos por dados e informações de caráter oficial, de modo a viabilizar sua utilização no atendimento às necessidades da administração municipal e a respeitar o princípio da legalidade.

No que diz respeito à base de dados, os sistemas de informações geográficas contém as características de sistemas de banco de dados convencionais (não geográfico), como armazenamento, manipulação, análise, recuperação e seleção de dados. Uma vez que o componente geográfico, ou espacial, dos elementos se integra à base de dados, o sistema amplia seu potencial de utilização, para regularização de áreas construídas no cadastro imobiliário, mas também para o atendimento de outras demandas diversas, inclusive de gestão e planejamento urbanos. Ocorre, no entanto, que, muitas vezes, observa-se a subutilização desse potencial, na medida em que este não é considerado desde o início do processo de concepção do sistema. Assim, considerando-se que tal potencial de utilização decorre do uso da tecnologia computacional de sistemas de informações geográficas, que inclui o componente espacial, sua concepção e implementação, ainda que de 
iniciativa oriunda de demandas de cadastro imobiliário, atenderá mais efetivamente às demandas da administração municipal na medida que considerar também, entre os requisitos do sistema, as demandas oriundas de outras áreas, em especial do urbanismo e do planejamento urbano municipal.

Portanto, o objetivo do presente estudo é analisar o potencial de utilização de sistemas de informações geográficas, concebidos para a regularização de áreas construídas e para a operacionalização de procedimentos relativos ao cadastro imobiliário urbano municipal, em outras áreas de atuação da administração pública municipal, em especial na gestão e planejamento urbanos, a partir da caracterização e análise dos modelos adotados em função dos requisitos específicos de tais sistemas.

Para a caracterização dos referidos sistemas de informações geográficas, foi adotado o método proposto por Setzer \& Silva (2005) para a concepção e desenvolvimento de bancos de dados, baseado no conceito de diferentes níveis de abstração, relacionados a diferentes etapas ou fases do desenvolvimento de um sistema de banco de dados, desde o "mundo real" até "nível interno", ou seja, desde a identificação dos elementos da realidade pertinentes ao modelo até o nível sintático da implementação em ambiente computacional.

O método propõe que o processo de modelagem de dados se dê em cinco níveis de abstração, convenientes aos objetivos do sistema, derivados uns 
dos outros, na seguinte sequência: "mundo real", "modelo descritivo", "modelo conceitual", "modelo computacional" e "modelo interno".

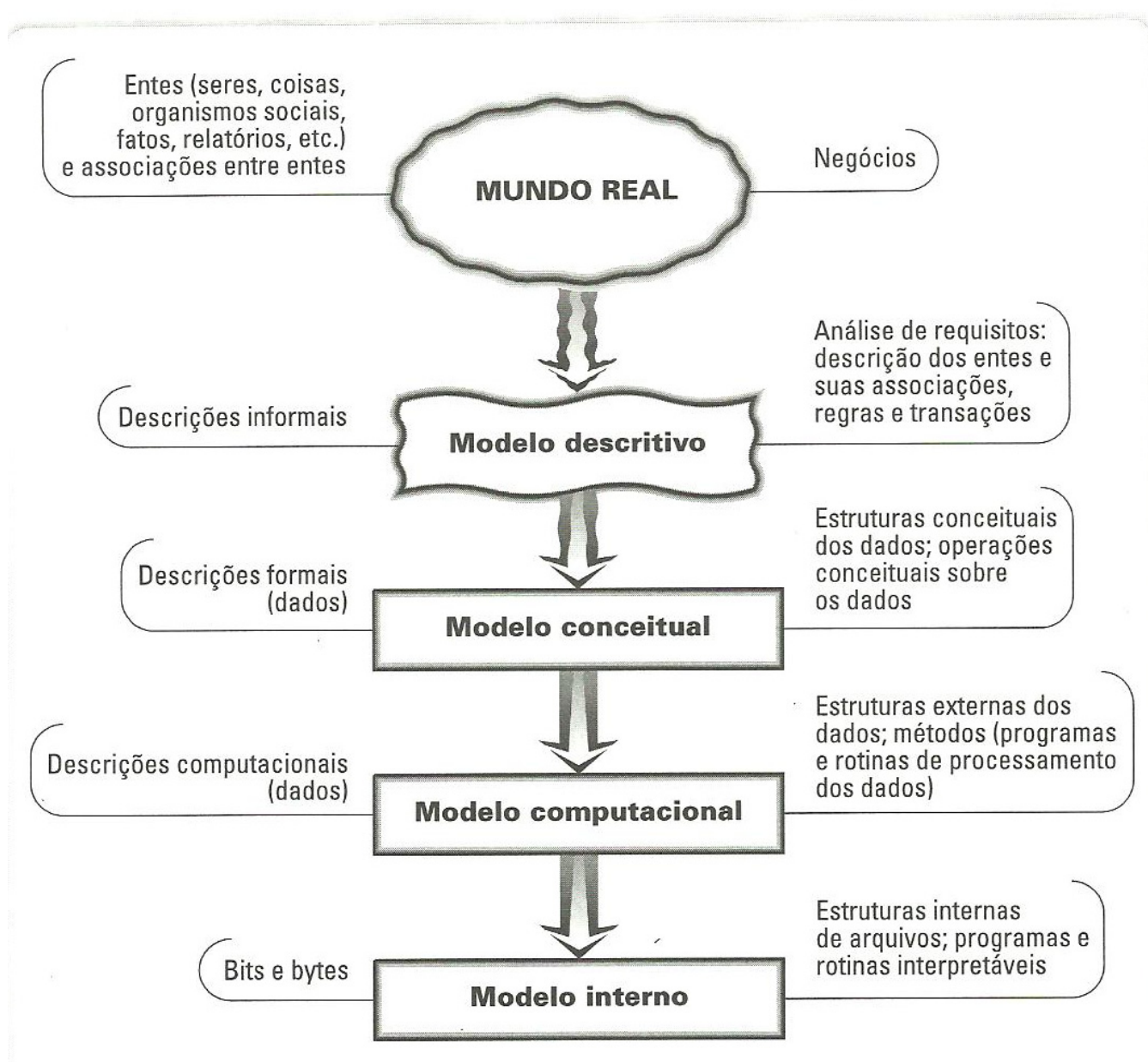

Figura 2 - "Níveis de abstrações" 2 .

Giacaglia (1998) descreve o método da seguinte maneira:

"Cada nivel de abstração utilizado corresponde a uma fase do projeto e a um tipo de modelo. Em geral parte-se de uma especificação escrita (modelo descritivo) para se elaborar um modelo conceitual. A partir do modelo conceitual são derivados programas, em uma linguagem de programação (modelo operacional) que por

${ }^{2}$ SETZER, V. W. ; SILVA, F. S. C. Bancos de dados. São Paulo, Ed. Edgar Blücher Ltda, 2005. 8 p. 
sua vez é, por razões de eficiência, convertida em linguagem de máquina." (Giacaglia, 1998, p.11).

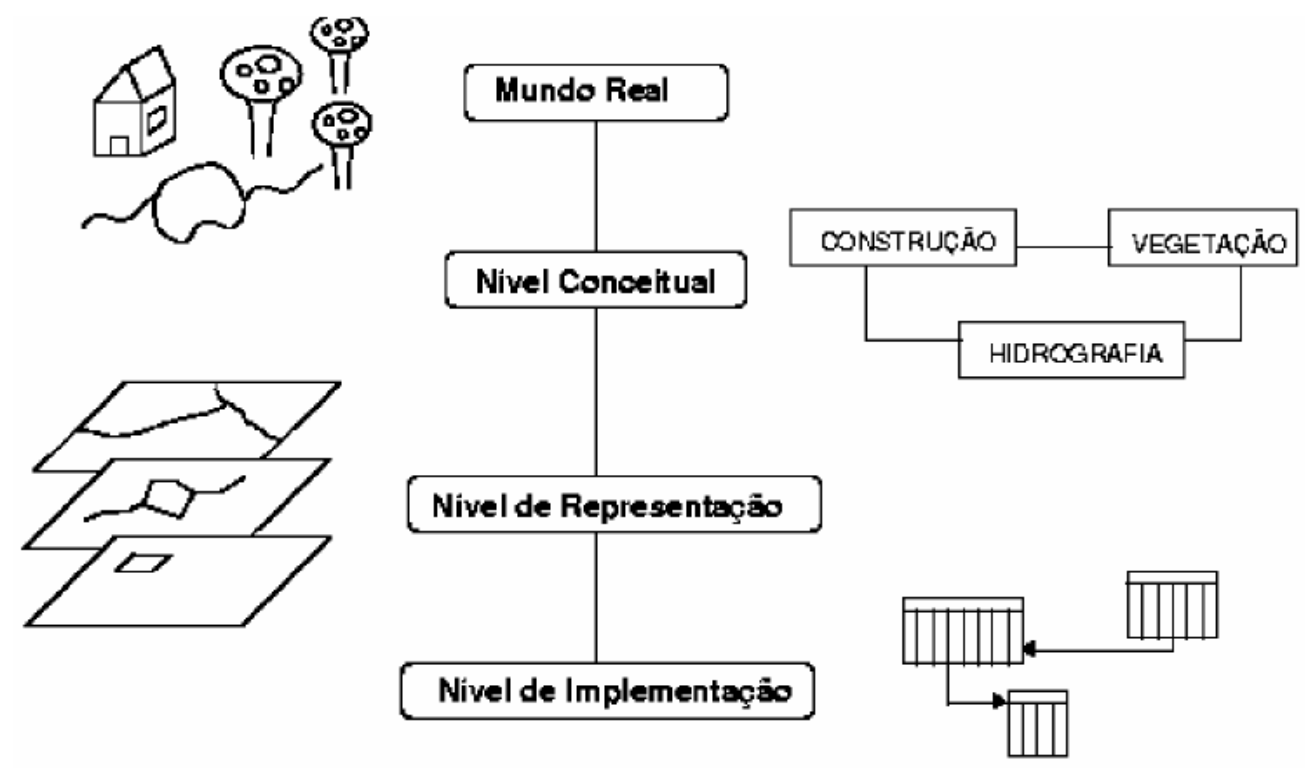

Figura 3 - "Níveis de especificação de aplicações geográficas" 3.

Segundo Setzer \& Silva (2005), o “nível descritivo", que já constitui um modelo da realidade, ainda que livre de regras formais, abrange as descrições informais necessárias para a compreensão das diretrizes derivadas do mundo real, no que é denominado de "Análise de Requisitos". Nessa primeira etapa de desenvolvimento de sistemas de bancos de dados, são definidos os objetivos e as diretrizes fundamentais para sua consecução, os elementos que compõem a base de dados, suas características e seus relacionamentos, ainda que informalmente.

O “nível conceitual” implica na formalização matemática e na organização da estrutura dos dados, fundamental para o processamento

\footnotetext{
${ }^{3}$ BORGES, K. ; DAVIS, C. Modelagem de Dados Geográficos. In: CÂMARA, G. et al. Introdução a Ciência da Geoinformação. São José dos Campos, Instituto Nacional de Pesquisas Espaciais INPE, 2001. Disponível em <http://www.dpi.inpe.br/gilberto/livro/introd/>. 4-14 p.
} 
computacional. Assim, os dados provenientes dos entes definidos no "nível descritivo" constituirão conjuntos abstratos matemáticos por meio da adoção de modelos conceituais. Ainda no "nível conceitual" devem ser formalizados os tratamentos dos dados, definidos como ações de definir, excluir, atualizar e selecionar os metadados, isto é, manipular as definições das estruturas de dados.

O "nível computacional" trata da introdução dos dados em computador, ou seja, da definição das possíveis representações geométricas associadas aos modelos do nível conceitual.

No "nível interno" são definidos padrões, formas de armazenamento e estruturas de dados para implementar cada tipo de representação, os relacionamentos entre elas e as funções e métodos necessários. Conforme apresentado anteriormente, o presente estudo abrange a concepção de sistemas de informações geográficas enquanto ferramenta computacional para o atendimento das demandas relativas a cadastros imobiliários e ao planejamento urbano, com ênfase no estudo de seus requisitos, conceitos e aplicações, portanto, o nível interno não será abordado.

Mais especificamente voltado para o desenvolvimento de bancos de dados geográficos, o processo proposto inicialmente por Gomes e Velho ${ }^{4}$, e adaptado para a geoinformação por Câmara (2005), se dá através de quatro

\footnotetext{
${ }^{4}$ GOMES, J.; VELHO, L. “Abstraction Paradigms for Computer Graphics. The Visual Computer”, v. 11, n.5, p. 227-239, 1995. apud CÂMARA, G. et al. Bancos de Dados Geográficos. São José dos Campos, Instituto Nacional de Pesquisas Espaciais - INPE, 2005. Disponível em $<$ http://www.dpi.inpe.br/livros/bdados/>. 4 p.
} 
"universos de abstração": "universo ontológico", "universo formal", "universo estrutural" e "universo de implementação". De forma geral, o "universo ontológico" abrange os aspectos relevantes da realidade; o "universo formal" visa a formalização matemática dos aspectos reais; o "universo estrutural" diz respeito a representação geométrica e alfanumérica dos objetos e o "universo de implementação" trata da viabilização computacional do modelo, com a definição de estruturas de dados e algoritmos.

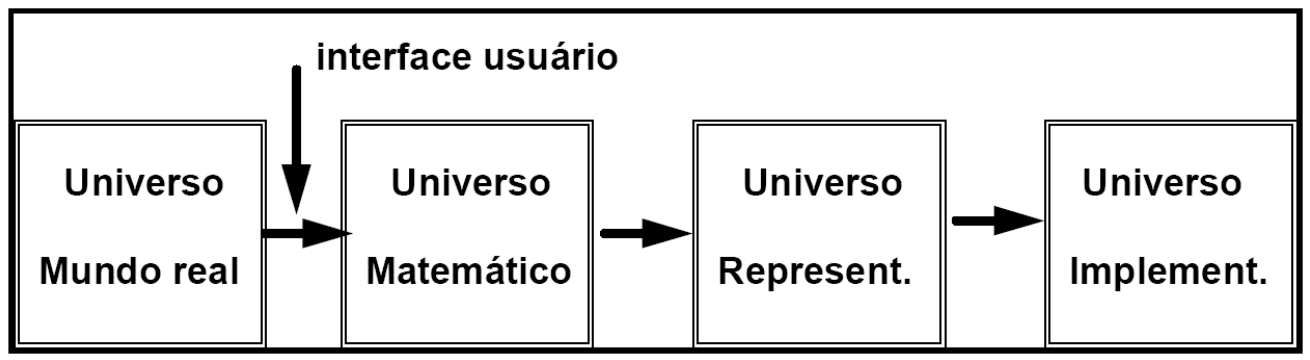

Figura 4 - "Paradigma dos quatro universos" 5.

Na comparação entre os métodos, observa-se correlação entre os "universos de abstração", propostos por Câmara (2005), e os "níveis de abstração", propostos por Setzer \& Silva (2005). Visando uma análise mais abrangente e acessível das características e do potencial dos sistemas de informações geográficas para gestão de cadastro imobiliário urbano, seus componentes fundamentais são apresentados sob a ótica da metodologia preconizada por Setzer \& Silva (2005). Com base nesse método, do estudo da constituição por modelos de sistema de informações geográficas para identificação de áreas construídas irregulares e para gestão de

${ }^{5}$ CÂMARA, G.; MONTEIRO, A. M. V. Conceitos Básicos em Ciência da Geoinformação. In: CÂMARA, G. et al. Introdução a Ciência da Geoinformação. São José dos Campos, Instituto Nacional de Pesquisas Espaciais - INPE, 2001. Disponível em

$<$ http://www.dpi.inpe.br/gilberto/livro/introd/>. 2-3 p. 
cadastro imobiliário, decorre a análise dos potenciais e limitações de tal sistema enquanto ferramenta para gestão e planejamento urbanos.

A estrutura de organização do presente estudo é composta por quatro capítulos. O presente "Capítulo 1 - Introdução", apresenta o objeto, objetivos e método do presente estudo. O "Capítulo 2 - Requisitos e Modelos para Bancos de Dados Geográficos", contempla a descrição e análise dos requisitos e modelos para bancos de dados geográficos, nos diferentes níveis de abstração. “O Capítulo 3 Utilização de Banco de Dados Geográficos”, exemplifica a utilização do banco de dados geográficos, por meio da simulação do cálculo de Outorga Onerosa do Direito de Construir, aplicada no software ArcGIS. Por fim, o "Capítulo 4 - Conclusão", contém as considerações e análises finais. 


\section{Capítulo 2 - Requisitos e Modelos para Bancos de Dados Geográficos}

\section{Nível descritivo, nível conceitual e nível computacional}

O presente capítulo constitui a análise das características dos bancos de dados geográficos e dos sistemas de informações geográficas para gestão de cadastro imobiliário urbano, com vistas à identificação de potenciais de aplicação para gestão de instrumentos de planejamento urbano, segundo a metodologia preconizada por Setzer \& Silva (2005), abordando os requisitos e modelos considerados na concepção do sistema no "nível descritivo", no "nível conceitual” e no "nível computacional”. O "nível interno", por se tratar de área do conhecimento cuja interface com a gestão e o planejamento urbanos apresenta menor relevância para o presente estudo, não será abrangido.

Adotou-se, como estudo de caso, o município de Lins - SP, onde foi realizada a implantação de banco de dados geográficos e sistema de informações geográficas objetivando a atualização dos dados do cadastro imobiliário, por meio da 
identificação de áreas construídas não regularizadas em área urbana, e a constituição uma ferramenta computacional permanente para a gestão do cadastro imobiliário para a administração municipal. A adoção de um estudo de caso tem como objetivo representar o processo de concepção de banco de dados geográficos e de sistema de informações geográficas efetivamente aplicados, por meio da descrição do método de implantação adotado, visando discorrer sobre a análise de requisitos e sua relação com os conceitos dos modelos adotados.

No caso estudado, um dos principais objetivos para a administração pública municipal na implantação de tal sistema implicava na identificação de áreas construídas irregularmente, visando sua regularização junto aos setores de cadastro imobiliário. Observa-se que tal atividade constitui atribuição dos setores de fiscalização, não dependendo do uso de tecnologias computacionais para tanto. Por outro lado, a utilização de técnicas de sensoriamento remoto permite a identificação de áreas construídas irregulares na comparação com os dados do cadastro imobiliário urbano, de modo a racionalizar os serviços de vistorias e levantamentos de campo, notadamente custosos. Outro dos principais objetivos refere-se à constituição de ferramenta computacional para gestão e operacionalização de procedimentos relativos ao cadastramento imobiliário urbano do município.

O método adotado para a identificação das áreas construídas não regularizadas, no caso estudado, se baseia na vetorização de base cartográfica urbana sobre imagem de satélite, visando identificar as maiores diferenças entre as áreas construídas vetorizada e as áreas construídas cadastradas, para orientar a fiscalização 
e os levantamentos de campo. A diferença das áreas construídas observada entre a base cartográfica vetorizada e o cadastro imobiliário oficial foi utilizada apenas como subsídio para apontar os imóveis a serem visitados pelas equipes de campo, constituídas por profissionais competentes, habilitados a realizar a fiscalização dos imóveis e a atualização dos dados do cadastro. Esse método possibilita reduzir os custos dos serviços, indicando apenas os imóveis com maiores probabilidades de se identificar áreas construídas irregulares.

Assim, um dos requisitos do sistema é a utilização de dados atualizados de sensoriamento remoto para a confecção de uma base cartográfica vetorizada que represente a situação real das edificações, permitindo a confrontação das áreas construídas cadastradas e das áreas construídas obtidas por meio do procedimento de vetorização sobre dados do sensoriamento remoto, que se apresentam na forma de imagem. Outro requisito, que se refere ao sistema de informações geográficas enquanto ferramenta operacional para as demandas relativas ao cadastro imobiliário urbano, é a capacidade de atuar como um sistema de banco de dados convencional, possibilitando o armazenamento e a manipulação dos dados, além de fornecer informações a partir de análises baseadas nas estruturas de relacionamentos espaciais.

\subsection{Dados geográficos}

No nível conceitual, a imagem e as geometrias vetorizadas constituem dados geográficos. Os dados geográficos em bancos de dados geográficos 
são compostos por geometrias espaciais, que podem ser expressas em sistemas de coordenadas ou projeção, que são relacionados a dados ou informações alfanuméricas, dados ou informações descritivos. Os dados geográficos, quanto às geometrias espaciais, se diferenciam em tipos: dados temáticos, dados cadastrais, redes, MNTs e imagens ${ }^{6}$.

Os dados temáticos descrevem a distribuição espacial de uma grandeza geográfica, expressa de forma qualitativa. Nos dados cadastrais, cada um dos elementos é um objeto geográfico, que possui atributos e pode estar associado a várias representações gráficas.

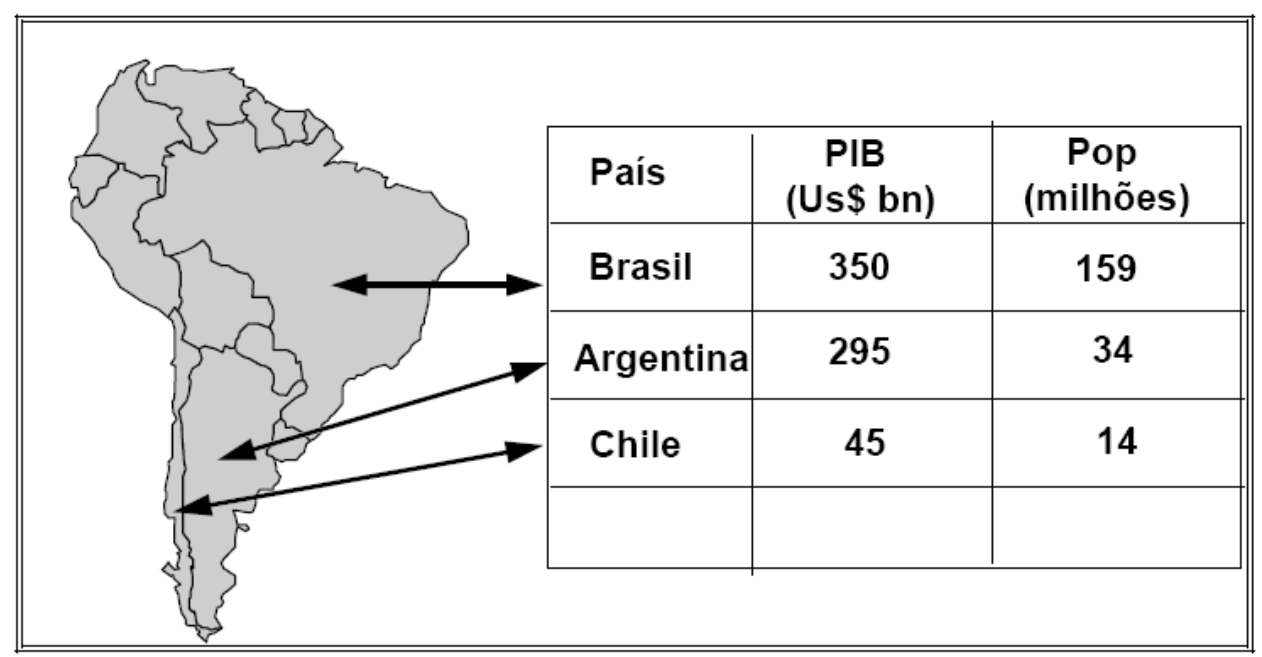

Figura 5 - "Exemplo de mapa cadastral (países da América do Sul)" 7.

${ }^{6}$ CÂMARA, G.; MONTEIRO, A. M. V. Conceitos Básicos em Ciência da Geoinformação. In: CÂMARA, G. et al. Introdução a Ciência da Geoinformação. São José dos Campos, Instituto Nacional de Pesquisas Espaciais - INPE, 2001. Disponível em $<$ http://www.dpi.inpe.br/gilberto/livro/introd/>. 2-25 p.

${ }^{7}$ CÂMARA, G. Modelos, linguagens e arquiteturas para banco de dados geográficos. São José dos Campos. Tese de doutorado em computação aplicada - Instituto Nacional de Pesquisas Espaciais INPE, 1995. Disponível em <http://www.dpi.inpe.br/teses/gilberto/>. 16 e 17 p. 
Nas redes, cada objeto geográfico possui uma localização geográfica exata e está sempre associado a atributos descritivos presentes no banco de dados. As informações gráficas de redes são armazenadas em coordenadas vetoriais, com topologia arco-nó.

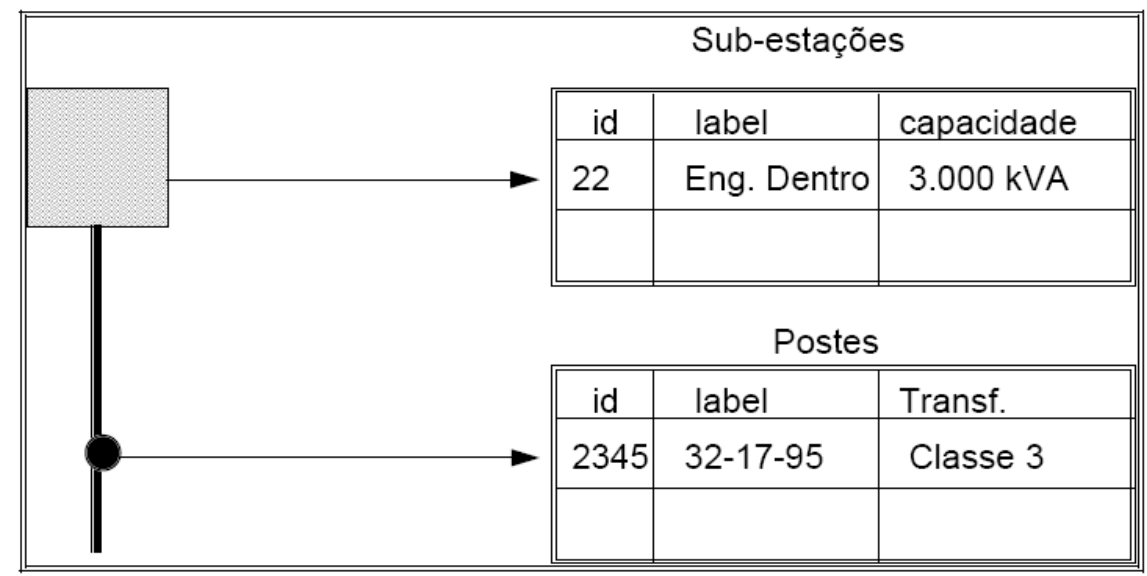

Figura 6 - "Elementos de rede" ${ }^{8}$.

O termo modelo numérico de terreno (MNT) é usado para denotar a representação quantitativa de uma grandeza que varia continuamente no espaço.

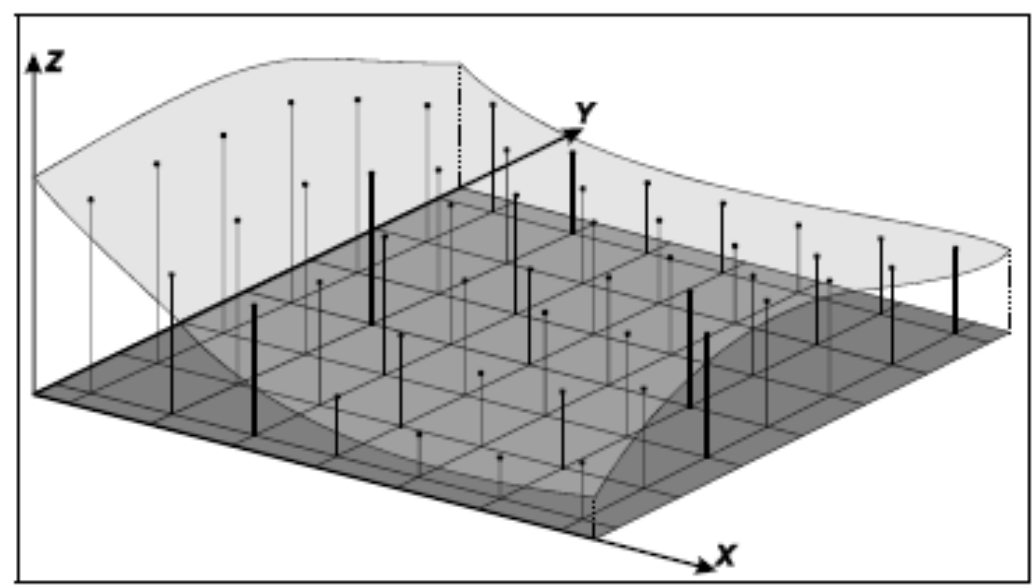

Figura 7 -"Superfície e grade regular correspondente (Fonte: Namikawa, 1995)" ${ }^{9}$. Exemplo de MNT.

${ }^{8}$ CÂMARA, G. Modelos, linguagens e arquiteturas para banco de dados geográficos. São José dos Campos. Tese de doutorado em computação aplicada - Instituto Nacional de Pesquisas Espaciais INPE, 1995. Disponível em <http://www.dpi.inpe.br/teses/gilberto/>. 16 e 17 p. 
As imagens são obtidas por fotografias aéreas ou sensoriamento remoto e representam formas de captura indireta de informação espacial.

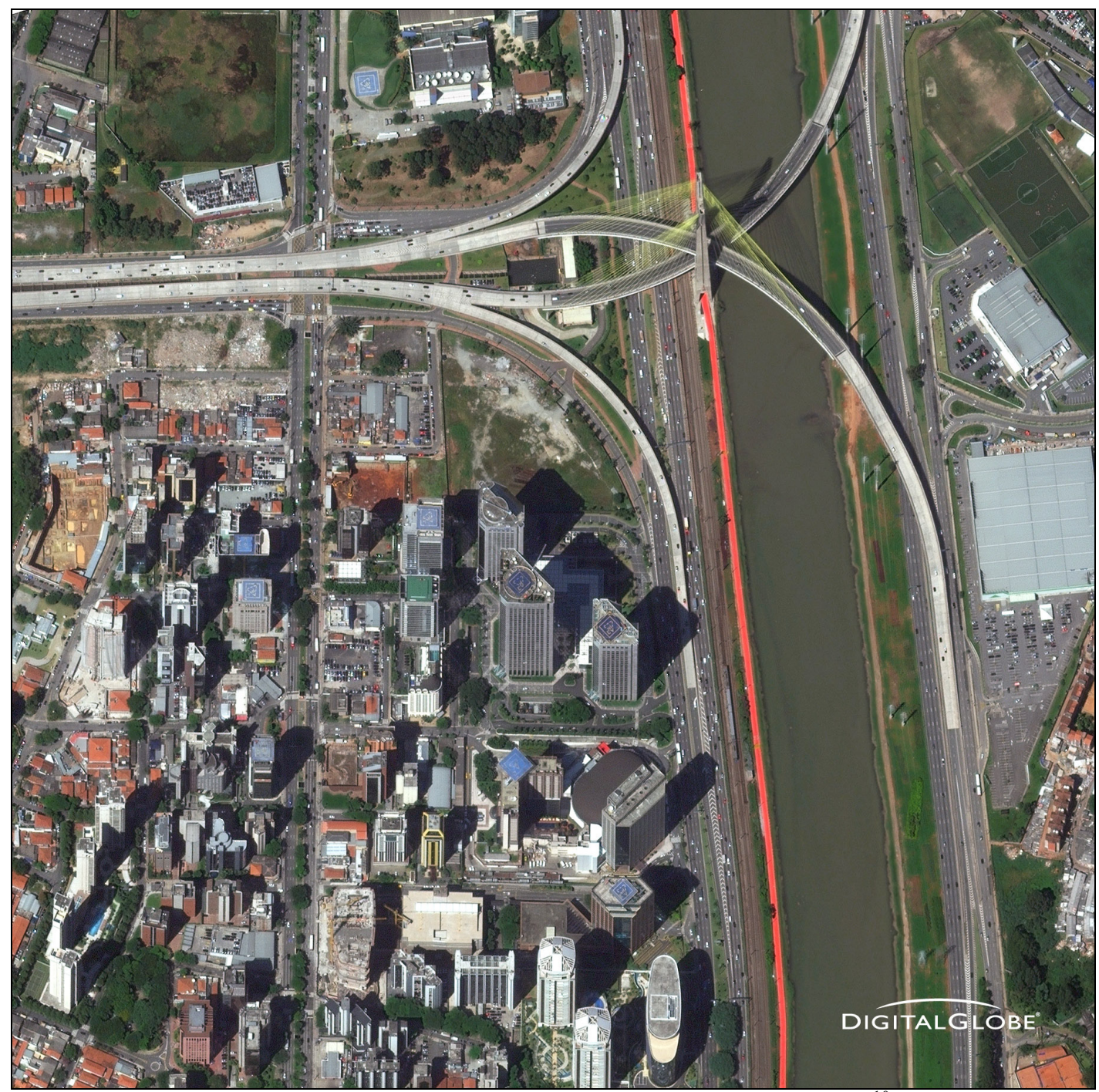

Figura 8 - Exemplo de imagem. WorldView-2, Digital Globe ${ }^{10}$.

${ }^{9}$ CÂMARA, G.; MONTEIRO, A. M. V. Conceitos Básicos em Ciência da Geoinformação. In: CÂMARA, G. et al. Introdução a Ciência da Geoinformação. São José dos Campos, Instituto Nacional de Pesquisas Espaciais - INPE, 2001. Disponível em $<$ http://www.dpi.inpe.br/gilberto/livro/introd/>. 2-27 p.

${ }^{10}$ Disponível em: $<$ http://www.digitalglobe.com>. 
No nível computacional, os dados geográficos podem estar associados a duas grandes classes de representações geométricas: Representação Matricial e Representação Vetorial.

A representação matricial consiste no uso de uma matriz regular quadriculada $\mathrm{P}_{(\mathrm{m}, \mathrm{n})}$, composta de $m$ colunas e $n$ linhas, sobre a qual se constitui, célula a célula (ou pixel a pixel), o elemento a ser representado. $\mathrm{Na}$ representação matricial, o espaço é tratado como uma superfície plana e a resolução do sistema é dada pela relação entre o tamanho da célula e a área por ela coberta na superfície ou terreno.

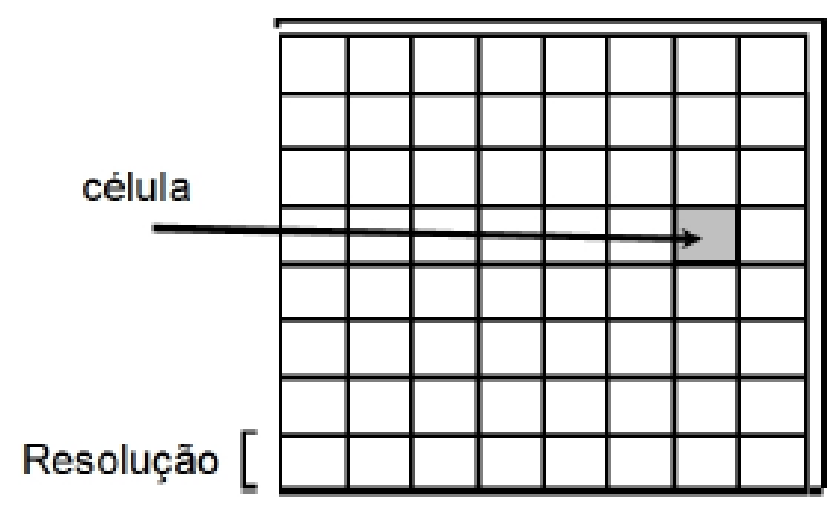

Figura 9 - "Estrutura Matricial" 11.

Cada célula possui um número de linha, um número de coluna e um valor correspondente ao atributo estudado, e pode ser acessada individualmente pelas suas coordenadas. Os dados são codificados em cada célula, atribuindo o

\footnotetext{
${ }^{11}$ CÂMARA, G. et al. Bancos de Dados Geográficos. São José dos Campos, Instituto Nacional de
} Pesquisas Espaciais - INPE, 2005. Disponível em <http://www.dpi.inpe.br/livros/bdados/>. 33 p. 
código correspondente à classe referente ao fenômeno estudado, através de critérios pré-estabelecidos para cada operação.

Os tipo de representação matricial são: Grade Regular (matriz de reais), Imagem em Tons de Cinza, Imagem Temática (representação matricial de um geo-campo temático), Imagem Sintética (imagem em composição colorida em placas gráficas falsa-cor).

Sendo um dos requisitos do sistema a capacidade de identificar os imóveis com maiores possibilidades de conterem áreas edificadas irregulares, deve ser utilizada imagem de satélite com parâmetros apropriados para tais procedimentos. No caso em estudo, foram adquiridas imagens do satélite Quick Bird, georreferenciadas e ortorretificadas, compondo uma cena de $64 \mathrm{~km}^{2}$, correspondente à área urbana da cidade. O satélite Quick Bird possui sensores pancromático e multiespectral, resolução radiométrica de 11 bits, sendo a resolução espacial do sensor pancromático entre 0,61 a 0,72 metros. 


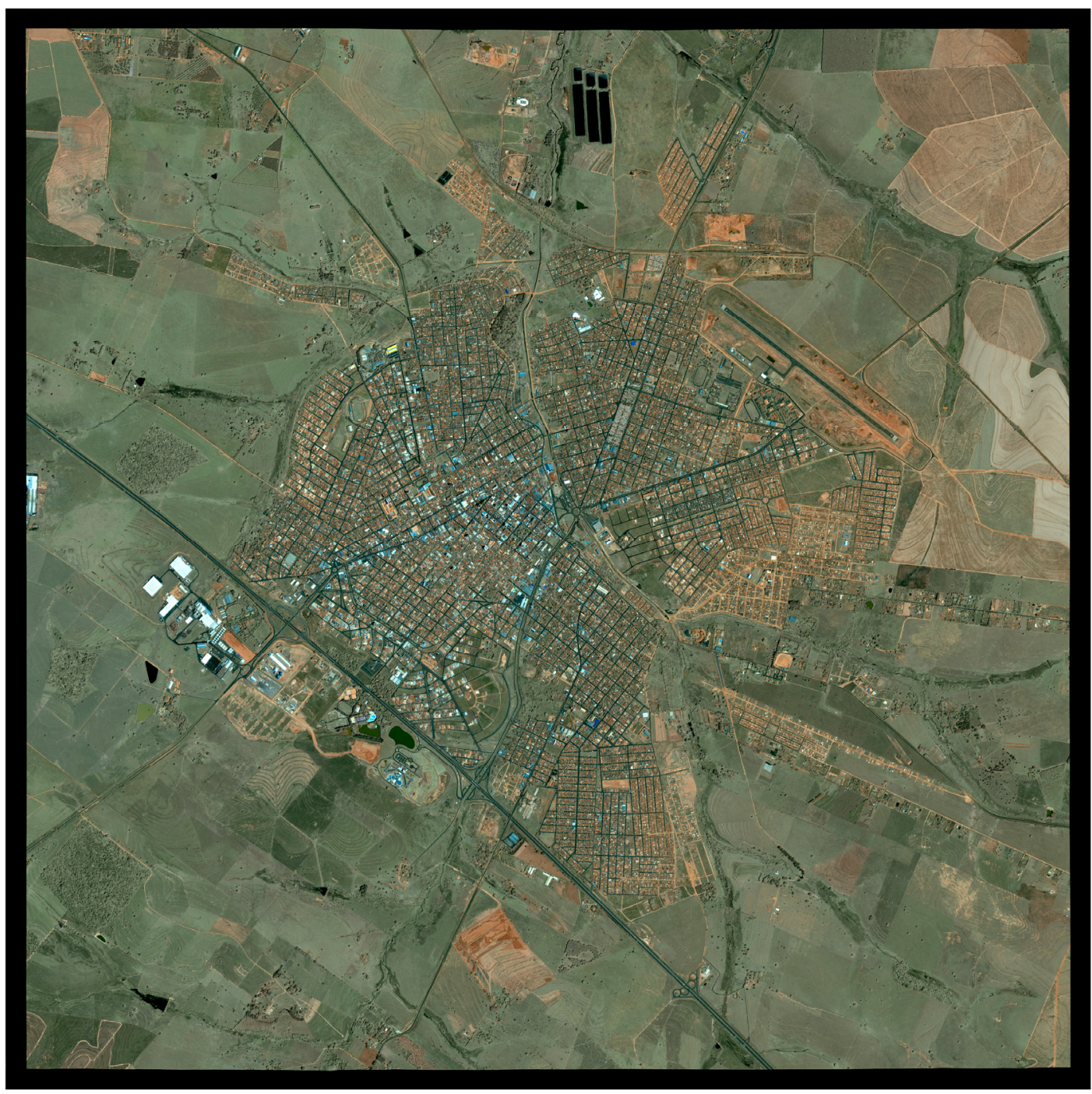

Figura 10 - Imagem do satélite Quick Bird, georreferenciada e ortorretificada, da área urbana do município de Lins (2003). Fonte: BASE Aerofotogrametria e Projetos S. A.

A resolução espacial corresponde às dimensões de um pixel na escala 1:1, portanto, a dimensão do pixel na escala 1:1 do satélite Quick Bird é de no mínimo $0,61 \mathrm{~m}$ e no máximo $0,72 \mathrm{~m}$ e a identificação de limites só é possível para feições com dimensões maiores que a de um pixel em escala 1:1. É um parâmetro importante, pois está diretamente relacionado à identificação visual das feições, essencial para os procedimentos realizados segundo o método adotado, pois determina a precisão das áreas obtidas. 


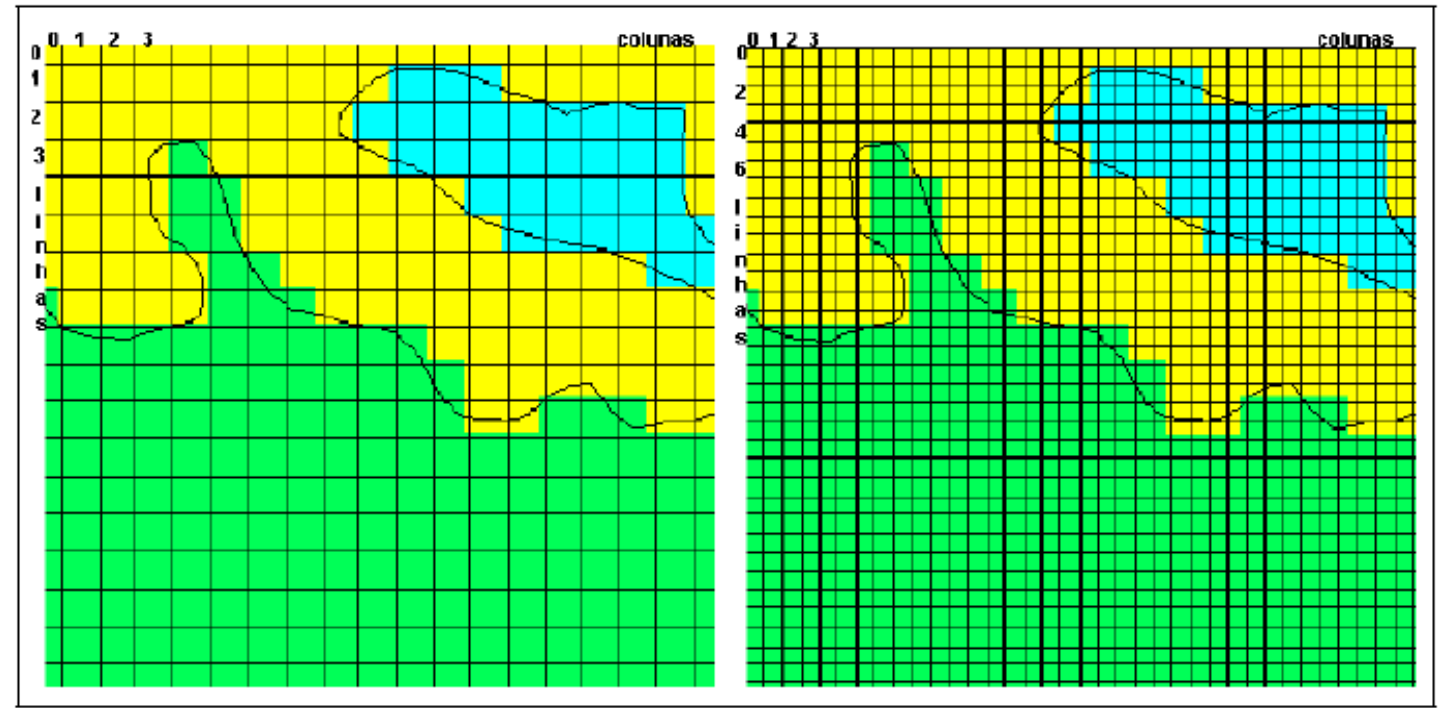

Figura 11 - "Diferentes representações matriciais para um mapa" 12.

A resolução radiométrica determina a quantidade de níveis de intensidade para cada pixel. No caso da resolução radiométrica de 11 bits, cada pixel pode variar até 2.048 níveis de intensidade. A resolução temporal equivale ao período entre duas observações sucessivas do mesmo local, dependendo de características do sensor e da órbita do satélite.

O satélite Quick Bird tem resolução temporal de 1 a 3,5 dias. Por fim, a resolução espectral é a largura da faixa espectral do sistema sensor e determina o comprimento de onda eletromagnética captado, no caso do satélite Quick Bird, compreende o espectro do visível e do infravermelho próximo, possibilitando a identificação visual das feições.

${ }^{12}$ CÂMARA, G.; MONTEIRO, A. M. V. Conceitos Básicos em Ciência da Geoinformação. In: CÂMARA, G. et al. Introdução a Ciência da Geoinformação. São José dos Campos, Instituto Nacional de Pesquisas Espaciais - INPE, 2001. Disponível em

$<$ http://www.dpi.inpe.br/gilberto/livro/introd/>. 2-17 p. 
Tabela 1 - Parâmetros das imagens do satélite Quick Bird ${ }^{13}$

\begin{tabular}{c|l|c|c|c|c}
\hline \multicolumn{1}{c|}{ Sensor } & \multicolumn{1}{|c|}{$\begin{array}{c}\text { Bandas } \\
\text { Espectrais }\end{array}$} & $\begin{array}{c}\text { Resolução } \\
\text { Espectral }\end{array}$ & $\begin{array}{c}\text { Resolução } \\
\text { Espacial }\end{array}$ & $\begin{array}{c}\text { Resolução } \\
\text { Temporal }\end{array}$ & $\begin{array}{c}\text { Resolução } \\
\text { Radiométrica }\end{array}$ \\
\hline Pancromático & Pancromática & $455-900 \mathrm{~nm}$ & $0,61-0,72 \mathrm{~m}$ & & \\
\hline \multirow{3}{*}{ Multiespectral } & Azul & $450-520 \mathrm{~nm}$ & & \multirow{2}{*}{11 a 3,5 dias } & 11 bits \\
\cline { 2 - 3 } & Verde & $520-600 \mathrm{~nm}$ & \multirow{2}{*}{$2,4-2,8 \mathrm{~m}$} & & \\
\cline { 2 - 3 } & Vermelho & $630-690 \mathrm{~nm}$ & & & \\
\cline { 2 - 3 } & $\begin{array}{l}\text { Infravermelho } \\
\text { próximo }\end{array}$ & $760-900 \mathrm{~nm}$ & & & \\
\hline
\end{tabular}

O procedimento de georreferenciamento proporciona maior acurácia no posicionamento de cada pixel da imagem em sistemas de coordenadas ou de projeção. No caso em estudo, foi adotado como sistema de coordenadas geodésicas o SAD69 (South American Data 1969) e o elipsóide de referência UGGI67 (União Geodésica e Geofísica Internacional 1967) e o sistema de projeção UTM (Universal Transversa de Mercator), sistemas recomendados pelo IBGE (Instituto Brasileiro de Geografia e Estatística). O procedimento de ortorretificação oferece maior precisão nas dimensões e nas proporções das feições presentes na imagem, pois consiste na redução das deformações resultantes dos efeitos óticos, da topografia do terreno, da direção da visada, entre outras interferências, através da aplicação de modelo matemático ou de função de interpolação tridimensional para correção geométrica, aproximando a imagem de uma projeção ortogonal do terreno.

O georreferenciamento e a ortorretificação da imagem são requisitos importantes para a sua utilização como base para a identificação de áreas de feições, além disso, possibilita uma grande diversidade de aplicações para fins relativos ao posicionamento geográfico. No nível conceitual, tais requisitos se

\footnotetext{
${ }^{13}$ Disponível em: <http://www.sat.cnpm.embrapa.br/conteudo/quickbird.htm>.
} 
relacionam com o conceito de região geográfica, definida como uma superfície qualquer pertencente ao espaço geográfico, que pode ser representada em um plano ou reticulado, dependente de uma projeção cartográfica e que constitui suporte geométrico para a localização de entidades geográficas.

Câmara \& Monteiro (2001) afirmam que, no modelo de representação, ou estrutura, vetorial, a localização e a aparência gráfica de cada objeto são representadas por um ou mais pares de coordenadas. Sistemas CAD e outros tipos de sistemas gráficos também utilizam representações vetoriais, porém o uso de vetores em SIG é mais sofisticado que o uso em CAD, pois possui recursos para tratamento de topologia, associação de atributos alfanuméricos e indexação espacial.

Além disso, Câmara et al (2005) explica:

"As estruturas vetoriais são utilizadas para representar as coordenadas das fronteiras de cada entidade geográfica, através de três formas básicas: pontos, linhas e áreas (ou polígonos), definidas por suas coordenadas cartesianas..." (Câmara et al, 2005, p.25).

Portanto, na representação vetorial, onde são representadas as fronteiras dos objetos em duas dimensões, consideram-se três elementos gráficos: ponto, linha poligonal e polígono. 


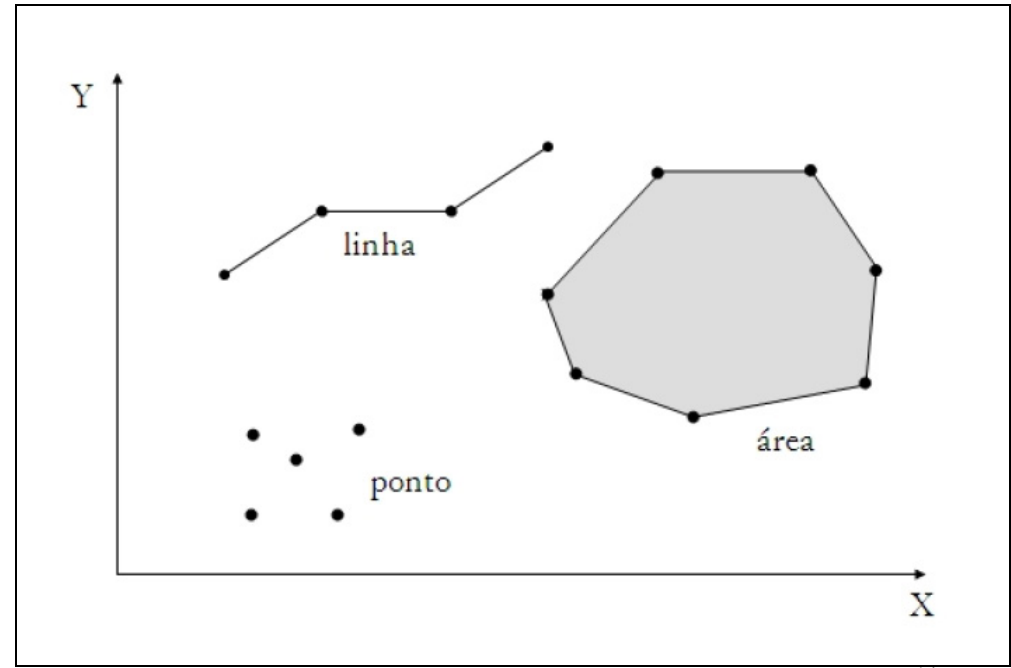

Figura 12 - "Representações vetoriais em duas dimensões." ${ }^{14}$.

Os conceitos de espaço absoluto e espaço relativo são importantes para a compreensão dos diferentes modelos e representações para dados geográficos. Esta distinção decorre da possibilidade se representar a localização dos objetos no espaço ou apenas a o posicionamento relativo entre eles.
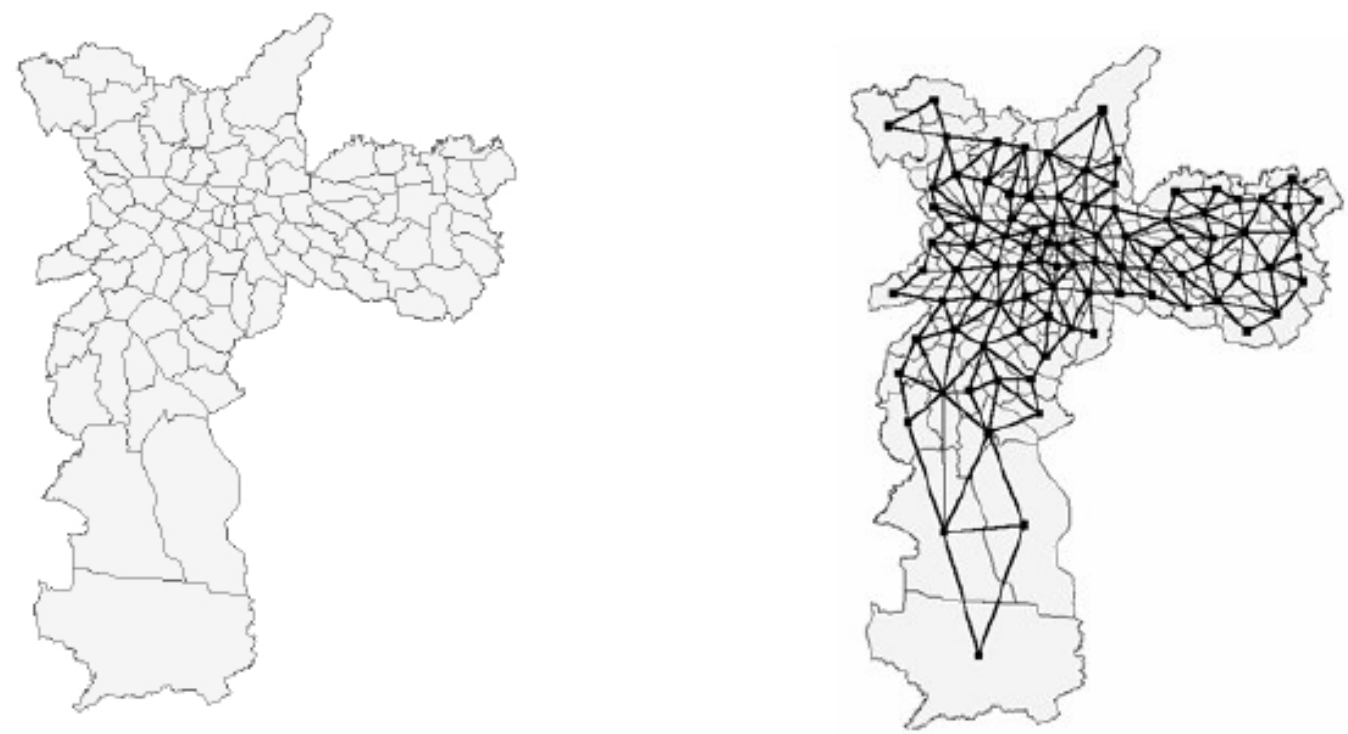

Figura 13 - "Dualidade entre espaço absoluto e espaço relativo. À esquerda, distritos de São Paulo com suas fronteiras. À direita grafo mostrando a rede de conectividade entre os distritos (espaço relativo). O mapa da esquerda foi repetido por razões de maior legibilidade" ${ }^{15}$.

${ }^{14}$ CÂMARA, G. et al. Bancos de Dados Geográficos. São José dos Campos, Instituto Nacional de Pesquisas Espaciais - INPE, 2005. Disponível em <http://www.dpi.inpe.br/livros/bdados/>. 25 p. 
Os tipos de representação vetorial se determinam pelas primitivas geométricas vetoriais e representações topológicas que caracterizam os elementos. A topologia se refere ao relacionamento espacial das feições e é definida como a parte da matemática que estuda as propriedades geométricas que não variam mediante uma deformação. Assim, formas e coordenadas dos objetos não interferem na estrutura do modelo topológico. A topologia proporciona o processamento de funções analíticas como a modelagem do fluxo através das linhas conectadas de uma rede, combinação de polígonos adjacentes e sobreposição de feições geométricas.

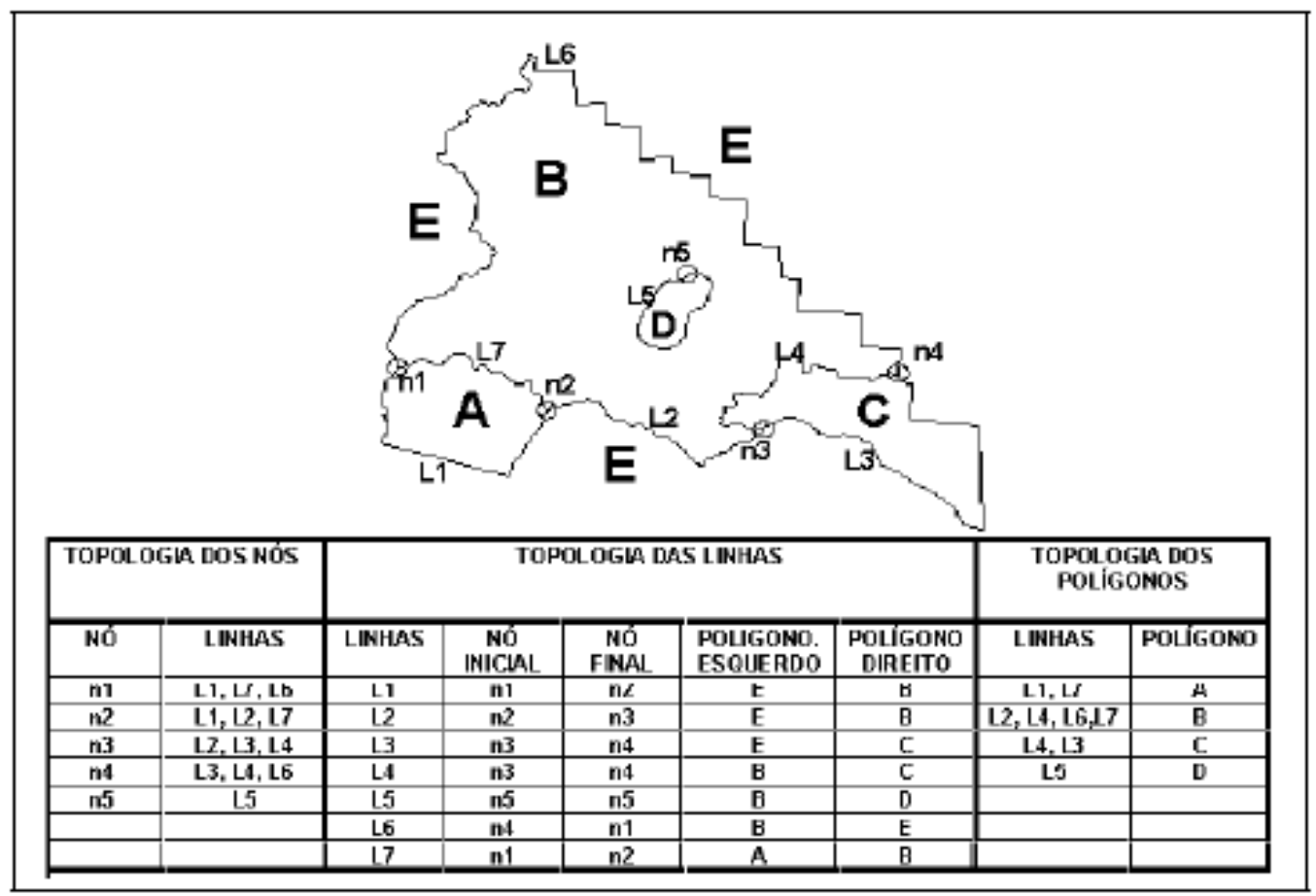

Figura 14 - "Estrutura topológica do tipo arco-nó-polígono"16.

\footnotetext{
${ }^{15}$ CÂMARA, G. et al. Bancos de Dados Geográficos. São José dos Campos, Instituto Nacional de Pesquisas Espaciais - INPE, 2005. Disponível em <http://www.dpi.inpe.br/livros/bdados/>. 18 p. ${ }^{16}$ CÂMARA, G.; MONTEIRO, A. M. V. Conceitos Básicos em Ciência da Geoinformação. In: CÂMARA, G. et al. Introdução a Ciência da Geoinformação. São José dos Campos, Instituto Nacional de Pesquisas Espaciais - INPE, 2001. Disponível em $<$ http://www.dpi.inpe.br/gilberto/livro/introd/>. 2-22 p.
} 
A comparação entre as representações matricial e vetorial, ainda que especificamente para mapas temáticos, é exemplificada nas referências a seguir:

Tabela 2 - Comparação entre estruturas vetoriais e matriciais para mapas temáticos

\begin{tabular}{l|l|l}
\hline Aspecto & Vetorial & Matricial \\
\hline Armazenamento & Por coordenadas (mais eficiente) & $\begin{array}{l}\text { Requer mais espaço de } \\
\text { armazenamento }\end{array}$ \\
\hline Algoritmos & $\begin{array}{l}\text { Problemas com erros } \\
\text { geométricos }\end{array}$ & $\begin{array}{l}\text { Processamento mais rápido e } \\
\text { eficiente }\end{array}$ \\
\hline Escala de trabalho & $\begin{array}{l}\text { Adequado tanto a grandes } \\
\text { quanto a pequenas escalas }\end{array}$ & $\begin{array}{l}\text { Mais adequado para pequenas } \\
\text { escalas (1:25.000 e menores) }\end{array}$ \\
\hline $\begin{array}{l}\text { Análise, Simulação e } \\
\text { Modelagem }\end{array}$ & $\begin{array}{l}\text { Representação indireta de } \\
\text { fenômenos contínuos } \\
\text { Álgebra de mapas é limitada }\end{array}$ & $\begin{array}{l}\text { Representa melhor fenômenos } \\
\text { com variação contínua no espaço } \\
\text { Simulação e modelagem mais } \\
\text { fáceis }\end{array}$ \\
\hline
\end{tabular}

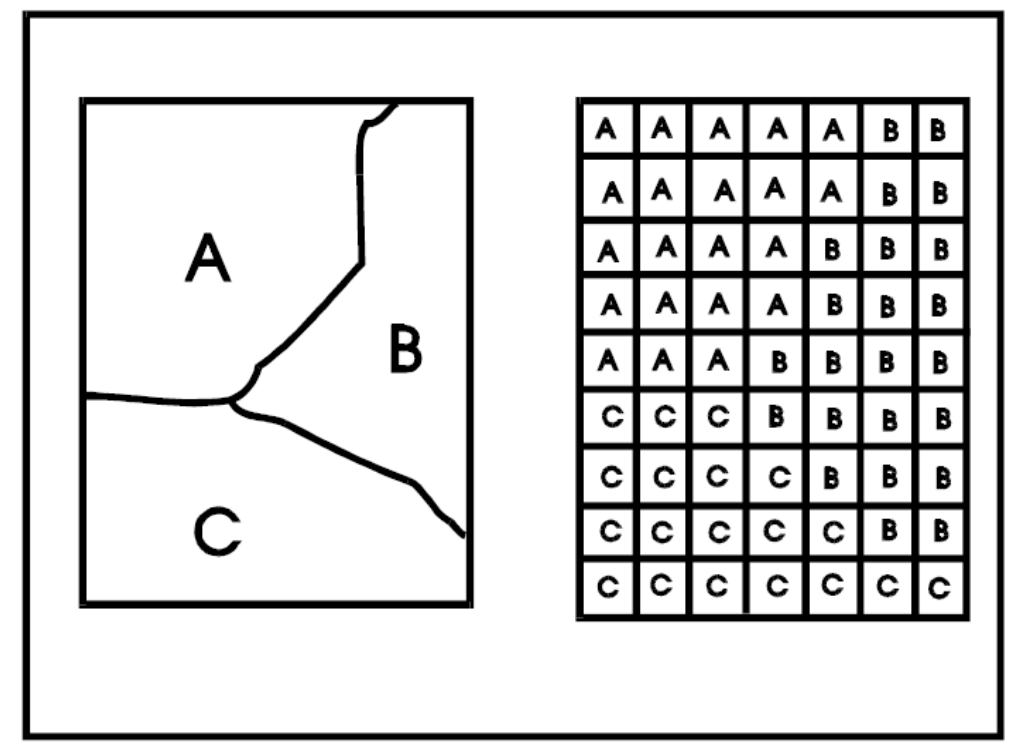

Figura 15 - "Representação vetorial e matricial de um mapa temático" 17.

A imagem utilizada no caso em estudo, portanto, constitui referência e base para a vetorização das geometrias que integram o banco de dados

${ }^{17}$ CÂMARA, G.; MONTEIRO, A. M. V. Conceitos Básicos em Ciência da Geoinformação. In: CÂMARA, G. et al. Introdução a Ciência da Geoinformação. São José dos Campos, Instituto Nacional de Pesquisas Espaciais - INPE, 2001. Disponível em $<$ http://www.dpi.inpe.br/gilberto/livro/introd/>. 2-25 p. 
geográfico. Não obstante a utilização de dados de sensoriamento remoto, de representação matricial, o modelo cadastral de dados geográficos, com representação vetorial, atende mais eficientemente aos requisitos exigidos em cadastros imobiliários, dentre os quais se destacam: a necessidade de comportar dados e informações descritivas vinculadas às feições espaciais; permitir operações de atualização e modificação dos dados e informações, inclusive no que diz respeito ao seu relacionamento e a organização; e delimitação clara dos objetos representados.

Uma vez que o sistema tem como objetivo a identificação de áreas construídas não regularizadas, com vistas à sua regularização e conseqüente atualização cadastral, deve ter base de dados composta de dados oficiais. Assim, a vetorização de quadras, lotes e logradouros não pode ser realizada exclusivamente com base na imagem de satélite, já que esta não reflete os dados oficiais do cadastro e, por vezes, não permite identificar as divisas de lotes, logradouros ou mesmo quadras. A representação de quadras, lotes e logradouros, ou outros elementos que identifiquem e individualizem um imóvel, em um sistema de informações geográficas voltado para a gestão do cadastro imobiliário municipal, resulta em uma base cartográfica composta de geometrias oficiais, baseada em plantas de loteamentos aprovados, plantas-quadra, boletim de informação cadastral (BIC), ou outros documentos oficiais que permitam realizar o cadastramento. Tal procedimento corrobora com a adoção do modelo vetorial para constituição da representação espacial do banco de dados geográfico. No caso em estudo, foram utilizadas as chamadas plantas-quadra, as plantas de loteamentos aprovados e os Boletins de 
Informações Cadastrais para a composição, sobre a imagem de satélite, da base cartográfica.

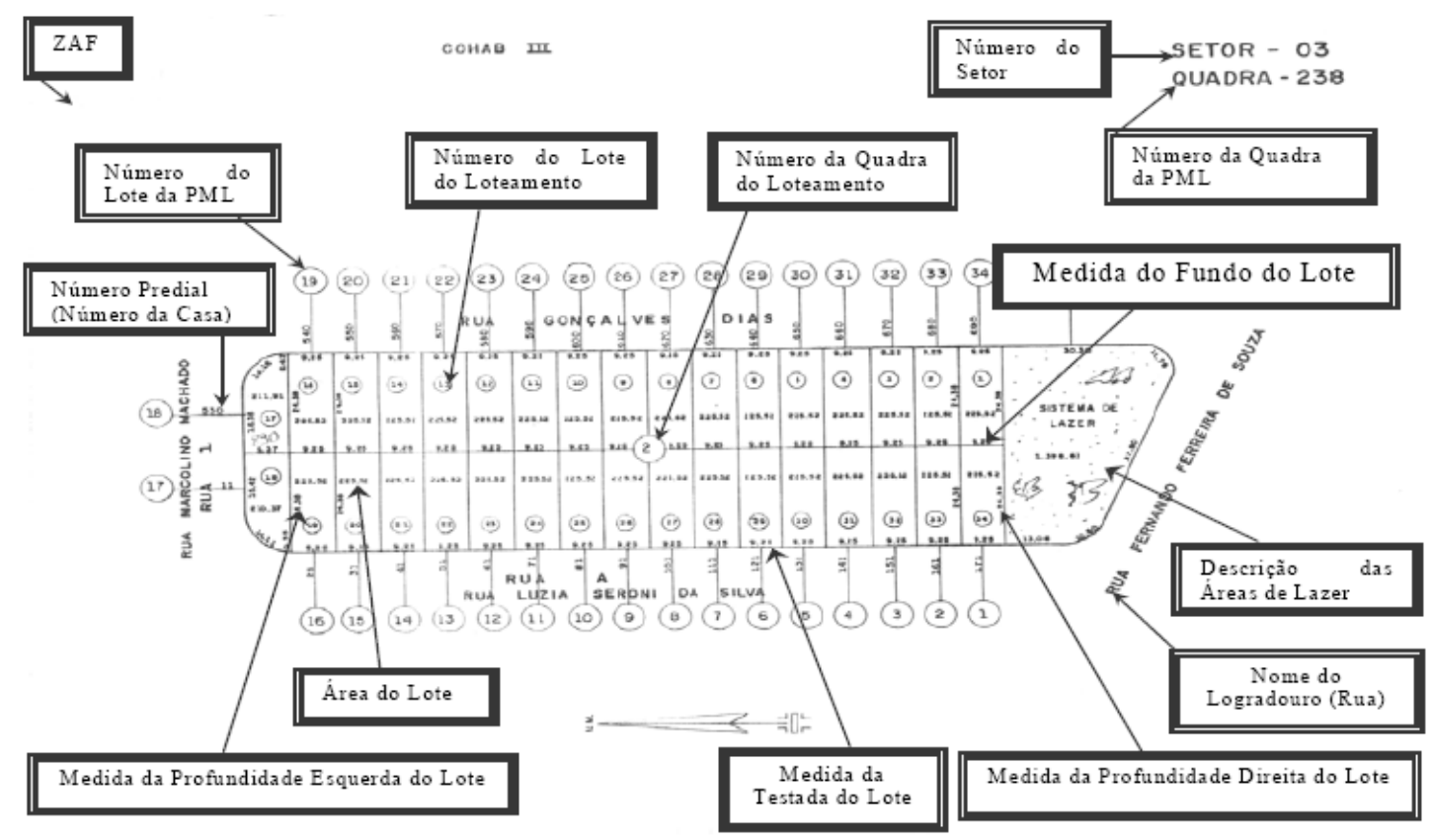

Figura 16 - Planta-quadra com indicação dos dados e informações. Fonte: Prefeitura Municipal de Lins. Elaborado por: Fundação Paulista de Tecnologia e Educação - Centro de Tecnologia em Geoprocessamento.

Por outro lado, o método adotado pretende apontar áreas construídas não regularizadas, de modo que a identificação e vetorização das edificações foi feita diretamente sobre a imagem de satélite, buscando refletir as áreas construídas reais dos imóveis urbanos, para confrontar com os dados oficiais do cadastro imobiliário. Como o sistema tem como referência uma imagem de satélite georreferenciada e ortorretificada é possível estimar a área construída das edificações, adicionada ao banco de dados na forma de novo atributo (“área geo”) da entidade Lote, para confrontar com as áreas cadastradas oficiais. 
Assim, no método adotado para o caso estudado, sobre a imagem de satélite procedeu-se a vetorização das representações das entidades integrantes do banco de dados geográfico, utilizando o software AutoCAD, incluindo as geometrias de quadras, lotes, logradouros, Zonas de Abrangência Fiscal, setores, piscinas, canteiros, ferrovias, hidrografias, obras de arte, entre outras.

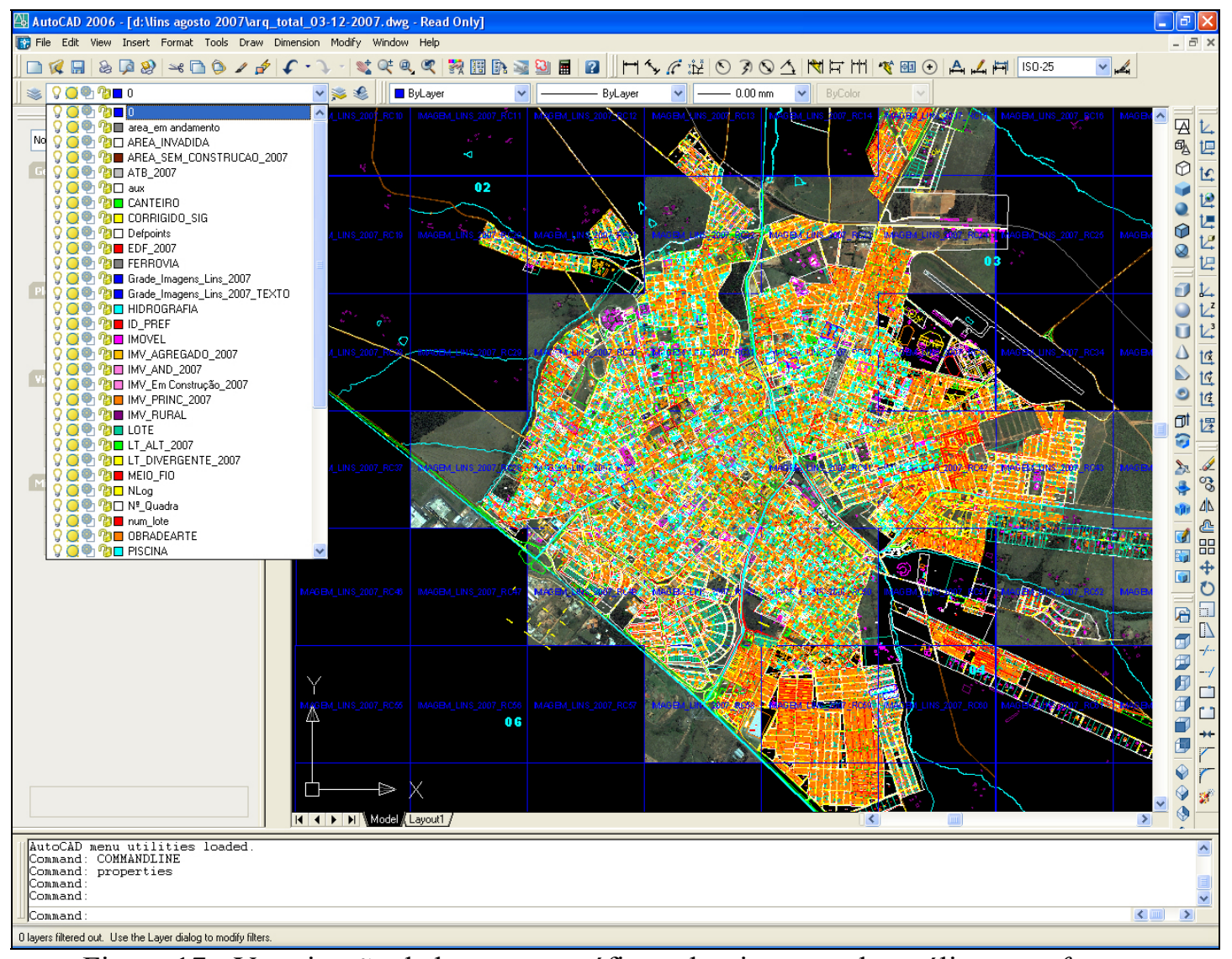

Figura 17 - Vetorização da base cartográfica sobre imagem de satélite no software AutoCAD.

\subsection{Entidades}

A definição das entidades e, consequentemente, dos objetos e feições a serem vetorizados, bem como de seus atributos e relacionamentos, depende dos modelos adotados para tal finalidade. Nos modelos conceituais para entidades, 
no espaço absoluto, os dados geográficos são definidos a partir de modelos de campos (geo-campos) ou de objetos (geo-objetos).

"Um geo-campo representa a distribuição espacial de uma variável que possui valores em todos os pontos pertencentes a uma região geográfica, num dado tempo t" (Câmara \& Monteiro, 2001, p. 2-13).

Segundo Câmara, um geo-campo pode ser temático, quando associa a cada ponto do espaço um tema; numérico, quando associa a cada ponto do espaço um valor numérico; ou dado de sensor remoto, que é uma especialização do numérico, obtido através da discretização da resposta recebida por um sensor.

"Um geo-objeto é um elemento único que possui atributos não espaciais e está associado a múltiplas localizações geográficas. A localização pretende ser exata e o objeto é distinguível de seu entorno." (Câmara \& Monteiro, 2001, p. 2-14).

O modelo de objetos representa o espaço geográfico como uma coleção de entidades distintas e identificáveis. 

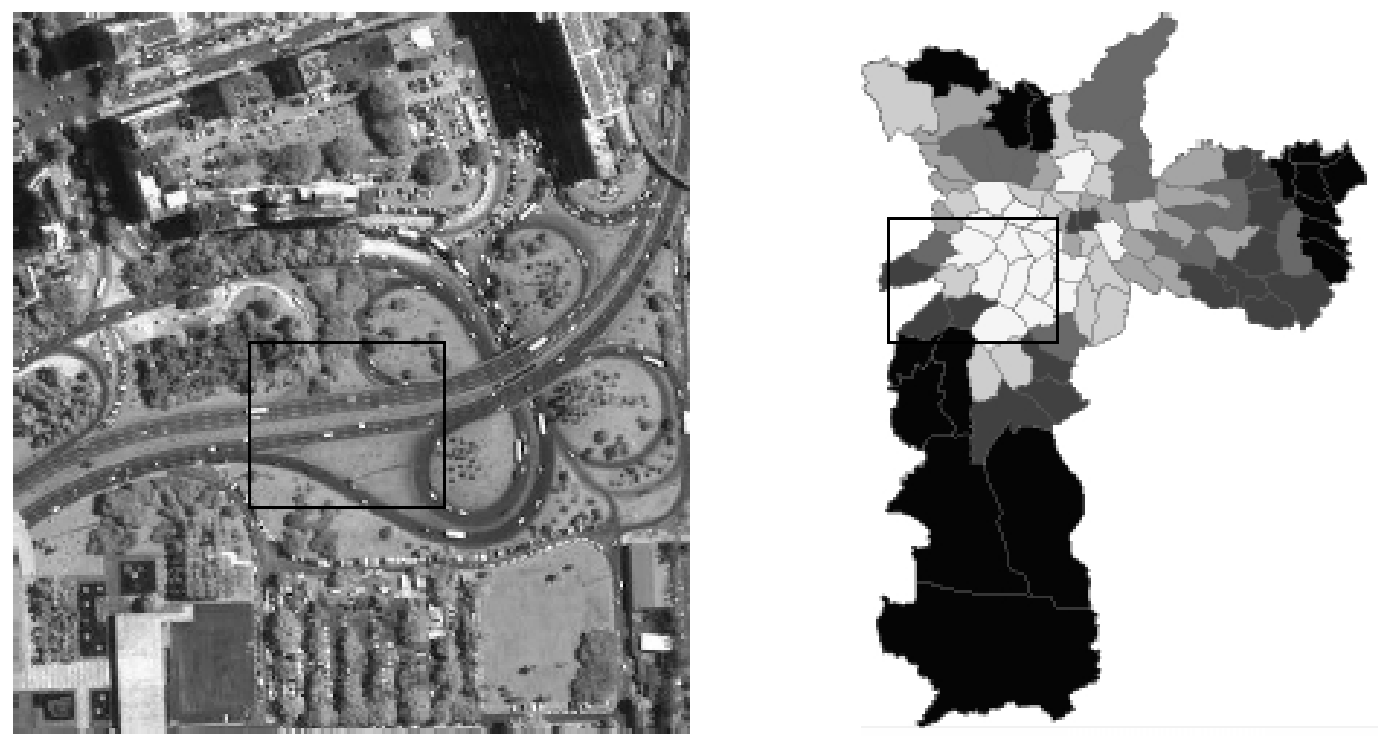

Figura 18 - "Exemplo de geo-campo (imagem IKONOS do Rio de Janeiro) e de conjunto de geoobjetos (distritos da cidade de São Paulo)" ${ }^{18}$.

Os modelos contemplam ainda o objeto não-espacial, que não possui localizações espaciais associadas e engloba qualquer tipo de informação que não seja georreferenciada e se queira agregar a um SIG.

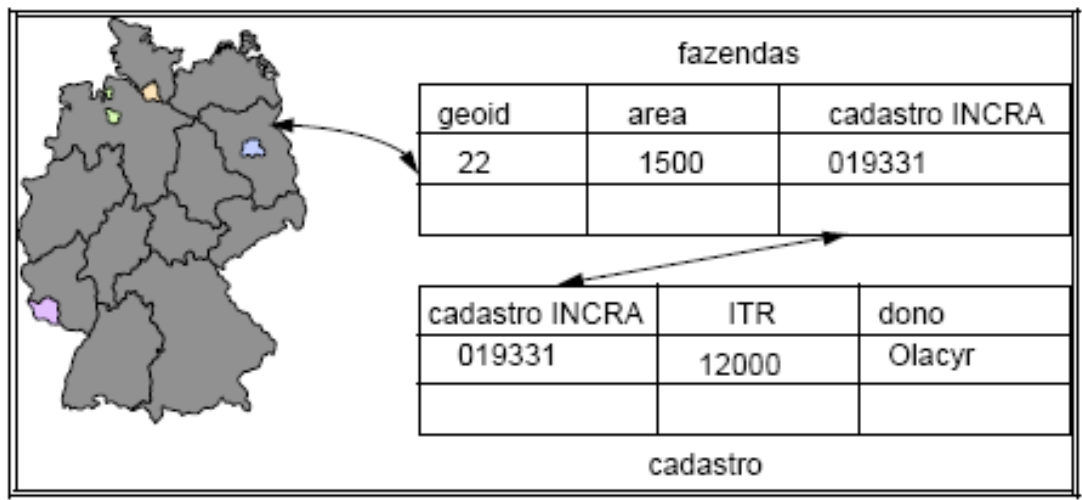

Figura 19 - "Exemplo de ligação entre geo-objeto e objeto não-espacial" ${ }^{19}$.

${ }^{18}$ CÂMARA, G. et al. Bancos de Dados Geográficos. São José dos Campos, Instituto Nacional de Pesquisas Espaciais - INPE, 2005. Disponível em <http://www.dpi.inpe.br/livros/bdados/>. p. 18.

${ }^{19}$ CÂMARA, G. et al. Bancos de Dados Geográficos. São José dos Campos, Instituto Nacional de Pesquisas Espaciais - INPE, 2005. Disponível em <http://www.dpi.inpe.br/livros/bdados/>. 18 p.

${ }^{19}$ CÂMARA, G.; MONTEIRO, A. M. V. Conceitos Básicos em Ciência da Geoinformação. In: CÂMARA, G. et al. Introdução a Ciência da Geoinformação. São José dos Campos, Instituto Nacional de Pesquisas Espaciais - INPE, 2001. Disponível em $<$ http://www.dpi.inpe.br/gilberto/livro/introd/>. 2-16 p. 
Câmara (1995) afirma que, por definição, o modelo de geo-objeto permite a associação de objetos geográficos a diferentes regiões do espaço, sendo conveniente armazenar a representação de um geo-objeto em conjunto com outros da mesma classe, constituindo o conceito de objeto cadastral, como um objeto complexo, que agrupa geo-objetos para uma dada projeção cartográfica e região geográfica.

No caso estudado, o sistema de informações geográficas tem como objetivo a identificação de áreas construídas, implicando, como requisito, na capacidade de realizar procedimentos de consulta para a confrontação dos dados de área construída do cadastro imobiliário oficial existente (oriundos de uma base de dados convencional), com os atributos de área da geometria vetorizada sobre a imagem de satélite. Além disso, tem como objetivo constituir ferramenta computacional para gestão do cadastro imobiliário urbano municipal, possibilitando armazenamento e tratamento de dados.

Nesse mesmo sentido, no espaço relativo, no nível conceitual, o modelo de dados vetorial atende aos requisitos do sistema de possuir a capacidade de representar com precisão os limites dos objetos, as relações topológicas das entidades e seus relacionamentos, bem como de permitir a integração com uma base de dados convencional pré-existente, importada do cadastro imobiliário municipal. Assim, as entidades que integram o banco de dados geográfico são constituídas de dados 
cadastrais, com representação vetorial, constituindo modelos de geo-objeto (objeto cadastral) e de objeto não-espacial.

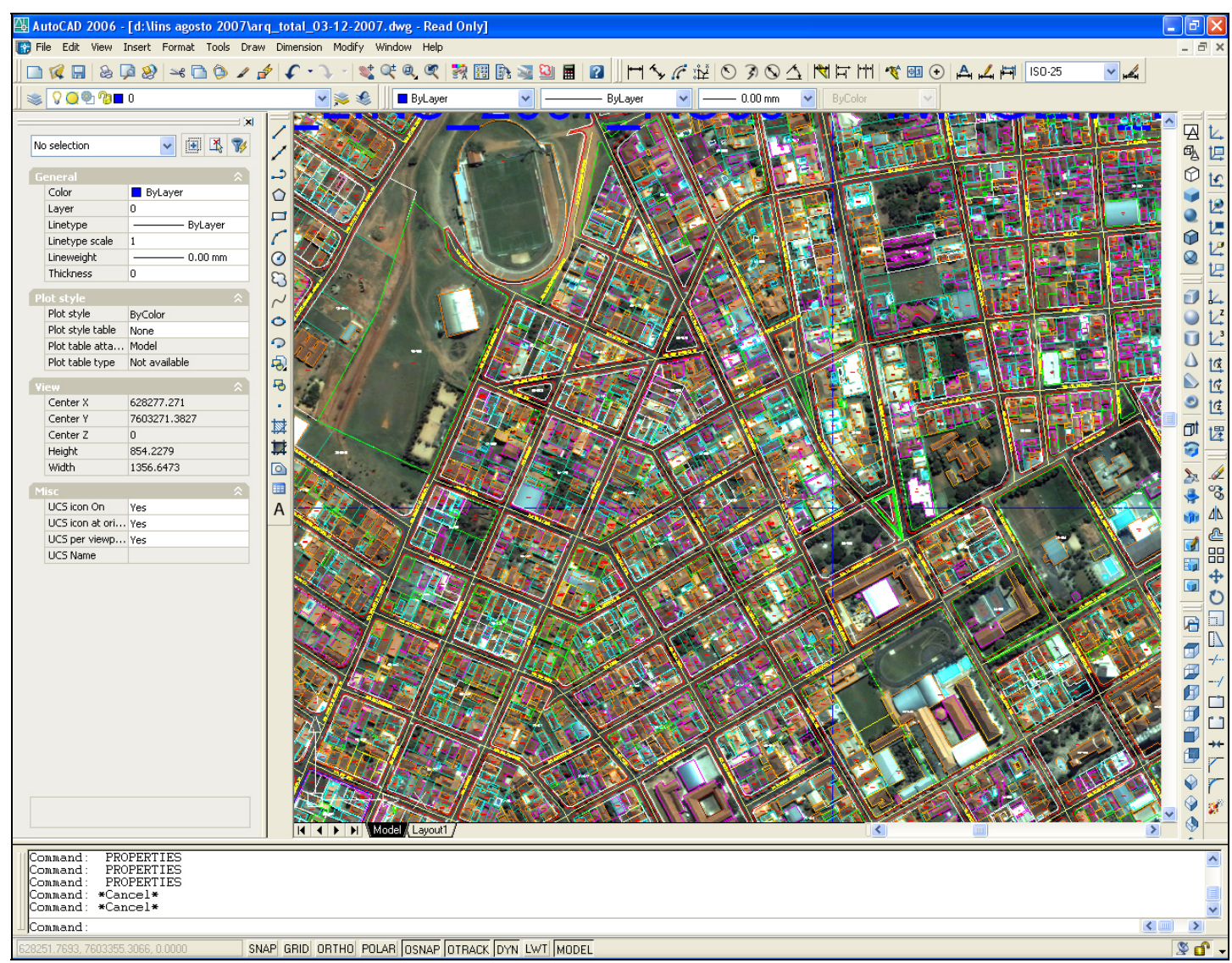

Figura 20 - Vetorização da base cartográfica no software AutoCAD sobre imagem de satélite.

Uma característica do sistema de informações geográficas do caso em estudo, que exemplifica a importância das relações topológicas, é a presença de uma entidade específica para as Zonas de Abrangência Fiscal (ZAFs), que compõem a Planta Genérica de Valores (PGV) municipal e que determinam os valores venais da base de cálculo do IPTU. As ZAFs, representadas com geometria vetorizada, se relacionam com os imóveis que contém, por meio de sua topologia (relação de contingência). 


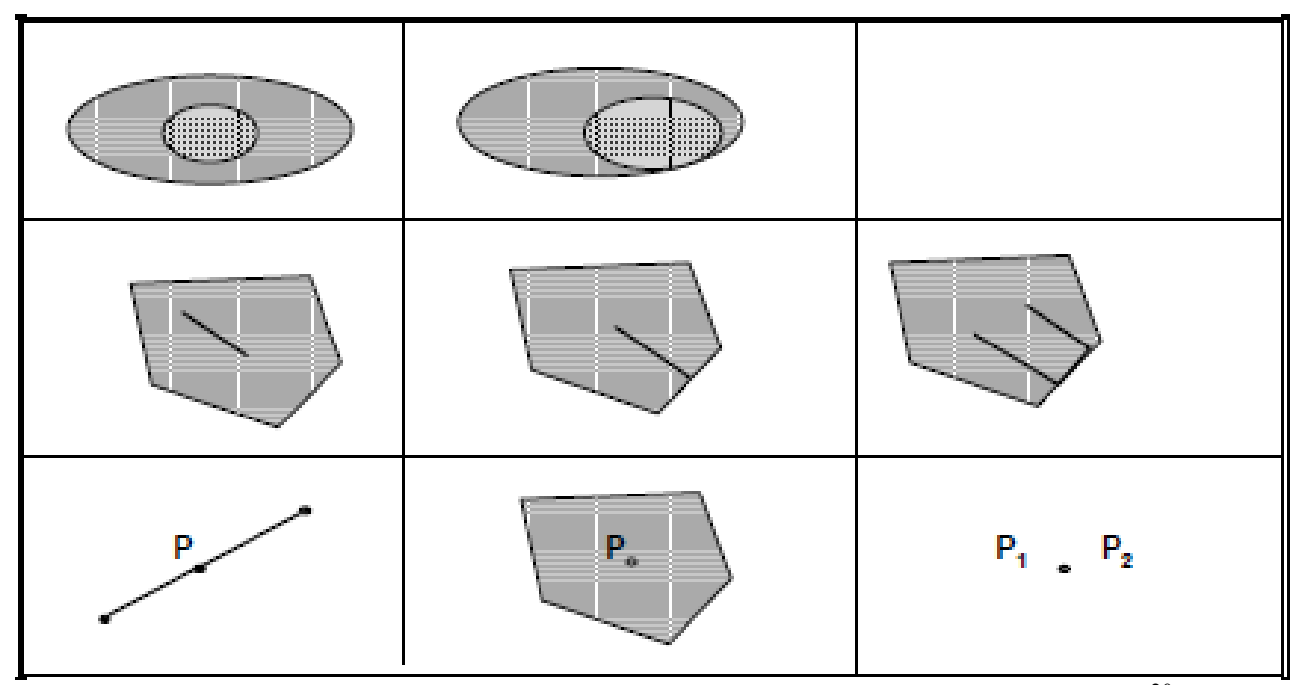

Figura 21 - "Exemplos do relacionamento dentro de (contido em)."."

Assim, o sistema possibilita que a atualização de suas geometrias seja acompanhada pela atualização das ligações lógicas com outras entidades, adequando sua estrutura de acordo com a dinâmica das transformações do sistema. Caso haja uma revisão territorial da Planta Genérica de Valores, uma vez que sejam feitas alterações nas geometrias das ZAFs, poderão ser alterados automaticamente os atributos de valor venal do terreno dos imóveis afetados, evitando que todos os registros do banco de dados tenham que ser atualizados individualmente. Dessa forma, o sistema atende requisitos oriundos da dinâmica das transformações urbanísticas.

Os logradouros também foram definidos como entidade, topologicamente relacionada à entidade de imóvel, evitando problemas comuns de redundância ou falta de padronização, em especial nas operações de busca e seleção.

${ }^{20}$ CÂMARA, G. Modelos, linguagens e arquiteturas para banco de dados geográficos. São José dos Campos. Tese de doutorado em computação aplicada - Instituto Nacional de Pesquisas Espaciais INPE, 1995. Disponível em <http://www.dpi.inpe.br/teses/gilberto/>. 100 p. 
Assim cada imóvel foi relacionado a um logradouro por topologia, impedindo, por exemplo, que imóveis localizados em uma mesma rua tivessem seus nomes cadastrados com diferenças de descrição.

\subsection{Bancos de dados geográficos}

Os bancos de dados geográficos podem se estruturar a partir de diferentes estratégias para a definição da arquitetura do sistema.

"O software que lida com o banco de dados em todos os seus aspectos é denominado comumente de Sistema Gerenciador de Banco de Dados..." (Setzer \& Silva, 2005, p. 12)

Os Sistemas Gerenciadores de Banco de Dados (SGBDs) oferecem serviços de armazenamento, consulta e atualização de bancos de dados e funcionam independentemente dos sistemas aplicativos que utilizam os dados, proporcionando integridade, eficiência e persistência ao sistema.

Cãmara \& Queiroz (2001) ensinam que há basicamente três diferentes arquiteturas de SIGs que utilizam os recursos de um SGBD (Sistema Gerenciados de Banco de Dados): dual, integrada baseada em SGBDs relacionais e integrada baseada em extensões espaciais sobre SGBDs objeto-relacionais. 


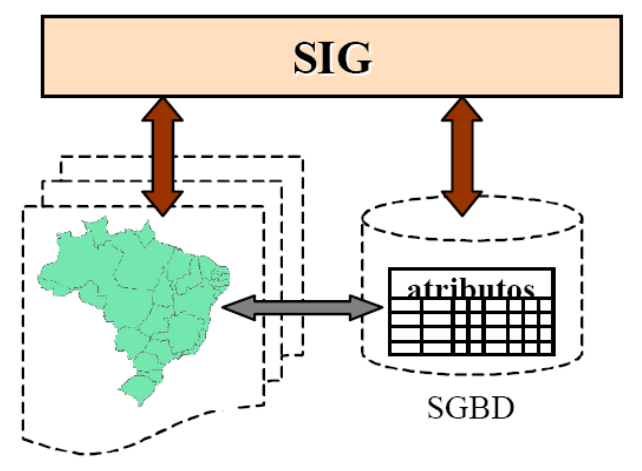

Arquivos

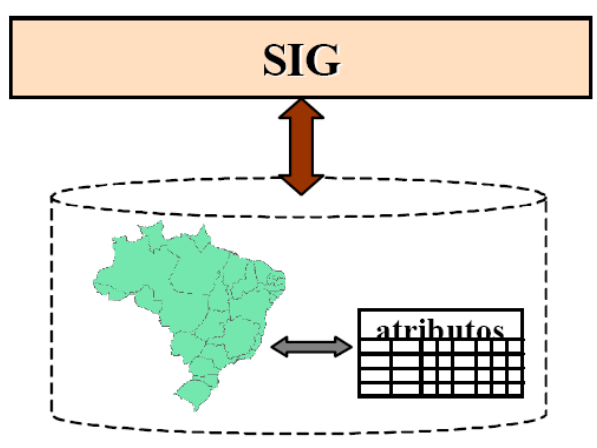

SGBD

Figura 22 - “Arquitetura Dual” e "Arquitetura Integrada". ${ }^{21}$

$\mathrm{Na}$ arquitetura dual utiliza-se um sistema gerenciador de banco de dados relacional (SGBDR) para armazenar os atributos descritivos dos objetos geográficos, e arquivos convencionais para guardar as representações geométricas desses objetos. Um identificador comum liga os componentes geométrico e descritivo do objeto geográfico. Para recuperar um objeto, os dois subsistemas devem ser pesquisados e a resposta é uma composição de resultados. A principal vantagem dessa estratégia é a possibilidade de utilizar SGBDs relacionais de mercado. Por outro lado, uma vez que as representações geométricas dos objetos espaciais não são gerenciados pelo SGBD, há dificuldade para equacionamento de questões como otimização de consultas e controle de integridade.

A arquitetura integrada do sistema pode ser baseada em SGBDs relacionais, que utiliza campos longos, chamados BLOBs (cadeias binárias), para armazenar a componente espacial do dado, ou baseada em extensões espaciais sobre SGBDs objeto-relacionais, que contém funcionalidades e procedimentos que

${ }^{21}$ CÂMARA, G. ; QUEIROZ, G. R. Arquiteturas de Sistemas de Informação Geográfica. In: CÂMARA, G. et al. Introdução a Ciência da Geoinformação. São José dos Campos, Instituto Nacional de Pesquisas Espaciais - INPE, 2001. Disponível em $<$ http://www.dpi.inpe.br/gilberto/livro/introd/>. 3-5 p. 
permitem armazenar, acessar e analisar dados espaciais de formato vetorial. Assim, conforme ensina (camara intrid cap 3 p5) a arquitetura integrada consiste em abranger todo o dado espacial em um SGBD, possibilitando o controle e manipulação de dados espaciais, como gerência de transações, controle de integridade e concorrência.

A adoção de um modelo de banco de dados para a implementação de um sistema de informações geográficas exige a definição de um conjunto de conceitos necessários para descrever a estrutura e as operações nos diferentes níveis de abstração. Esse processo implica na concepção de formas de representação simplificadas da realidade, convenientes para os objetivos e requisitos do sistema.

"A existência de níveis de abstração diferentes permite isolar a análise de um problema do mundo real das questões de implementação física do modelo correspondente”. (Giacaglia, 1998, p.11).

Segundo Borges \& Davis (2001), existem vários tipos de modelos, que podem ser classificados em: modelos de dados conceituais, modelos de dados lógico e modelos de dados físicos. Os modelos conceituais abrangem a semântica do dados, possibilitando a descrição das suas propriedades, no nível conceitual de abstração. Os modelos de dados lógicos descrevem a estrutura de um banco de dados no nível computacional. Os modelos de dados físico são utilizados para descrever as estruturas físicas de armazenamento, no nível interno. 
Os modelos de dados conceituais constituem conjuntos de conceitos que visam descrever as estruturas e operações em banco de dados, de modo a sistematizar o conhecimento sobre os fenômenos e objetos do mundo real representados em sistemas informatizados. Portanto, os modelos de dados conceituais são os mais adequados para representar a semântica dos dados e suas propriedades e são utilizados para proporcionar uma melhor compreensão dos componentes do sistema.

No nível computacional, o modelo lógico para a base de dados pode ser estruturado em rede (e hierárquico) ou baseado no modelo relacional.

O modelo de rede permite que as tabelas sejam utilizadas através do uso de apontadores ou referências (grafos), assim as tabelas se ligam em uma rede de relacionamentos. O modelo hierárquico é uma variação do modelo de redes, com a limitação das relações em uma estrutura de árvore.

No sistema desenvolvido para o estudo de caso, foi adotado o modelo relacional e a arquitetura dual, por se tratar de um grande volume de dados cadastrais a serem gerenciados e por seus requisitos práticos de independência lógica dos dados, possibilitando que os mesmos possam combinados para gerar nova informação, importados de outras bases de dados, exportados para outras bases e utilizados em outras aplicações. 
O modelo relacional é composto basicamente de uma coleção de estruturas de dados (tabelas), uma coleção de operadores, álgebra e cálculos relacionais e uma coleção de restrições de integridade. No modelo relacional, os dados são organizados na forma de tabela onde as linhas correspondem aos registros e as colunas correspondem aos atributos. Neste modelo, toda a informação é apresentada como dado, assim qualquer tipo de atributo representa relações com o conjunto de dados. A ligação lógica entre o dado geográfico e o correspondente dado alfanumérico é feita através de um identificador ou indexador comum, chamado geocodificador, presente tanto no dado geográfico como no descritivo, de forma unívoca.

"Um SIG implementado com estratégia dual utiliza um SGBD relacional para armazenar os atributos convencionais dos objetos geográficos (na forma de tabelas) e arquivos para guardar as representações geométricas desses objetos. " (Câmara \& Monteiro, 2001 p. 2-30).

Decorrente da adoção do modelo relacional, um requisito importante para a definição da metodologia de implantação do sistema é o método de geocodificação, ou seja, de vínculo entre a base geométrica vetorizada e o banco de dados existente, realizável de forma segura e confiável, mas também eficiente e econômica, já que o cadastro imobiliário contém dados de milhares de imóveis. No caso em estudo, para criar as ligações lógicas entre a geometria dos lotes, com seus respectivos dados cadastrais, importados para o banco de dados do sistema, foram utilizadas operações baseadas nas relações topológicas dos objetos. Para tanto foi criada uma entidade representando o código do lote, na forma de texto, e inserido 
dentro dos limites espaciais de cada lote na base cartográfica vetorizada e através de operações topológicas identificou-se cada geometria de lote ao seu respectivo código do lote correspondente entre os dados do cadastro imobiliário.

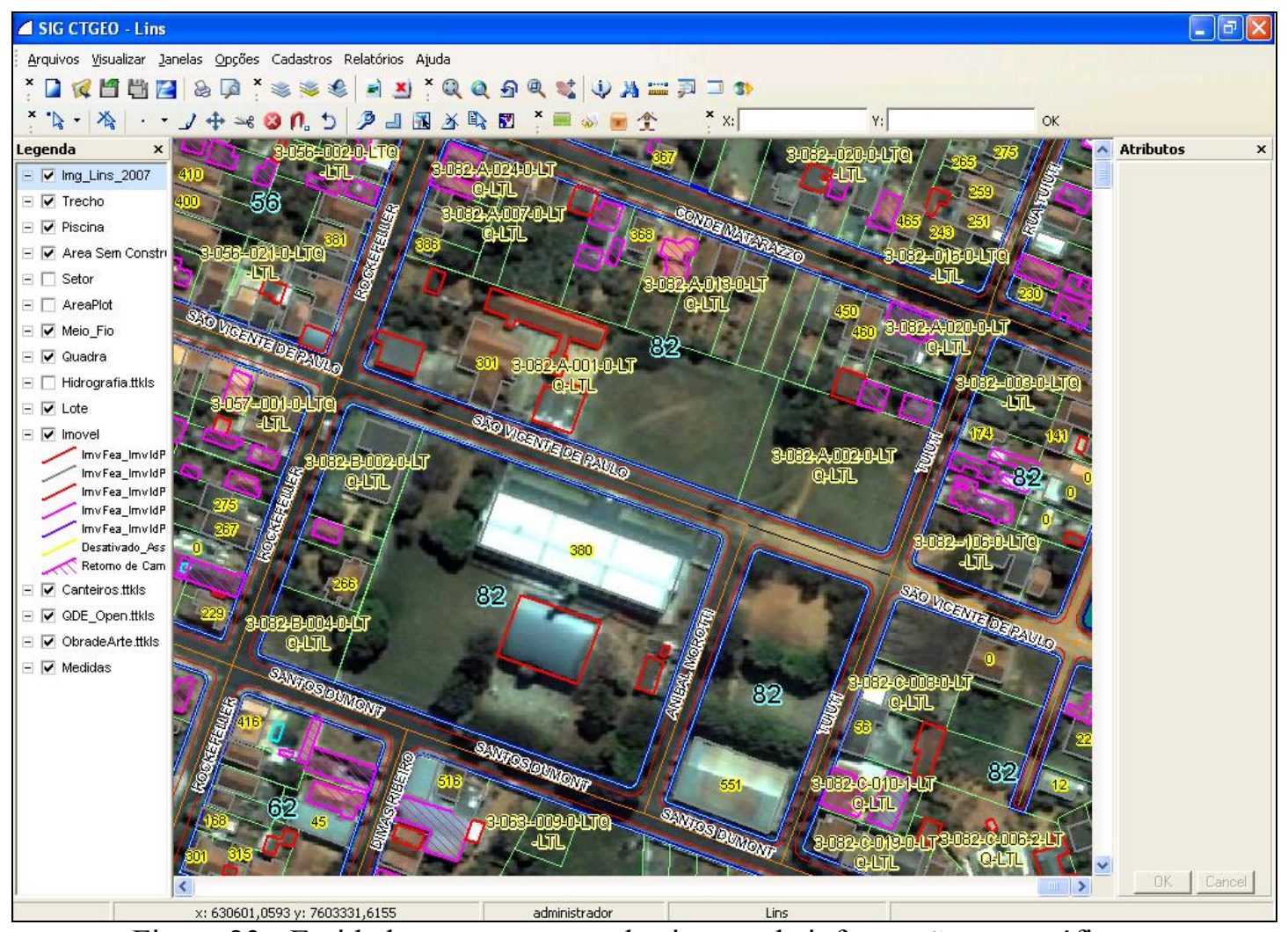

Figura 23 - Entidades componentes do sistema de informações geográficas.

Dessa forma, cada objeto da entidade lote foi relacionado ao seu registro no banco de dados, com seus respectivos atributos, inclusive de área construída aprovada, de forma mais eficiente e segura. Da mesma forma, a área das geometrias das edificações contidas dentro das geometrias dos lotes foi associada ao registro do respectivo lote, porém com um novo atributo chamado de "área geo", com a área obtida da vetorização da imagem de satélite, a ser confrontada com a área construída oficial do cadastro. 
Reforça-se que a área assim obtida pela vetorização contém imprecisões e limitações de uso causadas pelas limitações das resoluções espacial e espectral da imagem, bem como do processo de vetorização (ainda que a imagem seja ortorretificada e georreferenciada) reforçando o propósito do método de apenas indicar as maiores diferenças entre áreas construídas oficiais e áreas obtidas pelo processo de vetorização, embasando os levantamentos de campo.

Segundo a entidade responsável pela implantação do sistema, foi proposto inicialmente, por conhecimento empírico dos responsáveis, que seriam visitados os imóveis que apresentassem no mínimo determinada diferença porcentual entre a área construída cadastrada e a área construída vetorizada sobre a imagem de satélite. Essa porcentagem busca compensar as possíveis diferenças de área ocasionadas pelos processos de aquisição de dados de sensoriamento remoto e de vetorização e variam conforme os métodos e procedimentos adotados. Através de funcionalidades de calculo de valores de atributos e de seleção, o sistema desenvolvido apontou, em mapa e através de relatórios para orientação em campo, os imóveis com áreas construídas vetorizadas maiores tal porcentagem em relação a área construída cadastrada.

Assim, não foi necessário levantar em campo a totalidade dos imóveis urbanos, mas apenas aqueles que, segundo informações obtidas por meio do SIG, apresentaram maiores distorções de área construída, o que representa significativa economia de recursos. A medição dos imóveis em campo foi realizada sob a coordenação de profissionais competentes, legalmente habilitados da 
prefeitura, com a utilização de equipamentos adequados e de acordo com as determinações legais.

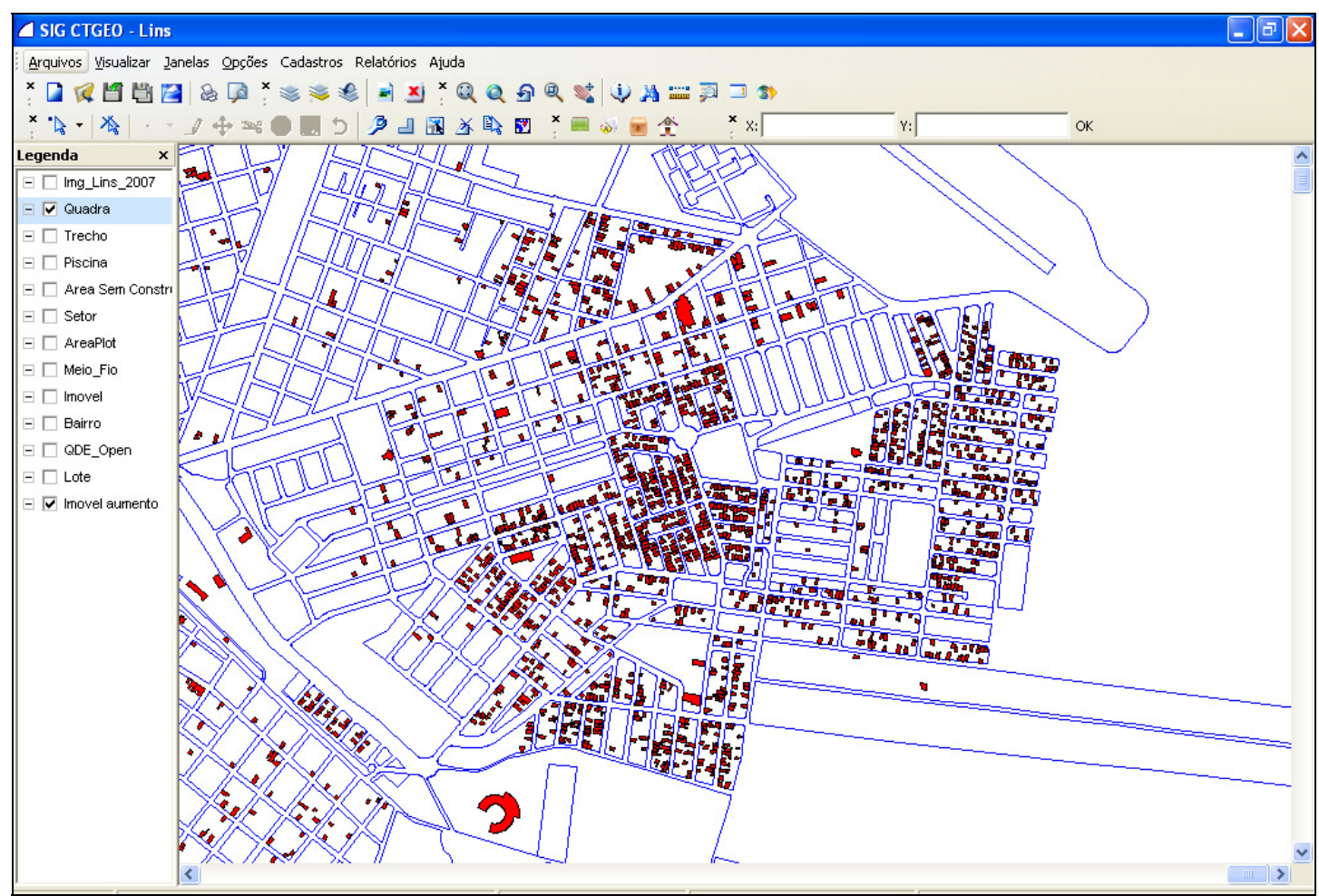

Figura 24 - Mapa dos imóveis a serem vistoriados, obtidos por meio do sistema de informações geográficas. 


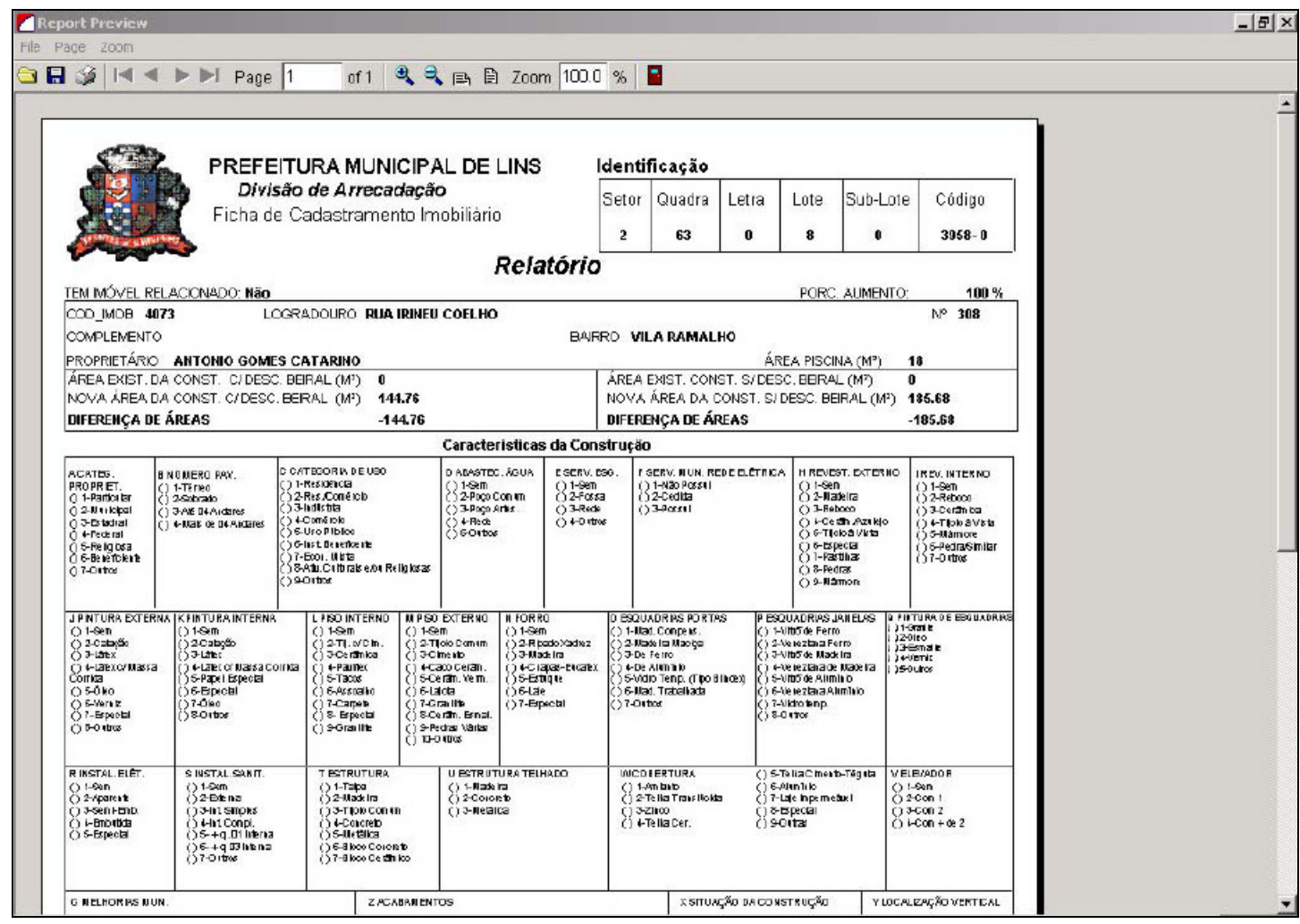

Figura 25 - Relatório gerado pelo sistema de informações geográficas para orientação das visitas em campo, contendo endereço, área cadastrada, área vetorizada, diferença de áreas, padrão de acabamento, entre outras informações pertinentes.

Observou-se que, no caso estudado, dos imóveis apontados pelo sistema, vistoriados e medidos, cerca de $98 \%$ apresentaram de fato aumento de área edificada irregularmente, indicando a eficiência do método adotado para tal finalidade. Além das ampliações de edificações, o sistema identificou imóveis com construções novas sem projeto aprovado e moradias construídas irregularmente em áreas que não lotes (áreas verdes, institucionais, non aedificandi, etc).

Uma vez obtidos os valores das áreas construídas não regularizadas em vistorias e levantamentos de campo, foram atualizados os atributos no cadastro dos imóveis vistoriados. Para tanto, foi desenvolvida para o software uma interface customizada chamada de "tela de cadastro", no sentido de tornar mais 
acessível a utilização do sistema para o cadastramento dos dados e para consultas, abrangendo as operações necessárias, como por exemplo: inclusão e exclusão de dados, edição, alteração, etc., sendo que para cada tipo de operação o sistema exige ou não autorização, de modo a garantir a segurança da base de dados. A elaboração de uma interface acessível é requisito desejável, porém não determina a definição de modelos, mas constitui aplicação que utiliza o banco de dados geográfico e que depende dos modelos adotados na concepção do sistema.

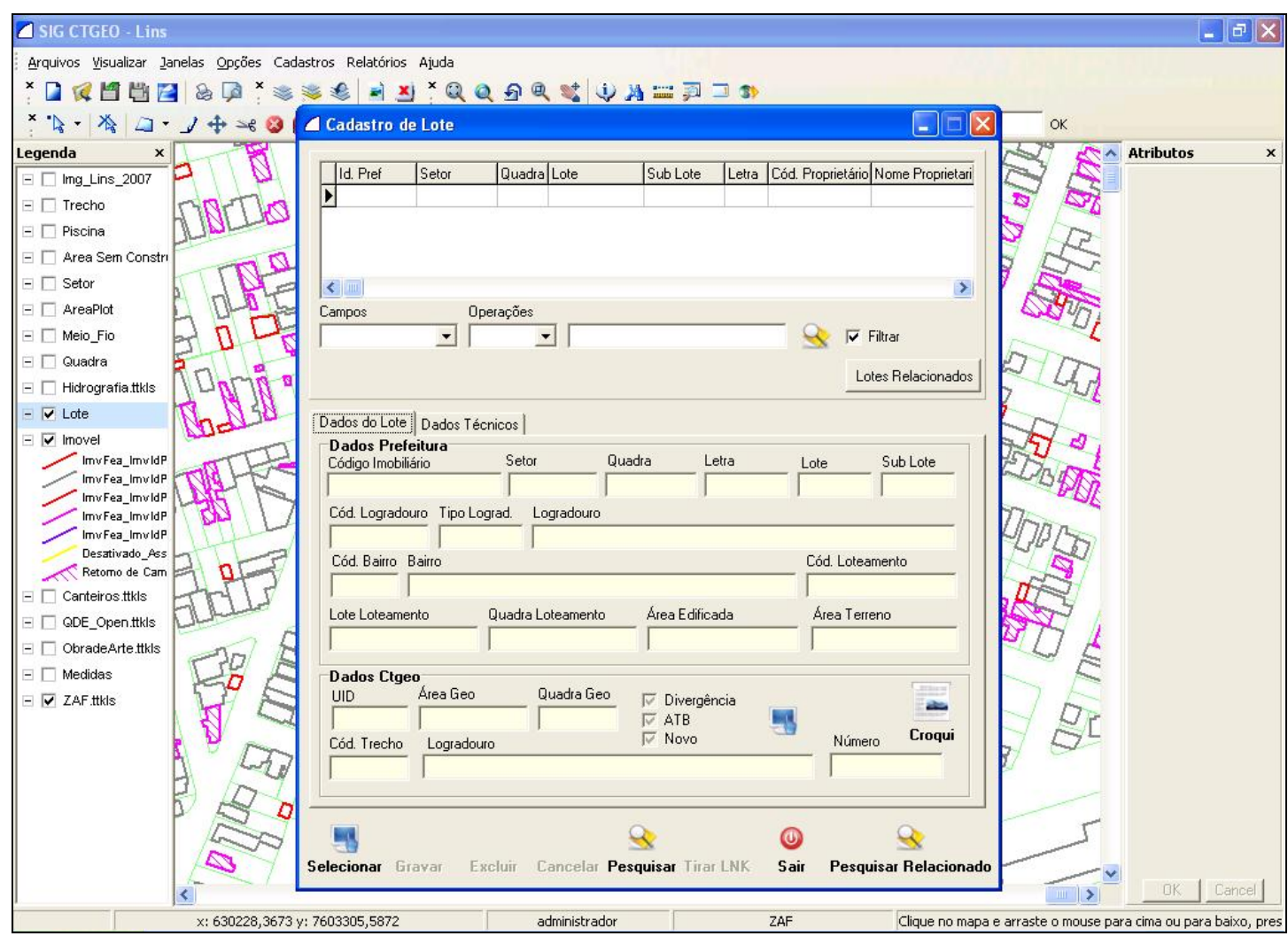

Figura 26 - Interface customizada da "tela de cadastro".

O software do sistema de informações geográficas implantado foi desenvolvido pela entidade responsável e possui formatos de arquivos proprietários, porém conversíveis para formatos usuais. 


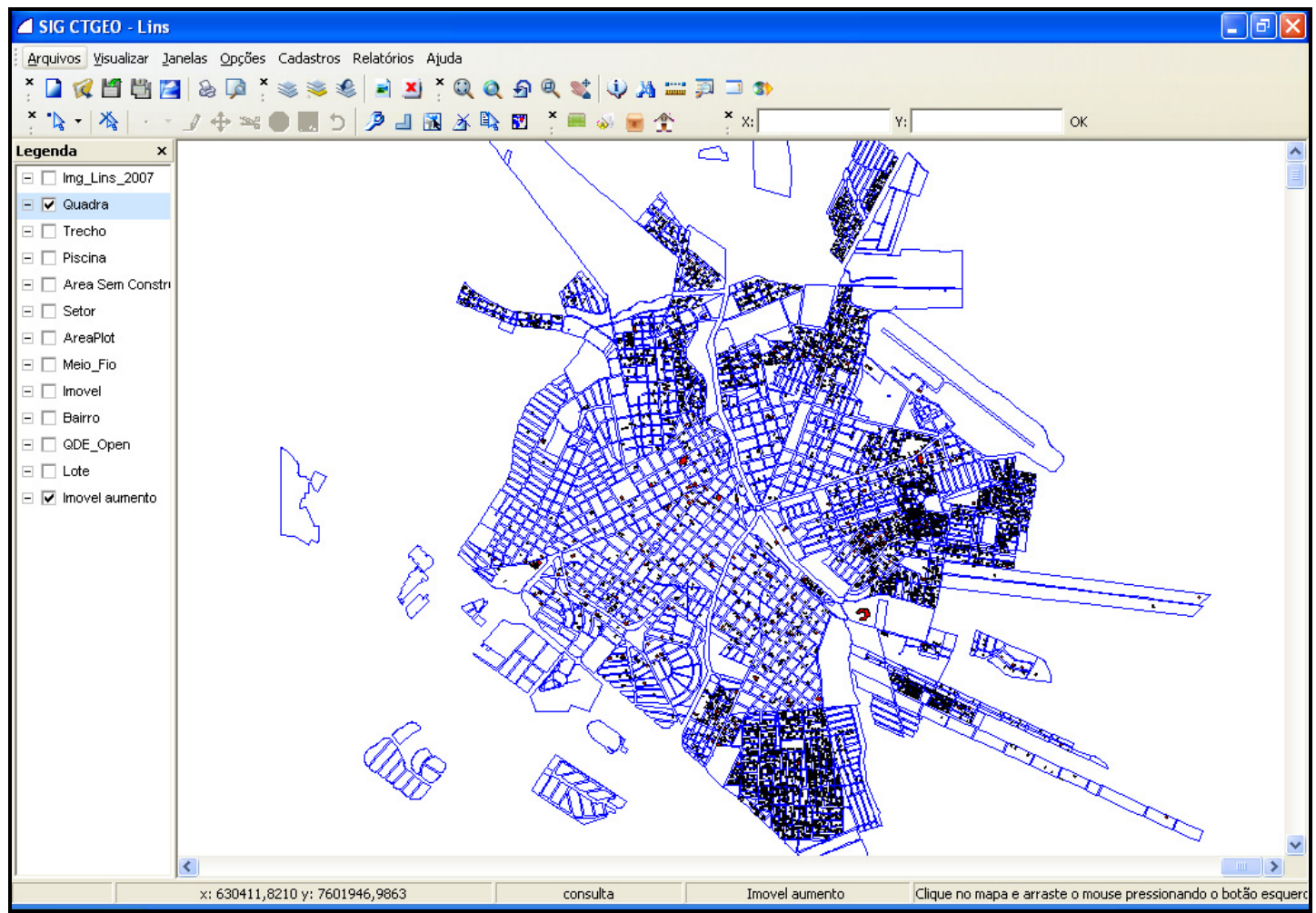

Figura 27 - Tela do software de sistema de informações geográficas desenvolvido pela entidade responsável no caso estudado.

Destaca-se que diferentes aplicações específicas podem utilizar o banco de dados geográficos, desde que adequadas aos modelos adotados para os dados geográficos e sua representação, para as entidades e para o banco de dados, nos diferentes níveis de abstração. Portanto, a compreensão dos modelos e dos requisitos que os determinam é fundamental para a utilização do potencial dos bancos de dados geográficos pela tecnologia em sistemas de informações geográficas. 


\section{Capítulo 3 - Utilização de Banco de Dados Geográfico}

\section{Simulação de Cálculo de Valor de Outorga Onerosa do Direito de Construir}

O presente capítulo apresenta um exemplo de utilização do banco de dados geográfico por meio de sua aplicação, em software de sistema de informações geográficas, para finalidade não prevista quando da concepção do sistema. Conforme o capítulo anterior, tal potencial decorre da adoção dos modelos para o banco de dados geográfico. Nesse sentido, o presente capítulo apresenta a simulação, por meio da utilização do banco de dados geográfico e de sistema de informações geográficas, do cálculo de valor de contrapartida financeira devida, para determinados imóveis, para obtenção de Outorga Onerosa do Direito de Construir, para o caso em estudo. Portanto, o presente capítulo visa exemplificar o potencial de utilização do banco de dados geográfico para aplicações diversas das previstas e sua dependência das definições dos modelos adotados para a constituição do banco de dados geográficos, por meio da descrição dos procedimentos e operações necessários para simulação do cálculo do valor de Outorga Onerosa do Direito de Construir. Para tanto, será utilizado o banco de dados geográfico do caso em estudo, fornecido pela 
entidade responsável pela implementação do sistema, e o software ArcGIS, da empresa ESRI, fornecido pela Universidade de São Paulo. Os procedimentos apresentados no presente capítulo tem como objetivo demonstrar a viabilidade de cálculo do $\operatorname{Voodc}$ por meio do método descrito e não levam em conta outros fatores para sua efetiva sistematização, em administração municipal.

A Outorga Onerosa do Direito de Construir no município foi criada pelo Plano Diretor ${ }^{22}$ e regulamentada pela Lei de Uso e Ocupação do Solo Urbano $^{23}$ e é um instrumento da política urbana municipal. A Outorga Onerosa do Direito de Construir constitui contrapartida financeira devida para construções que excedem o limite básico de construção, definido em lei. A Lei de Uso e Ocupação do Solo, no caso em estudo, determina um Coeficiente de Aproveitamento Básico $(C A B)$ único para toda a área urbana e equivalente a 1,0 (um), sendo o coeficiente de aproveitamento é obtido pela relação entre área construída e área do terreno.

$$
\mathbf{C A}=\mathbf{A C} / \mathbf{A T}
$$

Sendo:

$\mathrm{CA}=$ Coeficiente de Aproveitamento

$\mathrm{AC}=$ Área Construída $\left[\mathrm{m}^{2}\right]$

$\mathrm{AT}=$ Área do Terreno $\left[\mathrm{m}^{2}\right]$

\footnotetext{
${ }^{22}$ LINS, Lei Complementar n ${ }^{\circ} .950$, de 05 de outubro de 2006. Institui o Plano Diretor do Município de Lins. Diário Oficial do Município.

${ }^{23}$ LINS, Lei Complementar n ${ }^{\circ}$. 1.085, de 15 de agosto de 2008. Dispõe sobre o uso e ocupação do solo urbano de Lins. Diário Oficial do Município.
} 
A lei determina também uma alíquota de 0,25 e que o valor da outorga deve ser calculado em Unidades Fiscais Municipais (UFM), por meio da seguinte fórmula:

\section{VUoodc $=$ VV x $0,25\left[\mathrm{UFM} / \mathrm{m}^{2}\right]$}

Sendo:

VUoodc $=$ Valor Unitário da Outorga Onerosa do Direito de Construir por $\mathrm{m}^{2}$ de área construída excedente ao potencial básico $\left[\mathrm{UFM} / \mathrm{m}^{2}\right]$

$\mathrm{VV}=$ Valor Venal do terreno $\left[\mathrm{UFM} / \mathrm{m}^{2}\right]$

O VUoodc resultante da fórmula estabelecida na Lei de Uso e Ocupação do Solo Urbano é o valor unitário a ser pago por metro quadrado de área construída que excede o potencial construtivo definido pelo $C A B$, ou, em outros termos, é o valor a ser pago por metro quadrado de solo criado. Foi definida uma alíquota de 0,25 . O Valor Venal do terreno $(V V)$, utilizado como base de cálculo, é o valor unitário que consta na Planta Genérica de Valores (PGV), concebida de modo a diferenciar os valores venais (de venda) dos terrenos através da delimitação de Zonas de Abrangência Fiscal (ZAFs) na área urbana.

O valor final da outorga, definido como Voodc, desde que excedido o limite básico de construção, pode ser calculado multiplicando o valor unitário da outorga pela diferença entre área construída final e área construída básica, ou seja: 


\section{Voodc $=$ VUoodc $x(A C F-A C B)$}

Ou seja:

Voodc $=$ VV x 0,25 x (ACF $-A C B)$

Sendo:

VUoodc $=$ Valor Unitário da Outorga Onerosa do Direito de Construir por $\mathrm{m}^{2}$ de área construída excedente ao potencial básico [UFM/m²]

$\mathrm{ACF}=$ Área Construída Final $\left[\mathrm{m}^{2}\right]$

$\mathrm{ACB}=$ Área Construída Básica $\left[\mathrm{m}^{2}\right]$

$\mathrm{VV}=$ Valor Venal do terreno $\left[\mathrm{UFM} / \mathrm{m}^{2}\right]$

Observa-se ainda, que o valor final da contrapartida financeira $($ Voodc $)$ pode ser calculado também através da seguinte fórmula, válida apenas quando o $C A F$ é maior ou igual ao $C A B$, já que no caso do $C A F$ ser menor que o $C A B$, não há cobrança:

Voodc $=($ CAF - CAB $) \times A T \times$ VV x 0,25 $[\mathrm{UFM}]$

Sendo:

Voodc $=$ Valor da Outorga Onerosa do Direito de Construir $[$ UFM $]$

$\mathrm{CAF}=$ Coeficiente de Aproveitamento Final

$\mathrm{CAB}=$ Coeficiente de Aproveitamento Básico

$\mathrm{AT}=$ Área do Terreno $\left[\mathrm{m}^{2}\right]$

$\mathrm{VV}=$ Valor Venal da ZAF $\left[\mathrm{UFM} / \mathrm{m}^{2}\right]$ 
O $C A F$ é obtido pela razão entre a área construída final, ou seja, a área construída ser atualizada no cadastro imobiliário, e a área do terreno:

\section{$\mathrm{CAF}=\mathrm{ACF} / \mathrm{AT}$}

Sendo:

$\mathrm{CAF}=$ Coeficiente de Aproveitamento Final $\mathrm{ACF}=$ Área Construída Final $\left[\mathrm{m}^{2}\right]$

$\mathrm{AT}=$ Área do Terreno $\left[\mathrm{m}^{2}\right]$

O $C A B$ é determinado pela legislação pertinente e foi estabelecido o valor 1,0 . Assim, o $C A B$ determina a $A C B$ :

$\mathbf{C A B}=\mathbf{A C B} / \mathbf{A T}$

Se:

$\mathrm{CAB}=\mathbf{1 , 0}$

Então:

$\mathrm{ACB}=\mathrm{AT}$

Sendo:

$\mathrm{CAB}=$ Coeficiente de Aproveitamento Básico

$\mathrm{ACB}=$ Área Construída Básica

$\mathrm{AT}=$ Área do Terreno $\left[\mathrm{m}^{2}\right]$ 
Deve-se observar ainda que a legislação determina que a cobrança da outorga deve ser exigida apenas para as construções novas, ou seja, o potencial construtivo utilizado anteriormente a aprovação da lei não pode ser cobrado retroativamente. Dessa forma, os imóveis com Coeficiente de Aproveitamento $(C A)$ maior que 1,0 antes da aprovação da lei pagarão a outorga em caso de ampliações da área construída de então, enquanto que os imóveis com $C A$ inferior a 1,0 na data de aprovação da lei apenas deverão a outorga após a utilização do potencial construtivo básico. Assim, o cálculo do valor da outorga depende do coeficiente de aproveitamento quando da aprovação da Lei de Uso e Ocupação do Solo Urbano, sendo que os imóveis devem ser tipificados pela diferença de seu $C A$ em relação ao $C A B$ nesta data. Nesse sentido é necessário obter parâmetro que represente o direito adquirido sobre o solo criado anteriormente a aprovação da Lei de Uso e Ocupação do Solo. através da seguinte fórmula:

\section{CAda $=$ CAluosu $-\mathbf{1 , 0}$}

Sendo:

CAda $=$ Coeficiente de Aproveitamento do direito adquirido

CAluosu $=$ Coeficiente de Aproveitamento na data de aprovação da Lei de Uso e Ocupação do Solo Urbano

Assim, a fórmula a ser aplicada para o cálculo do Voodc depende do valor de $C A d a$ e da Área Construída Final $(A C F)$. 
Se $C A d a \geq 0$, então a fórmula para cálculo do $\operatorname{Voodc}$ é:

Voodc $=($ ACF - AC) $\times 0,25 \times$ VV $[$ UFM $]$

sendo:

Voodc $=$ Valor da Outorga Onerosa do Direito de Construir $[$ UFM $]$

$\mathrm{ACF}=$ Área Construída Final $\left[\mathrm{m}^{2}\right]$

$\mathrm{AC}=$ Área Construída aprovada e em vigor $\left[\mathrm{m}^{2}\right]$

$\mathrm{VV}=$ Valor Venal da ZAF $\left[\mathrm{UFM} / \mathrm{m}^{2}\right]$

Se CAscda $<0$, então as fórmulas para cálculo do Voodc podem ser:

Voodc $=($ ACF - ACB $) \times$ VV x 0,25 $[\mathrm{UFM}]$

Ou:

Voodc $=[(C A F-C A B) \times A T] \times$ VV x $0,25[\mathrm{UFM}]$

Sendo:

Voodc $=$ Valor da Outorga Onerosa do Direito de Construir $[$ UFM $]$

$\mathrm{CAF}=$ Coeficiente de Aproveitamento Final

$\mathrm{CAB}=$ Coeficiente de Aproveitamento Básico

$\mathrm{ACF}=$ Área Construída Final $\left[\mathrm{m}^{2}\right]$

$\mathrm{ACB}=$ Área Construída Básica

$\mathrm{AT}=$ Área do Terreno $\left[\mathrm{m}^{2}\right]$

$\mathrm{VV}=$ Valor Venal $\left[\mathrm{UFM} / \mathrm{m}^{2}\right]$ 
Dessa forma garante-se o direito adquirido sobre o coeficiente de aproveitamento resultante de construções cadastradas anteriormente à aprovação da lei e preserva-se o potencial construtivo remanescente dos imóveis que não atingiam o CAB na data de aprovação da lei. Nesse sentido, destaca-se a importância da previsão de atributo de data para as atualizações dos dados do cadastro, inclusive para possibilitar o conhecimento temporal das transformações da base de dados e inferir os fenômenos urbanos refletidos em tais transformações.

No presente estudo, por razões práticas, considerou-se a base de dados fornecida como refletindo os dados dos imóveis na data d aprovação da lei. Os arquivos foram fornecidos em extensão específica para o software desenvolvido e convertidos para sua utilização no software ArcGIS. Dessa forma, para cada entidade foram gerados arquivos .shp, .dbf e .shx.

O software ArcGIS possibilita diversas opções de visualização, inclusive por meio de consultas que combinam atributos das entidades. No caso em estudo, para favorecer a visualização da simulação do cálculo do Voodc, a visualização das representações geográficas foi configurada para refletir o valor do coeficiente dos imóveis, hipoteticamente na data de aprovação da Lei de Uso e Ocupação do Solo. 


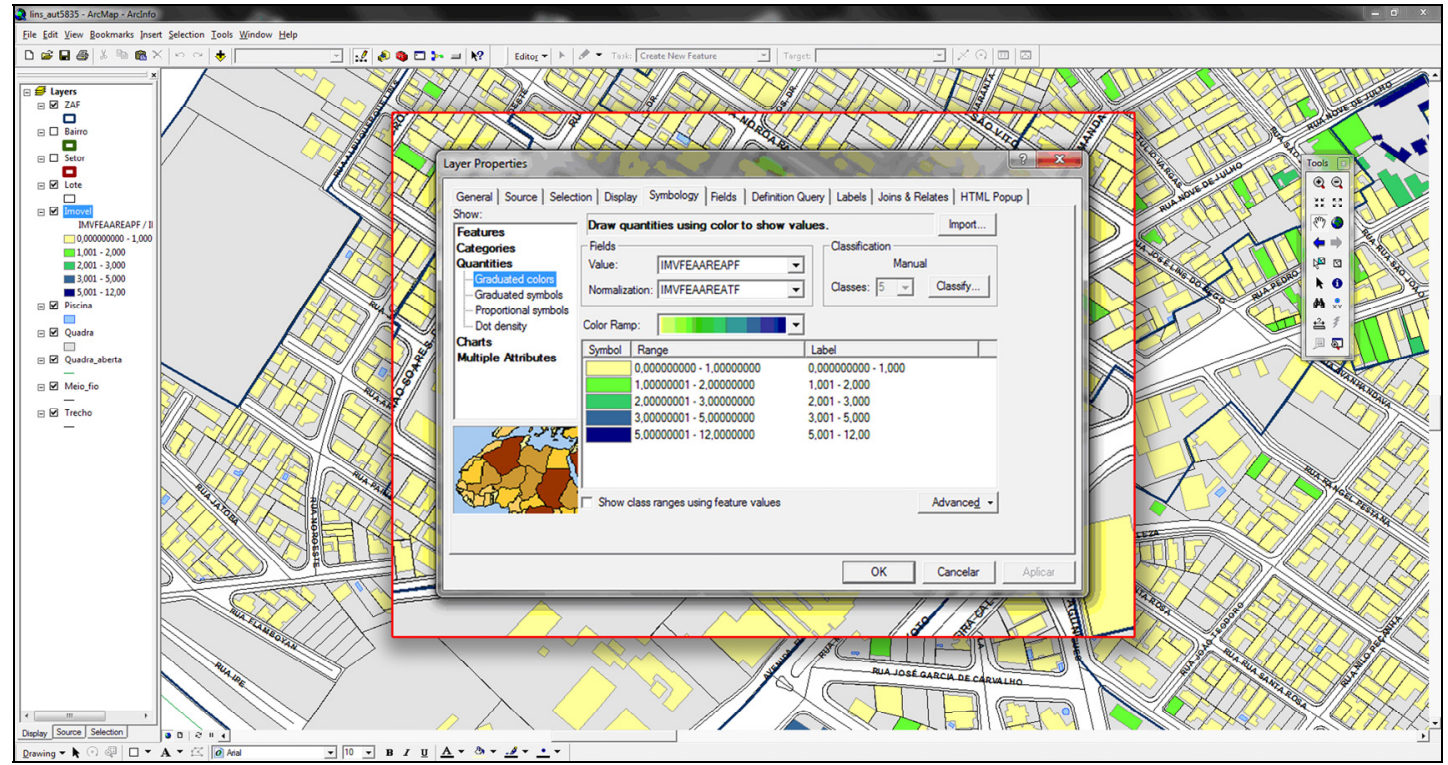

Figura 28 - Definição da apresentação visual da entidade "lote" pela relação entre os atributos: área construída (IMVFEAAREAPF) e área do terreno (IMVFEAAREATF). Graduação do resultado (Coeficiente de Aproveitamento) por cores (graduated colors). (Detalhe em destaque ampliado).

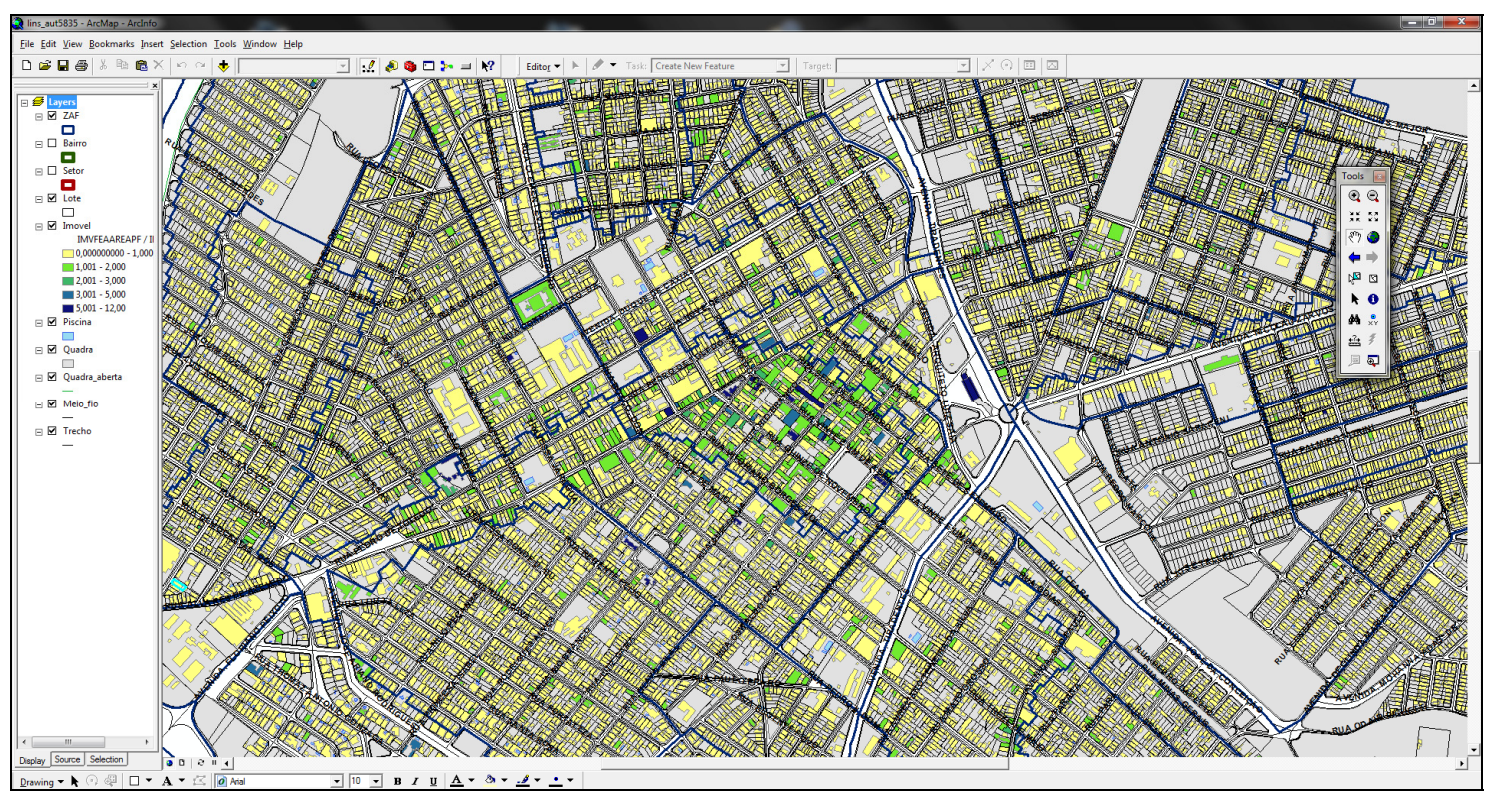

Figura 29 - Tratamento visual da entidade "lote", pela relação entre atributos de área construída e área do terreno, representando os valores de coeficiente de aproveitamento.

A opção pelo modelo de objeto geográfico, ou conjunto de geoobjetos, é fundamental para que os atributos das entidades possam ser individualizados e utilizados em diversas aplicações. Os objeto cadastrais, organizado pelo software ArcGIS em camadas ou layers, constituem conjuntos de 
geo-objetos, aos quais estão vinculados dados descritivos na forma de tabela, onde cada linha representa um registro e cada coluna um atributo, relacionável com qualquer outro dado geográfico presente no banco de dados geográfico. No caso estudado, os atributos necessários para o cálculo do valor da outorga onerosa do direito de construir de um determinado imóvel estão presentes nas entidades "Imóvel", "Lote" e "ZAF".

A entidade "Imóvel" possui atributos de área construída, características da construção, além do código do projeto arquitetônico aprovado pela Prefeitura.

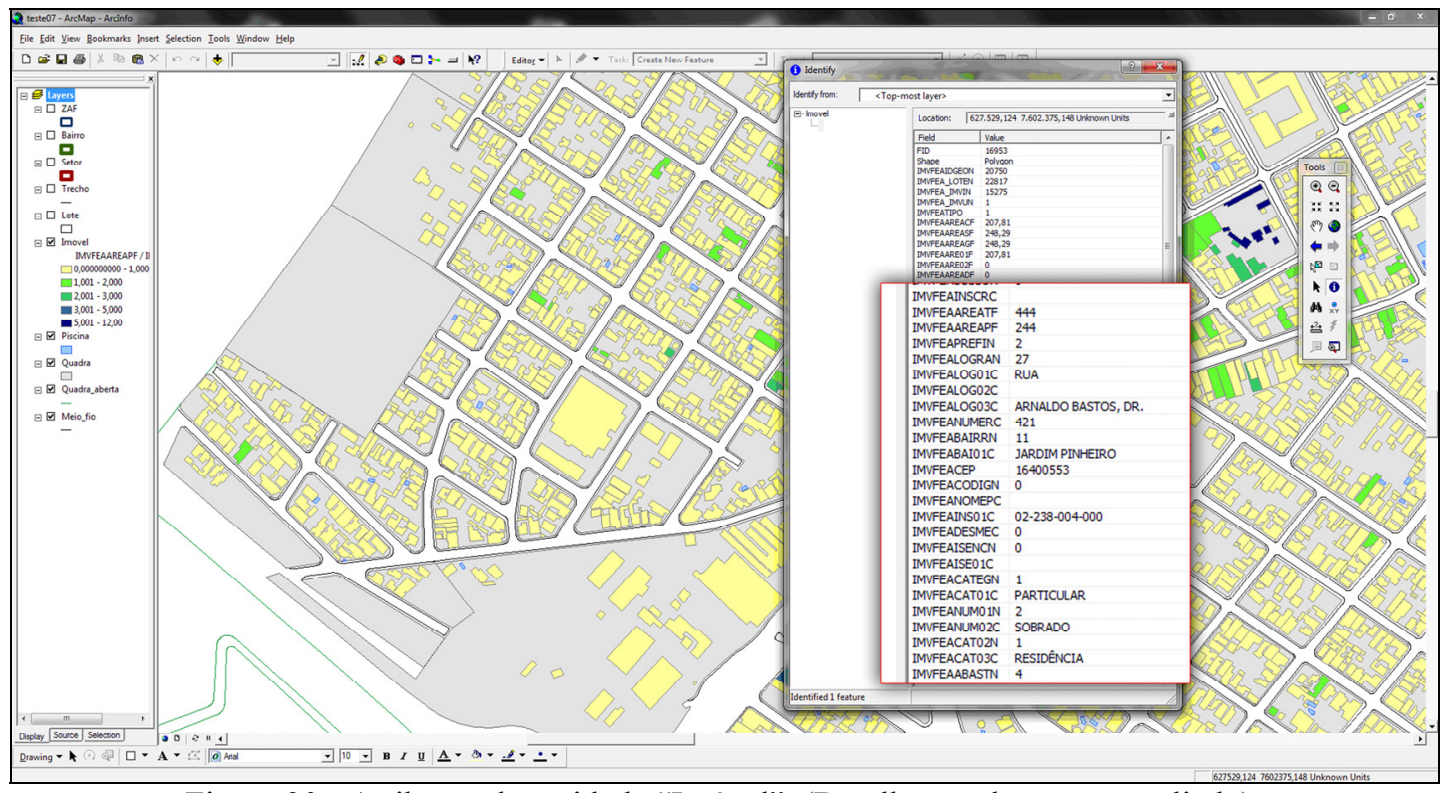

Figura 30 - Atributos da entidade "Imóvel". (Detalhe em destaque ampliado).

A entidade "ZAF" possui basicamente a atributos de valor venal da ZAF e código da ZAF. A entidade "Lote" possui atributos de área do terreno, endereço, código do lote, contribuinte, entre outros. 


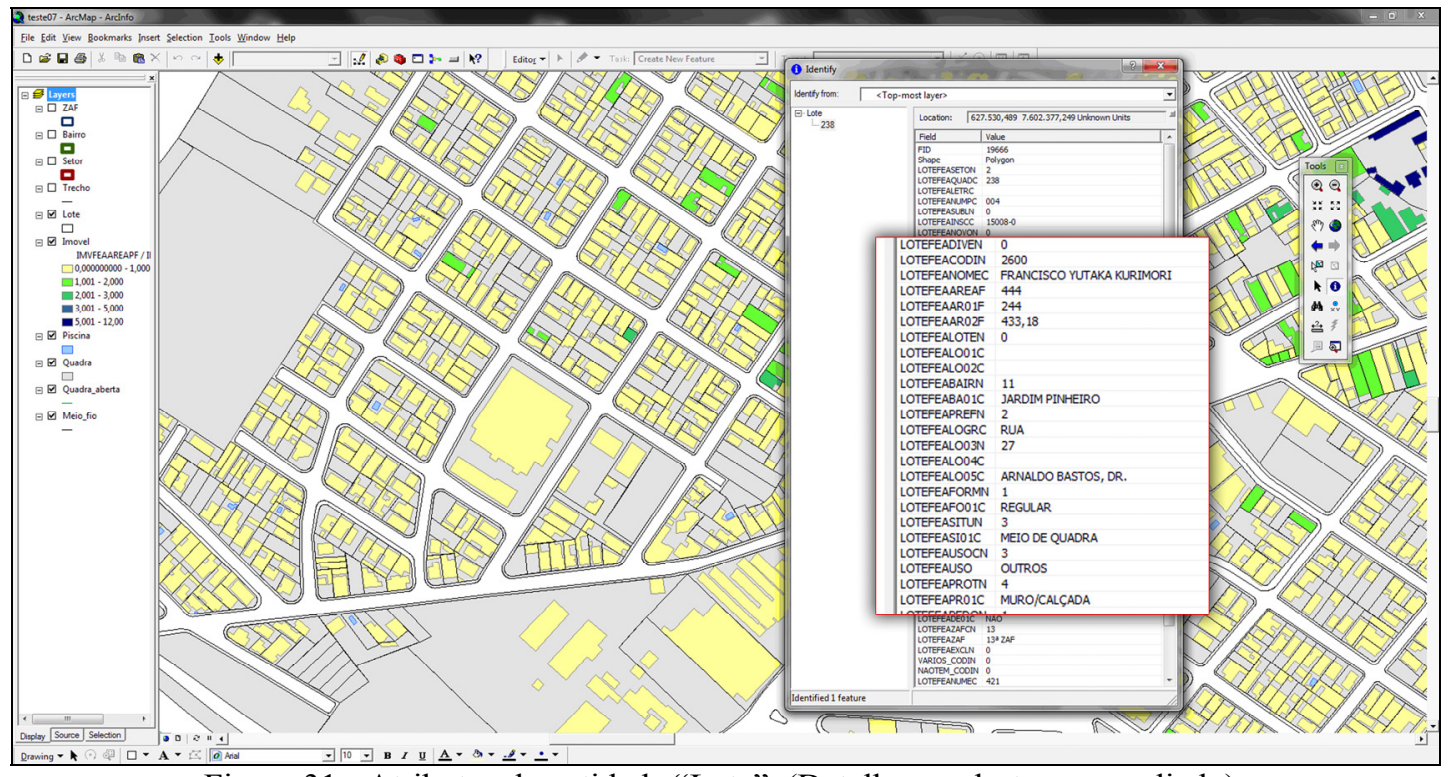

Figura 31 - Atributos da entidade "Lote". (Detalhe em destaque ampliado).

$\mathrm{Na}$ presente simulação, o Voodc é definido como atributo da entidade "Lote", assim como todos os atributos criados ou transpostos de outras entidades, para compor o cálculo da outorga.

Para o cálculo do $C A d a$, é necessário primeiramente calcular o $C A$ da entidade imóvel, por meio da operação Field Calculator, em seguida adicionar tais atributos à entidade "Lote" transpostos da entidade "Imóvel" através da operação Join. Outra alternativa é transpor os atributos de área construída e área de terreno da entidade "imóvel" para a entidade "lote" e então realizar os cálculos. 


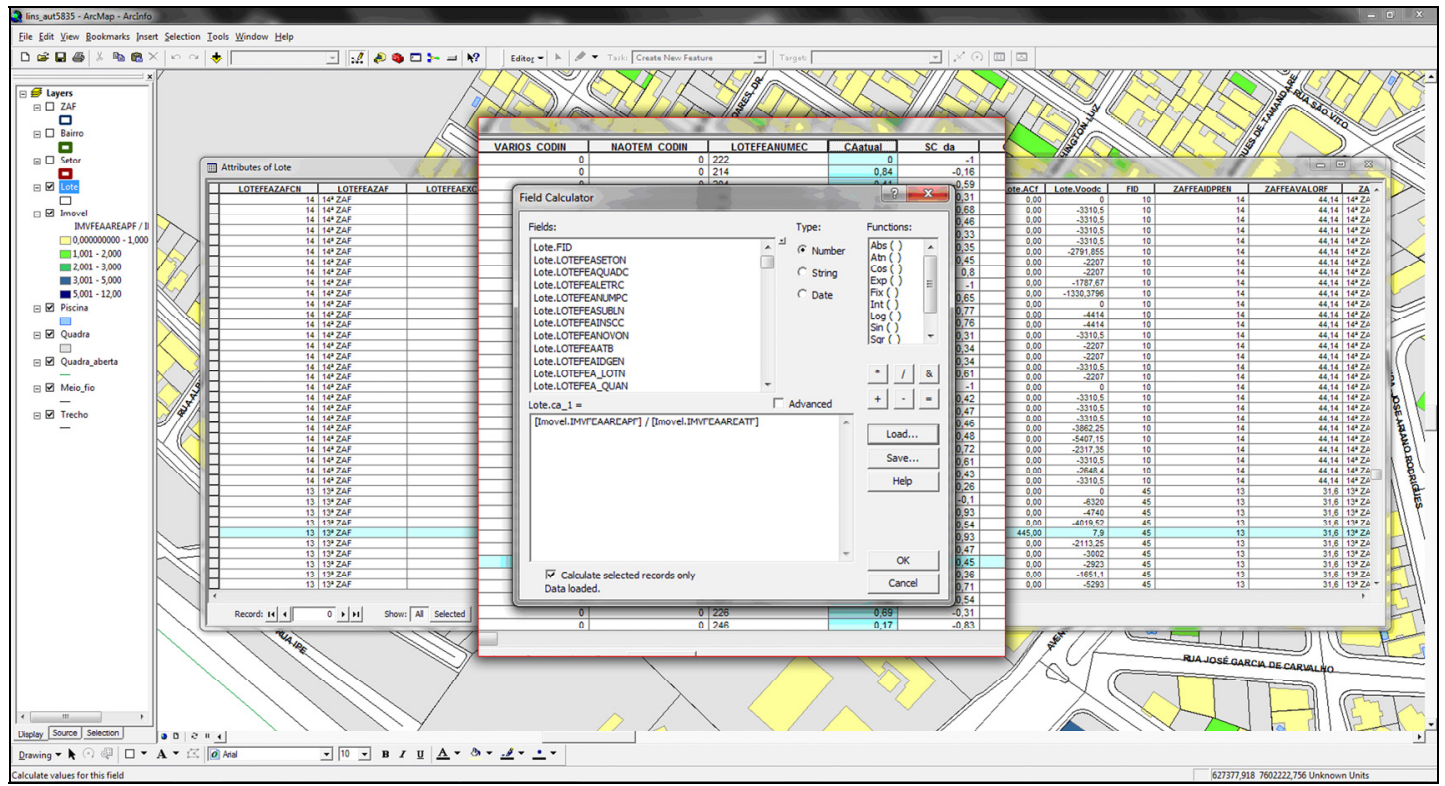

Figura 32 - Cálculo do $C A$. (Detalhe em destaque ampliado).

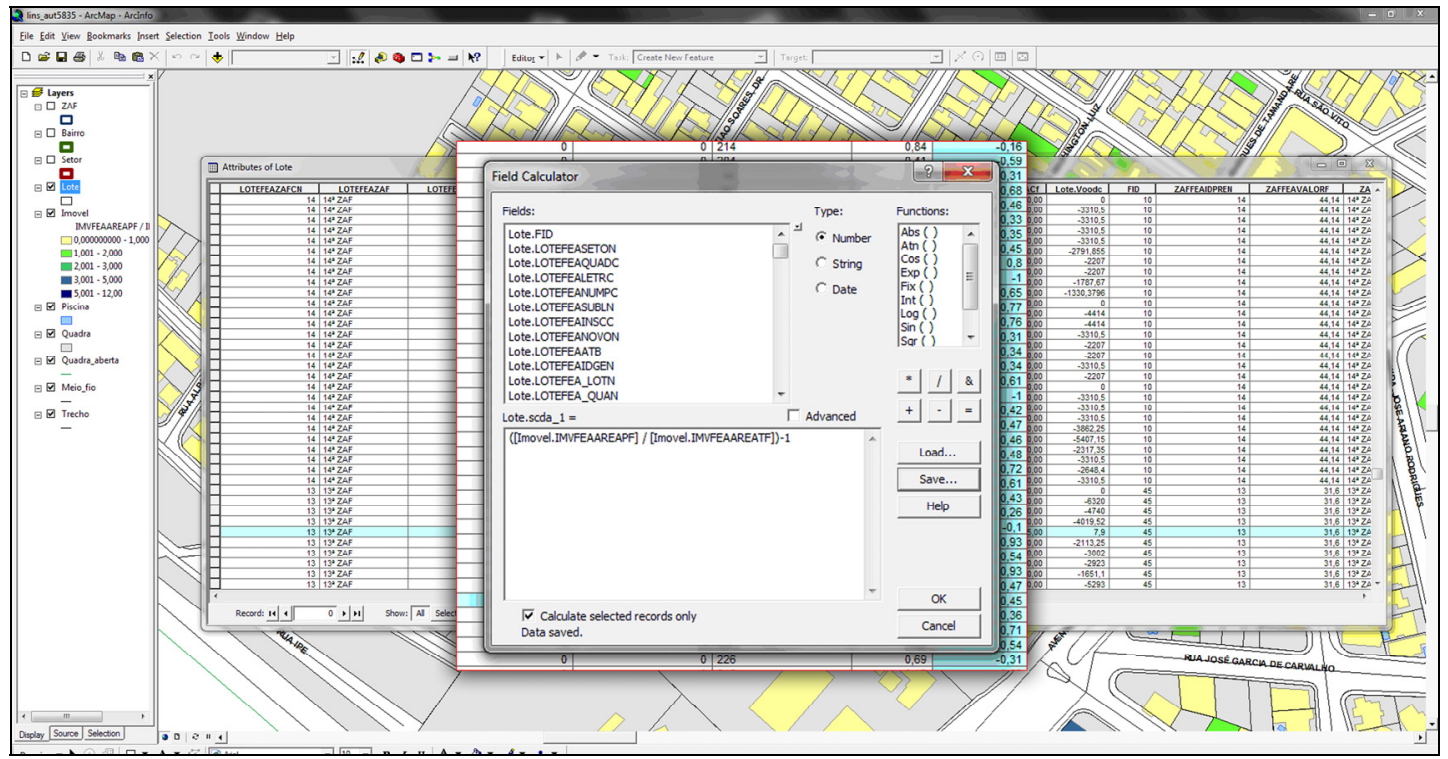

Figura 33 - Cálculo do CAda. (Detalhe em destaque ampliado). 


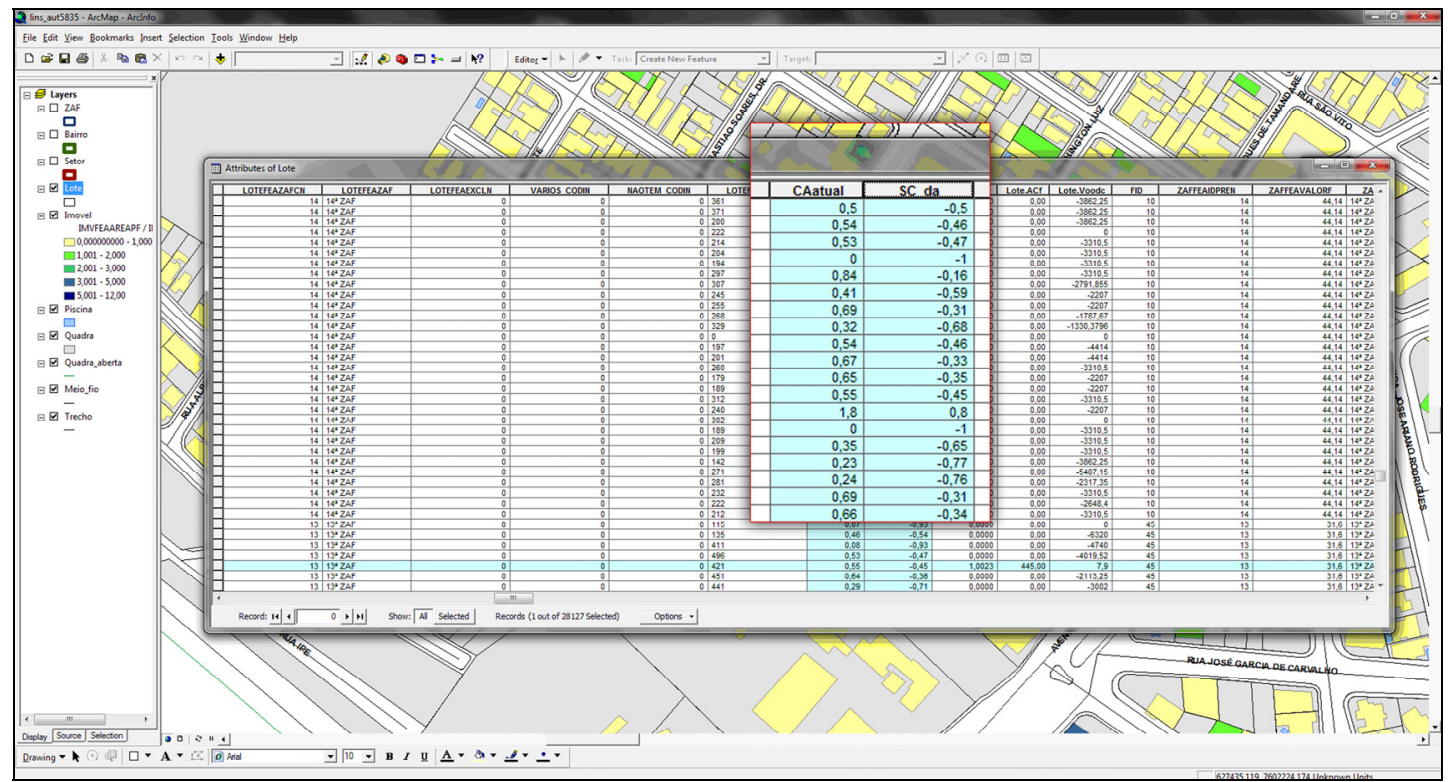

Figura 34 - Atributos adicionados à tabela de atributos da entidade "Lote": CA e CAda. (Detalhe em destaque ampliado).

Da mesma forma, atributos de valor venal da entidade "ZAF" também foram transpostos para a entidade "Lote" através de operação Join. Como o valor venal da ZAF da base de dados fornecida é o valor unitário, por metro quadrado, o valor venal unitário da outorga onerosa do direito de construir pode ser obtido diretamente na transposição dos valores da coluna multiplicados pela alíquota de 0,25 , já que o CAB é definido por lei com o valor 1,0 . 


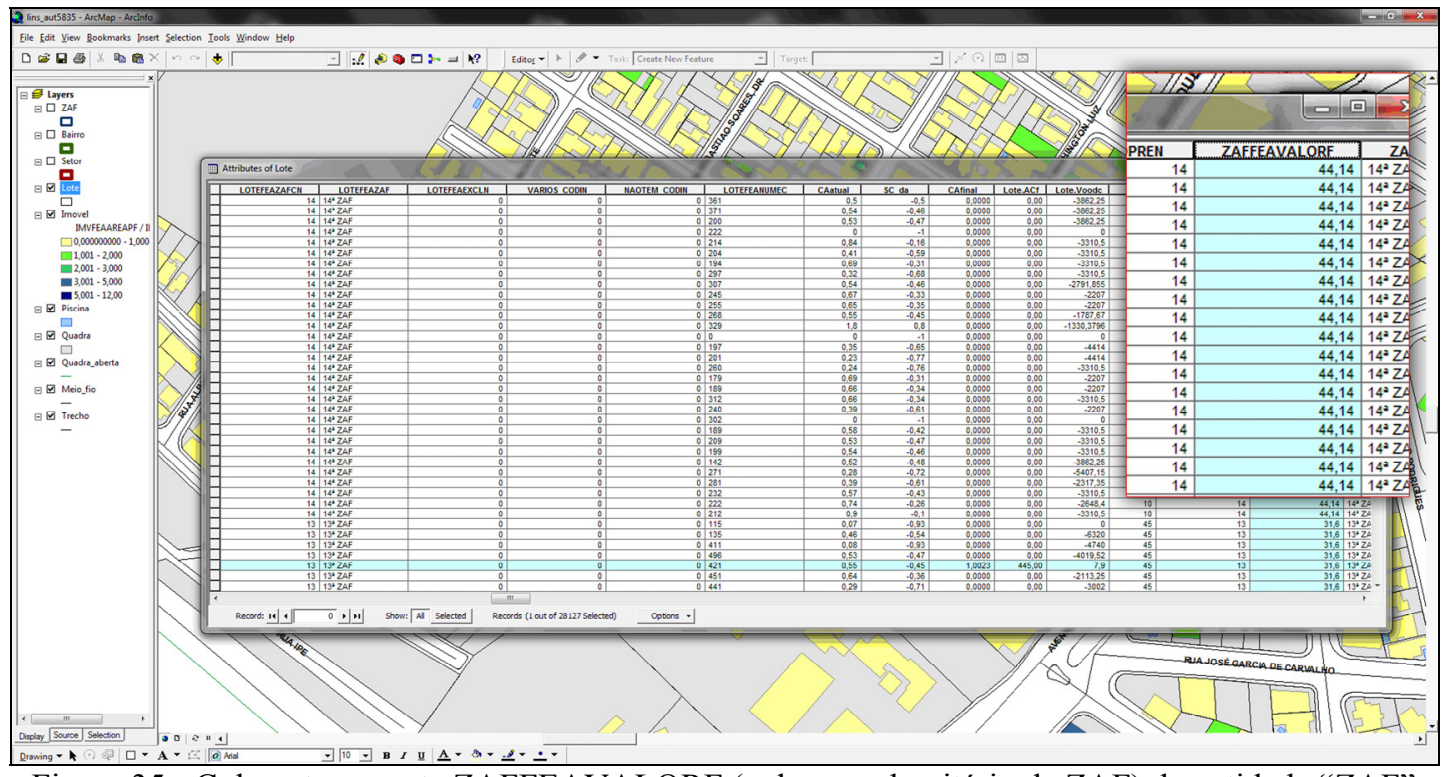

Figura 35 - Coluna transposta ZAFFEAVALORF (valor venal unitário da ZAF) da entidade "ZAF" para a entidade "Lote". (Detalhe em destaque ampliado).

Foram adicionadas à entidade "Lote" colunas de atributos de área construída final $(A C F)$ e coeficiente de aproveitamento final $(C A F)$.

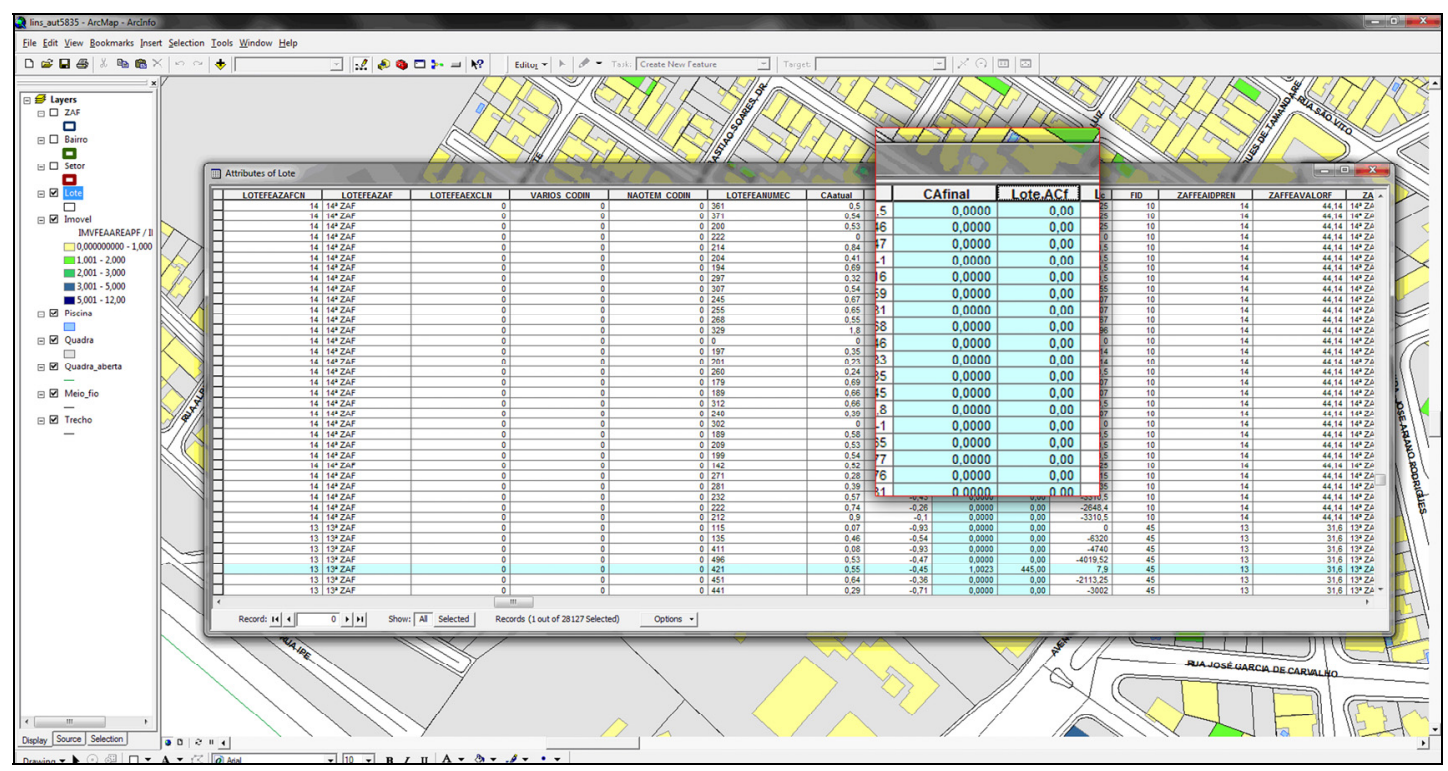

Figura 36 - Colunas de atributos adicionadas: área construída final $(A C F)$ e coeficiente de aproveitamento final $(C A F)$. (Detalhe em destaque ampliado).

A área construída final é a área apresentada em uma eventual solicitação por parte de interessado para aprovação de projeto arquitetônico de 
construção, ampliação ou demolição de edificação, ou em casos de regularização. No caso do sistema implantado em estudo, esse atributo é inserido em um novo registro, referente ao novo projeto aprovado para o imóvel, sendo imprescindível também a adição de atributo de data da aprovação e a capacidade de atualização do código do imóvel. Para o presente estudo, a $A C F$ foi concebida apenas como mais um atributo da entidade "Lote", simplesmente para viabilizar o cálculo do Voodc. O CAF, então, é calculado pela razão entre $A C F$ e $A T$.

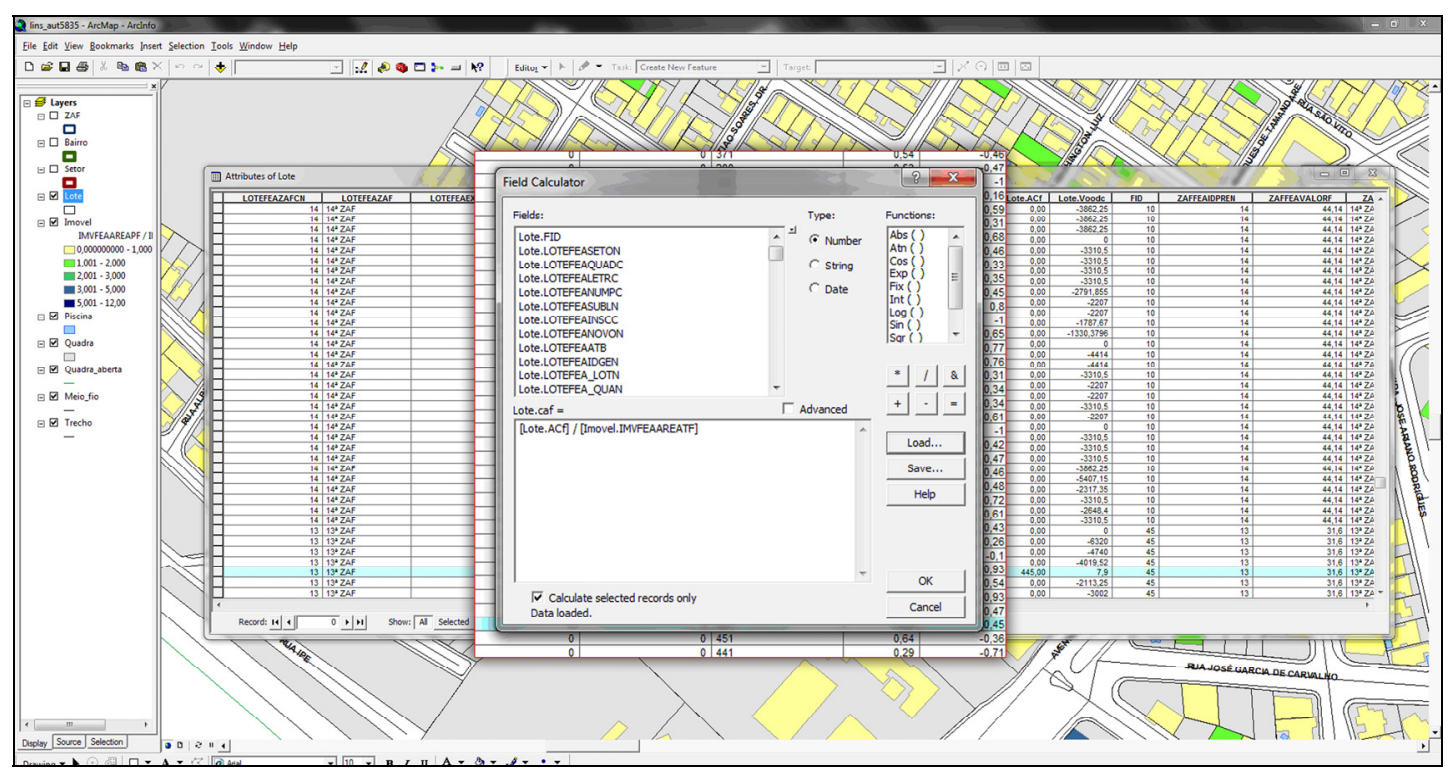

Figura 37 - Cálculo da $C A F$. (Detalhe em destaque ampliado).

O cálculo do Voodc exige a utilização de duas expressões, conforme apresentado anteriormente, para valores de CAda maiores ou iguais a zero e para valores de $C A d a$ menores que zero. 


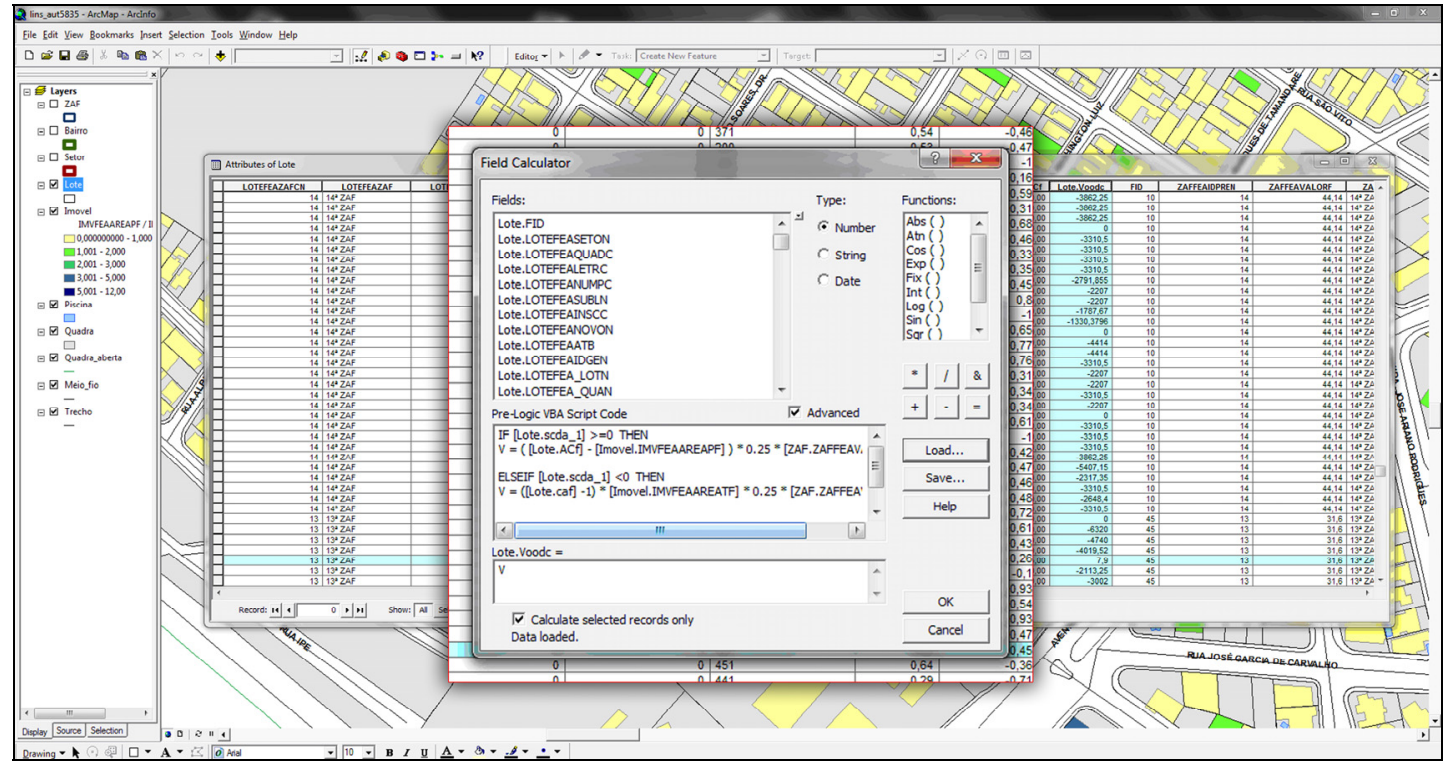

Figura 38 - Cálculo do Voodc com utilização de duas expressões, condicionadas ao valor do CAda.

(Detalhe em destaque ampliado).

Dessa forma, uma vez inserido um novo valor para área construída no campo $A C F$ (área construída final) e realizados os cálculos, obtemos o valor da Outorga Onerosa do Direito de Construir (Voodc), em UFM (Unidade Fiscal Municipal), a ser exigido como contrapartida financeira para aprovação ou regularização de projetos arquitetônicos de construções com área maior que o potencial construtivo básico.

Por fim, a simulação do cálculo no sistema de informações geográficas foi realizada em dois lotes diferenciados pelo valor de seu CAda, sendo um menor que zero e outro maior que zero.

O lote com CAda menor que zero possuía, hipoteticamente na data de aprovação da Lei de Uso e Ocupação do Solo, área construída cadastrada de 244 $\mathrm{m}^{2}$ e área de terreno de $444 \mathrm{~m}^{2}$, com $C A$ igual a 0,55 e $C A d a$ igual a $-0,45$. 


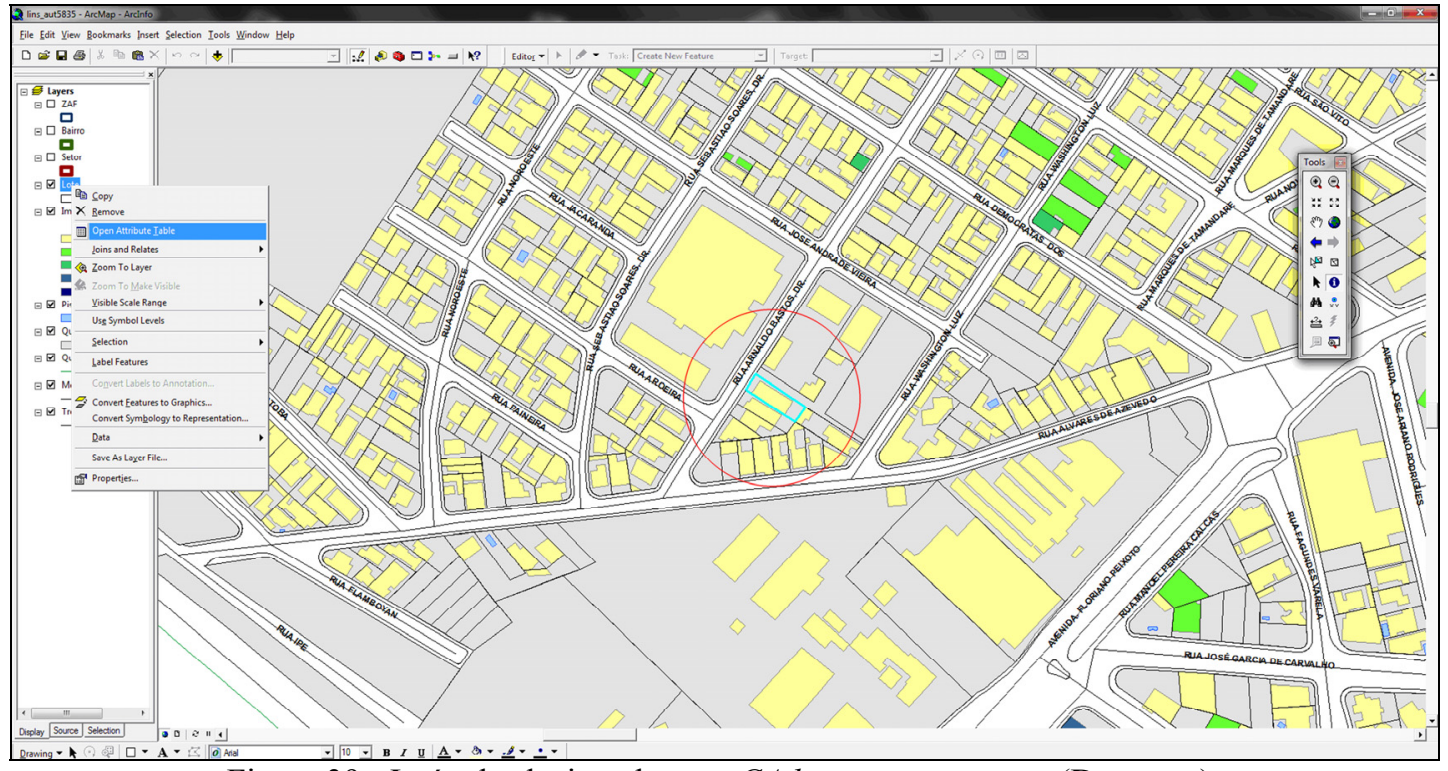

Figura 39 - Imóvel selecionado com CAda menor que zero. (Destaque).

Para a simulação do valor da outorga, foi inserido, por meio da função Start Editing, um valor de área construída de $445 \mathrm{~m}^{2}$, ou seja, $1 \mathrm{~m}^{2}$ construído acima do potencial construtivo básico, porém representando um acréscimo de 201,00 $\mathrm{m}^{2}$ em relação à área construída anterior.

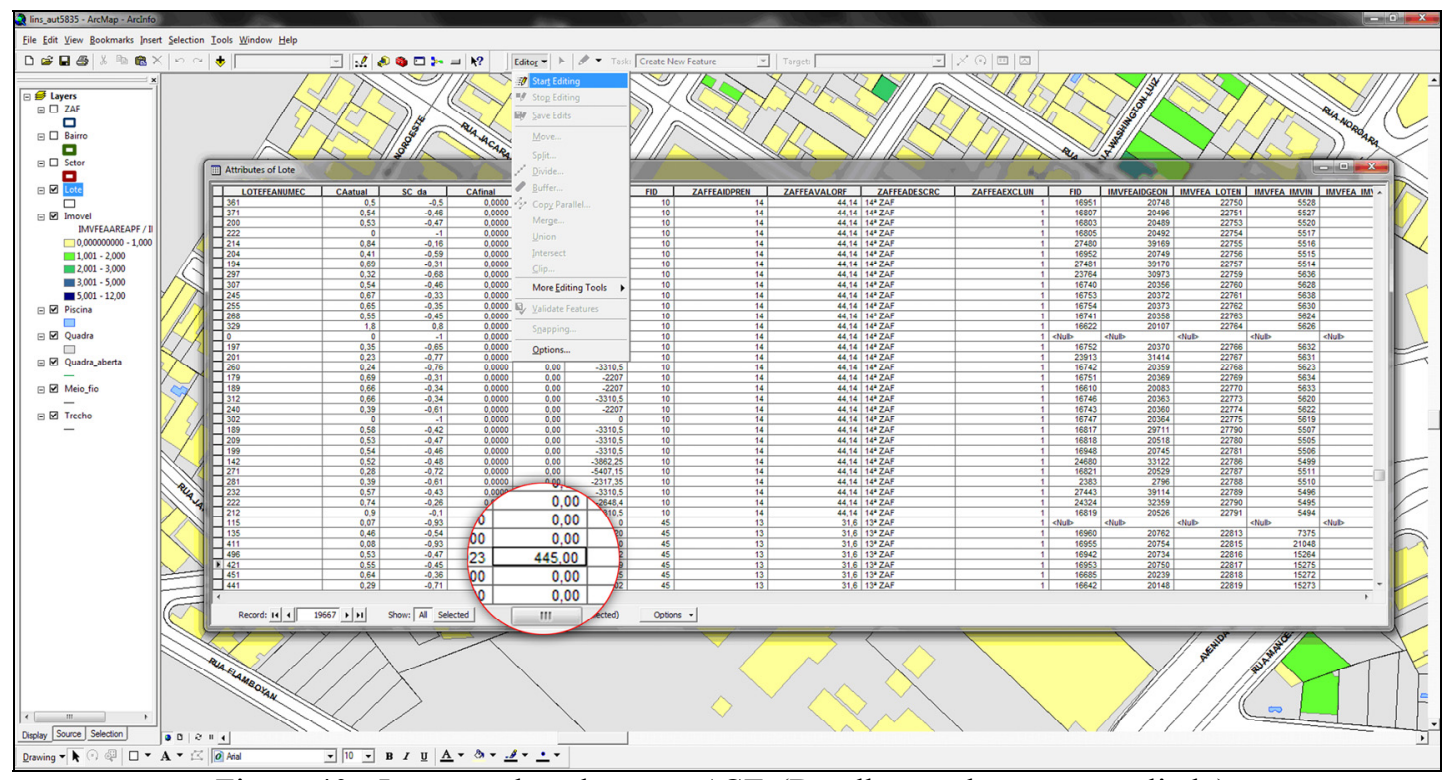

Figura 40 - Inserção de valor para $A C F$. (Detalhe em destaque ampliado). 


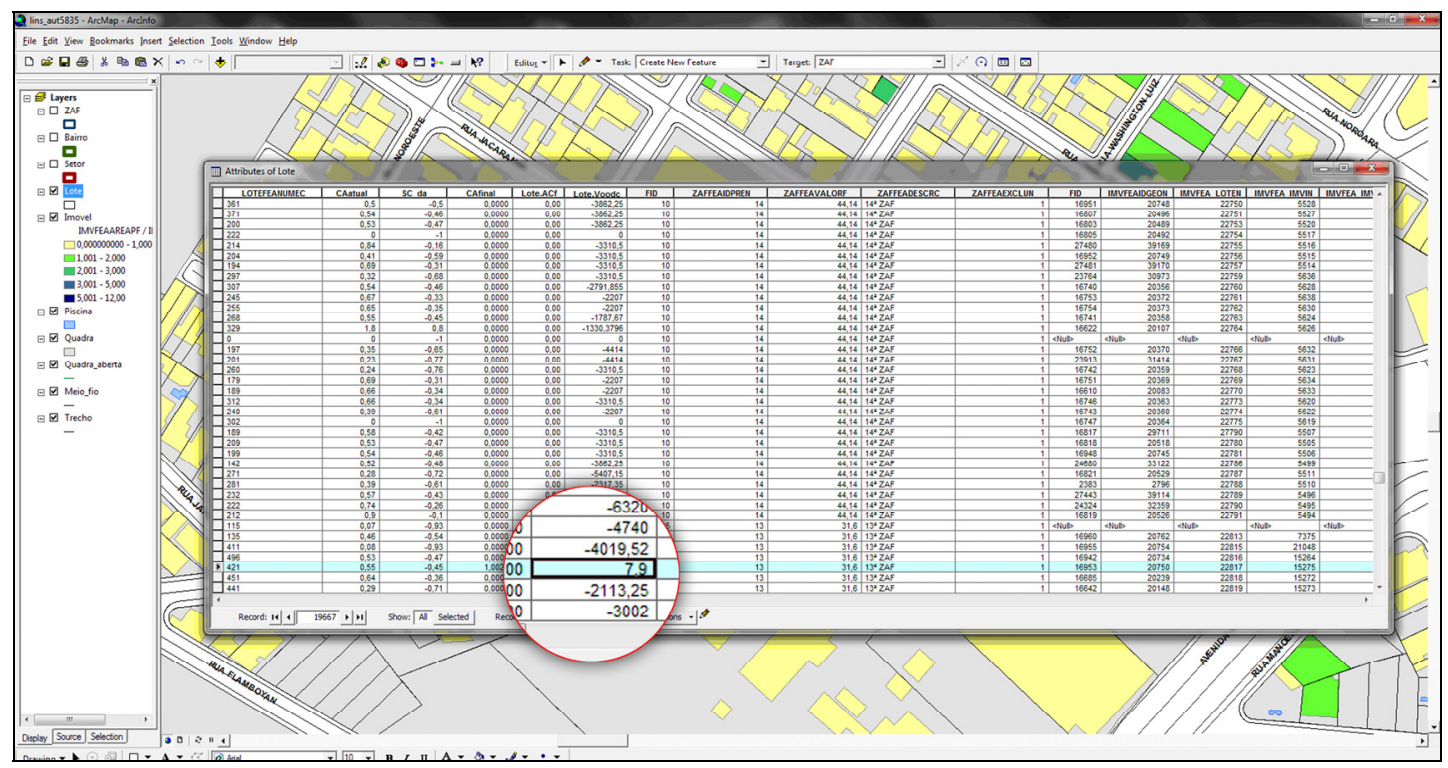

Figura 41 - Voodc (Valor da Outorga Onerosa do Direito de Construir) obtido na simulação. (Detalhe em destaque ampliado).

O cálculo do Voodc simulado pelo sistema apresentou resultado de valor que está de acordo com as determinações da Lei de Uso e Ocupação do Solo Urbano.

Para o segundo tipo de imóvel, com CAda maior que zero, foi selecionado um lote com área de terreno $(A T)$ de $170 \mathrm{~m}^{2}$ e área construída $(A C)$ de 345,24 $\mathrm{m}^{2}$, também hipoteticamente considerados na data de aprovação da Lei de Uso e Ocupação do Solo, com $C A$ igual a 2,03 e $C A d a$ igual a 1,03. 


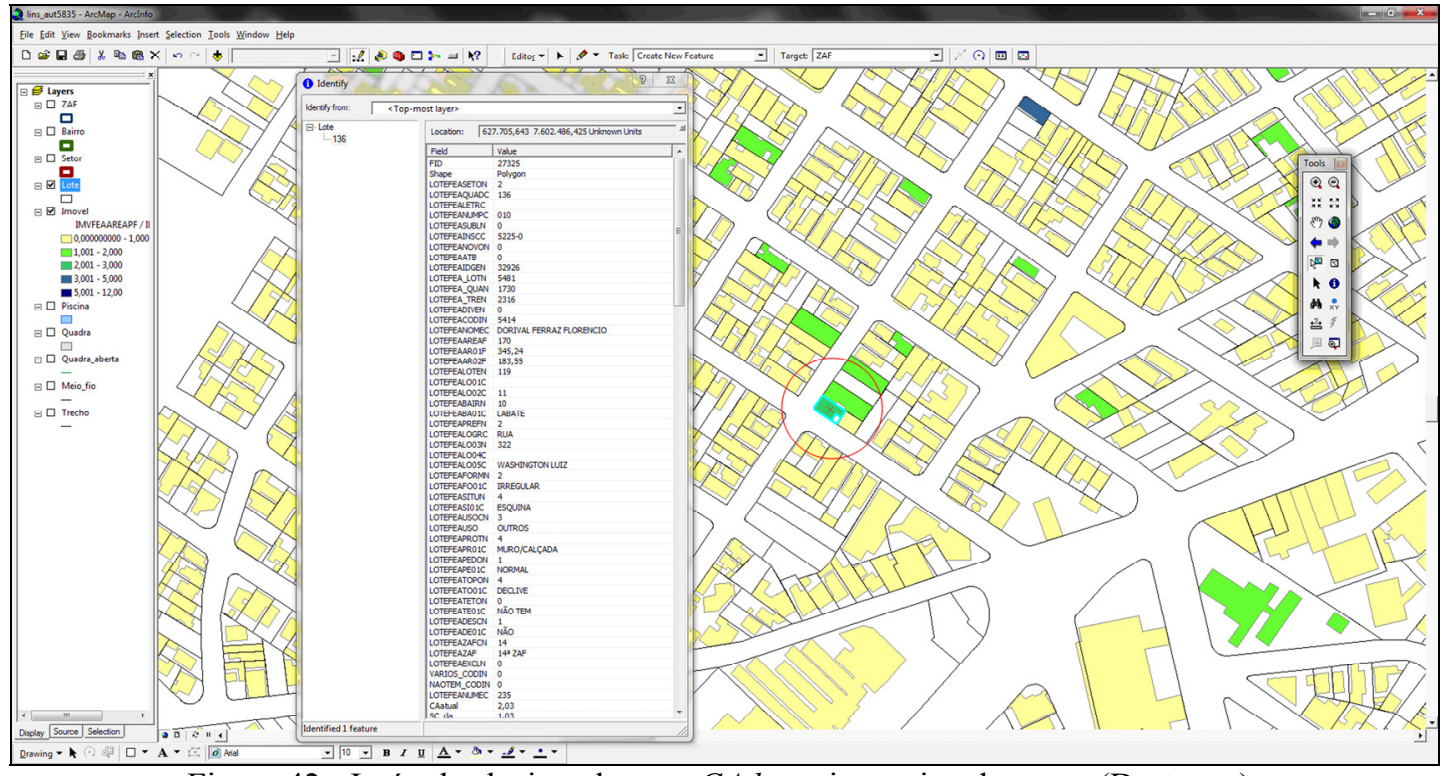

Figura 42 - Imóvel selecionado com CAda maior ou igual a zero. (Destaque).

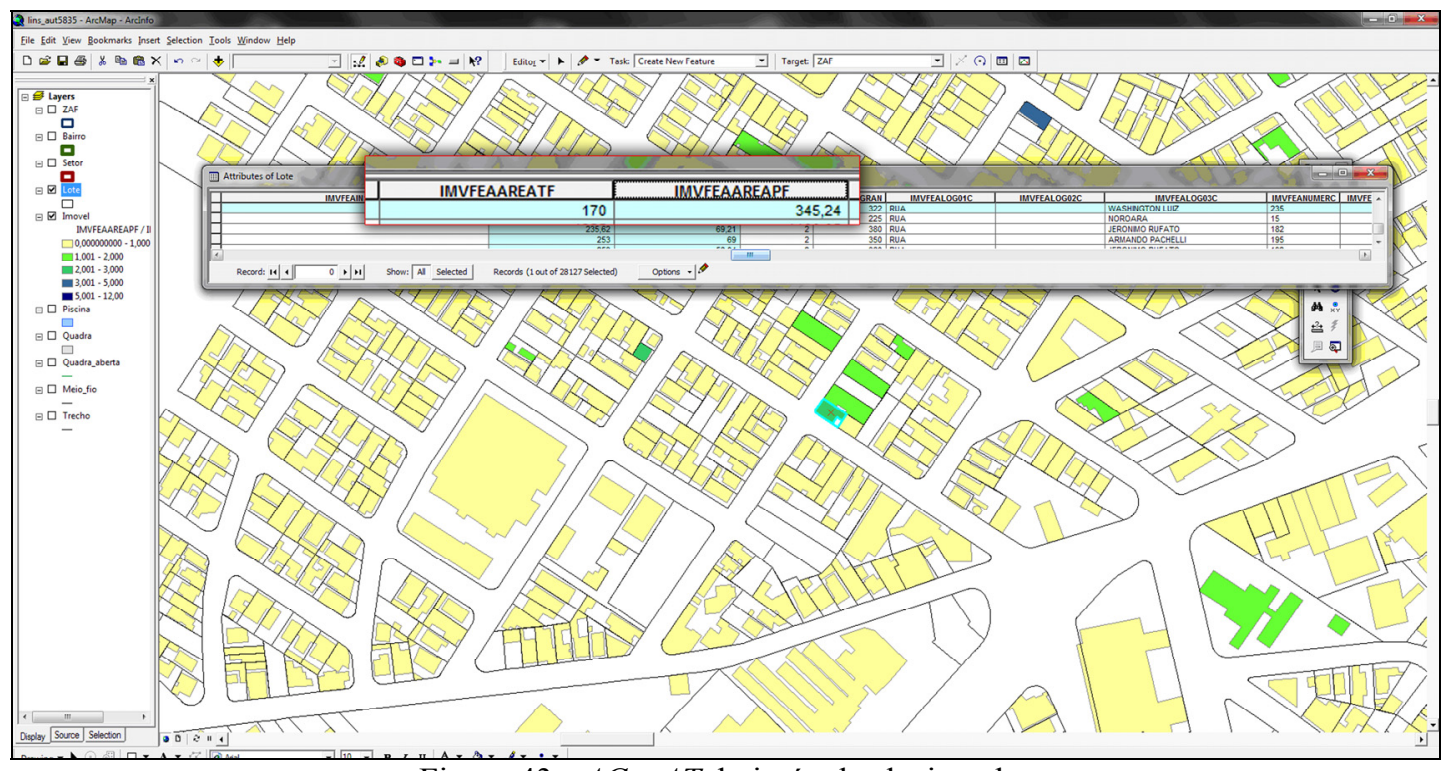

Figura $43-A C$ e $A T$ do imóvel selecionado.

Diferente do primeiro tipo de imóvel, para a simulação do valor da outorga, foi inserido um valor de área construída final de $1 \mathrm{~m}^{2}$ construído acima da área construída anteriormente cadastrada, ou seja, de 346,24 m².

O cálculo do Voodc feito pelo sistema apresentou resultado de valor que também está de acordo com as determinações da Lei de Uso e Ocupação 
do Solo Urbano do município e leva em consideração o direito adquirido sobre o coeficiente de aproveitamento do imóvel anterior à aprovação da lei.

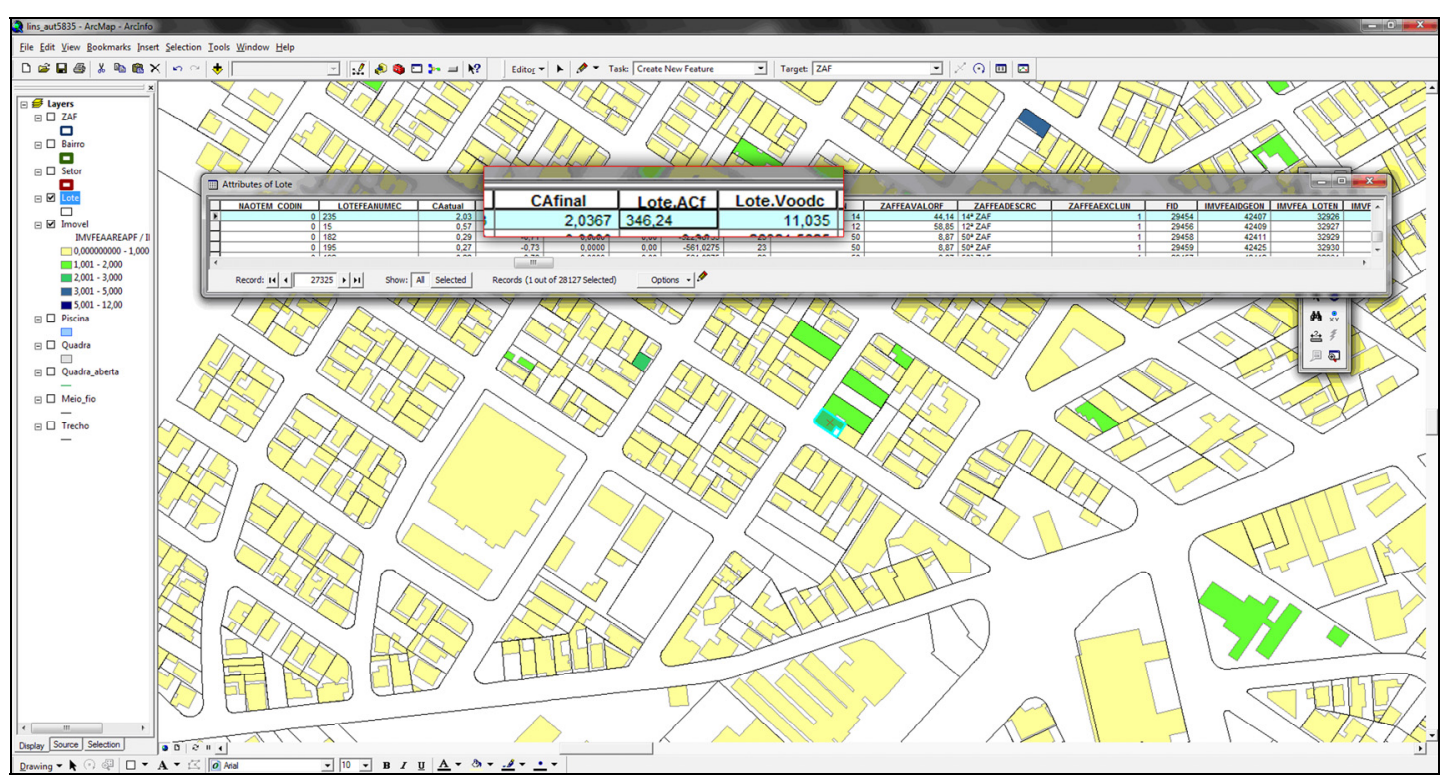

Figura 44 - Cálculo do Voodc (Valor da Outorga Onerosa do Direito de Construir).

Assim, o cálculo do Valor da Outorga Onerosa do Direito de Construir por meio da utilização do banco de dados geográfico e de sistema de informações geográfico se mostrou viável oferecendo precisão e segurança. 


\section{Capítulo 4 - Conclusão}

O potencial de utilização de bancos de dados geográficos por sistemas de informações geográficas depende dos requisitos definidos em sua concepção e dos modelos adotados para o atendimento de tais requisitos.

Em sistemas de banco de dados geográficos para identificação de áreas construídas e cadastramento imobiliário, a utilização de dados de sensoriamento remoto, em especial imagens de satélite e aerofotogrametria, pode proporcionar a racionalização dos custos de vistorias e levantamentos de campo, podendo ser, nesse sentido, considerado requisito importante para a viabilização da implementação do sistema. Para tanto, é imprescindível que tais imagens possuam parâmetros adequados ao método adotado, em especial no que diz respeito às resoluções espacial, espectral, radiométrica e temporal. Outro requisito importante para a utilização de imagens com tais propósitos é a realização de procedimento de ortorretificação, de modo a aproximá-la de uma projeção ortogonal da superfície do terreno, reduzindo as distorções e possibilitando maior precisão na obtenção de áreas. 
O georreferenciamento da imagem, relacionado ao conceito de região geográfica, não constitui requisito essencial do ponto de vista da obtenção de áreas, mas é requisito desejável na medida em que possibilita sua utilização, enquanto base cartográfica, para apoiar diversas atividades comuns às administrações municipais, em especial as relacionadas à gestão e ao planejamento urbano, onde o posicionamento em sistemas de referência ou de projeção é necessário, tais como localização por coordenadas, levantamentos topográficos, registro de parcelamentos ou imóveis, entre outros.

Com relação aos modelos de dados geográficos, considerando os objetivos do banco de dados geográfico e a própria natureza dos dados, observa-se que, não obstante a utilização de dados de sensoriamento remoto, de representação matricial, o modelo cadastral de dados geográficos, com representação vetorial, atende mais eficientemente aos requisitos comumente observados em cadastros imobiliários, como a necessidade de abranger diversas informações descritivas vinculadas às feições espaciais, sendo as mesmas passíveis de atualizações e modificações, inclusive no que diz respeito ao seu relacionamento e a organização e delimitação clara dos objetos representados.

Da mesma forma, a adoção de modelo de geo-objeto para entidades, possibilitando a organização de conjuntos de objetos em classes, constituindo, mais especificamente, objeto cadastral, ou conjunto de geo-objetos, atende aos requisitos de vínculo com atributos não espaciais, independência lógica 
dos dados, delimitação espacial clara e associação a múltiplas localizações geográficas.

Enquanto ferramenta de apoio da administração pública municipal o sistema implantado deve resultar em maior eficiência no atendimento aos processos ligados ao setor de cadastro imobiliário, especialmente em atividades que exigem consultas ao banco de dados e emissão de determinados documentos, permitindo a consulta precisa de qualquer tipo de informação oriunda do banco de dados do cadastro imobiliário. Nesse sentido, o modelo relacional atende com maior eficiência aos requisitos exigidos para o banco de dados geográfico e o sistema de informações geográficas para o caso estudado, pois contém as características de um de banco de dados convencional (não geográfico), como armazenamento, manipulação, análise, recuperação e seleção de dados, mas permite integrar o componente geográfico, ou espacial.

Os modelos adotados para o banco de dados geográficos enfocado no presente estudo possibilitam também a realização de análises espaciais e simulações de situações hipotéticas, fornecendo subsídios em processos decisórios. Além disso, o banco de dados geográficos concebido a partir de tais modelos permite explorar as relações topológicas da geometria dos objetos das entidades, de forma independente, possibilitando maior capacidade de atualização da estrutura do banco de dados, se adequando com maior eficiência às demandas oriundas da dinâmica urbana. Outra característica relevante é a capacidade do banco de dados armazenar dados ou informações não oficiais, de caráter mais subjetivo, como observações 
descritivas, sendo possível também se vincular a outros bancos de dados, podendo constituir assim um cadastro multifinalitário.

Um requisito importante, do ponto de vista da implementação do sistema, uma vez que a base de dados contém grande volume de registros, refere-se ao procedimento de geocodificação, que deve ser realizável de forma confiável, segura e eficiente. Para tanto, a utilização de ferramentas oferecidas pelos sistemas de informações geográficas, que possibilitam que tal atividade seja realizada de forma sistematizada, com base na topologia das representações geométricas das entidades, é desejável e depende essencialmente dos modelos adotados para o banco de dados geográfico.

No caso estudado, além do sistema de informações geográficas para gestão do cadastro imobiliário, foram desenvolvidas outras aplicações para o banco de dados geográfico, como por exemplo a consulta a fotos de fachada de imóveis. 


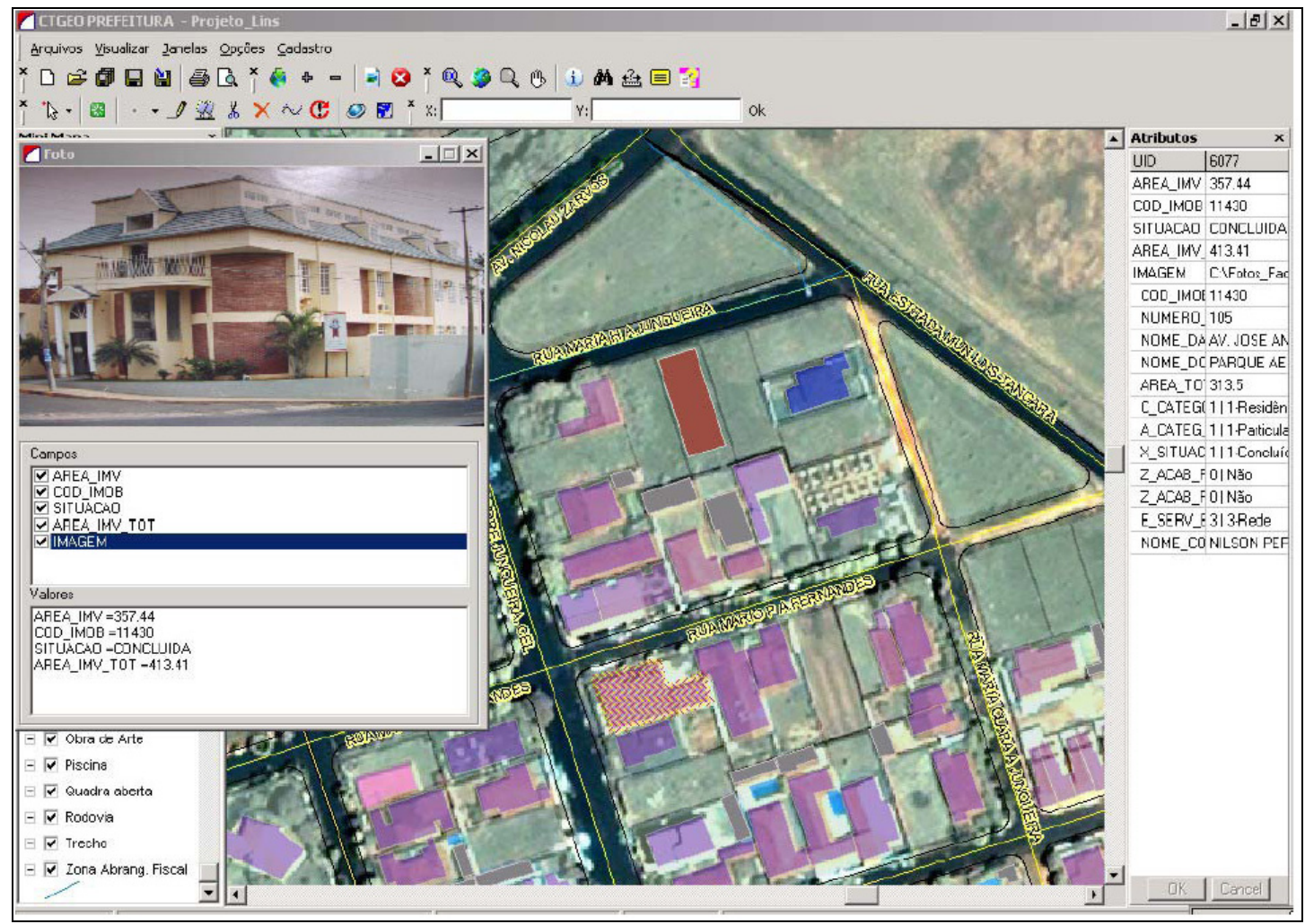

Figura 45 - Aplicação para consulta de foto de fachada de imóvel.

Ademais, o sistema desenvolvido permite a inclusão de novas áreas vetorizadas através de ferramentas específicas e pode acessar, ou mesmo gerar, documentos oficiais, dentre os quais Boletim de Informações Cadastrais (BIC) e certidões, utilizando os dados do cadastro. 


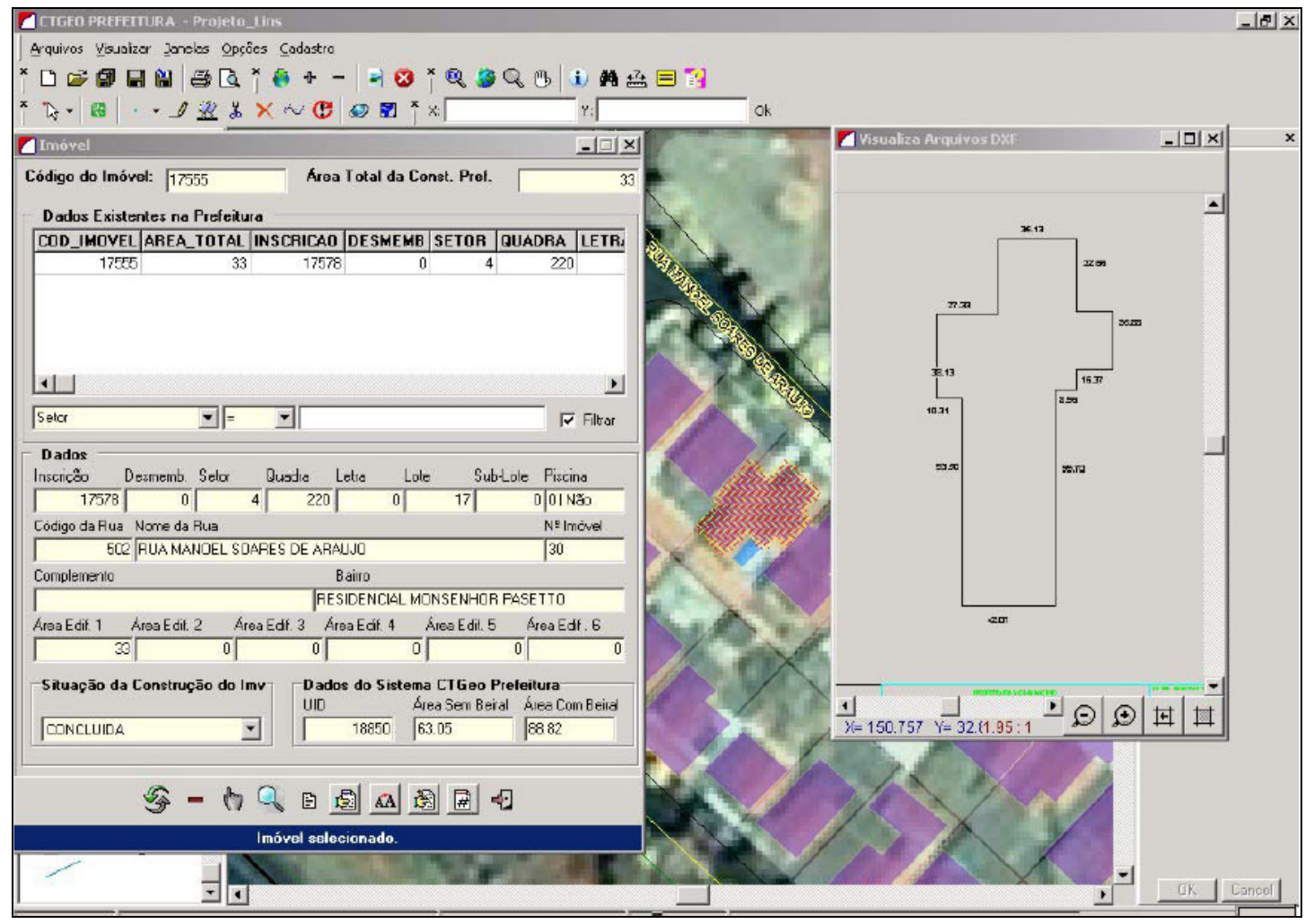

Figura 46 - Aplicação para consulta aos dados do Boletim de Informações Cadastrais (BIC), que pode ser gerado pelo sistema de informações geográficas.

Essas questões envolvem aplicações específicas e, não obstante sua relevância, não implicam em requisitos para a definição de modelos para o banco de dados geográfico. Tais aplicações podem derivar de demandas de diversas áreas de atuação da administração pública municipal e a capacidade do banco de dados geográfico de atender a fins não previstos quando de sua concepção é um requisito importante, tendo em vista o caráter dinâmico do espaço urbano e da sociedade que nele habita.

Dessa forma, o banco de dados geográfico e o sistema de informações geográficas não constituem mero banco de dados com apresentação visual, mas se aproximam mais dos conceitos de sistema ou modelo, relacionando os elementos que o compõem e possibilitando a realização de análises espaciais 
complexas, baseadas em relações topológicas. Permite ainda uma maior integração dos dados de diferentes setores da administração e oferece maior independência e flexibilidade, de modo a acompanhar mais adequadamente as transformações decorrentes da dinâmica urbana social.

Observa-se, por fim, que, no caso estudado, apesar as aplicações desenvolvidas abrangerem essencialmente o atendimento de demandas do cadastro imobiliário, os modelos adotados para dados geográficos e suas representações, entidades e banco de dados, possibilitam a utilização do banco de dados geográfico em diversas aplicações não previstas, como a exemplificada no capítulo anterior. Assim, em processos de concepção de sistemas de informações geográficas, a adoção de modelos adequados para o banco de dados geográfico é fundamental para a determinação dos seus potenciais de utilização nas diferentes áreas de atuação da administração pública municipal. 


\section{REFERÊNCIAS}

BORGES, K. ; DAVIS, C. Modelagem de Dados Geográficos. In: CÂMARA, G. et al. Introdução a Ciência da Geoinformação. São José dos Campos, Instituto Nacional de Pesquisas Espaciais - INPE, 2001. Disponível em $<$ http://www.dpi.inpe.br/gilberto/livro/introd/>.

CÂMARA, G. et al. Análise Espacial de Dados Geográficos. Brasília, $\quad 2004 . \quad$ DMBRAPA, $\quad$ em $<$ http://www.dpi.inpe.br/gilberto/livro/analise/>.

CÂMARA, G. et al. Bancos de Dados Geográficos. São José dos Campos, Instituto Nacional de Pesquisas Espaciais - INPE, 2005. Disponível em $<$ http://www.dpi.inpe.br/livros/bdados/>.

CÂMARA, G.; MONTEIRO, A. M. V. Conceitos Básicos em Ciência da Geoinformação. In: CÂMARA, G. et al. Introdução a Ciência da Geoinformação. São José dos Campos, Instituto Nacional de Pesquisas Espaciais INPE, 2001. Disponível em <http://www.dpi.inpe.br/gilberto/livro/introd/>.

CÂMARA, G. ; QUEIROZ, G. R. Arquiteturas de Sistemas de Informação Geográfica. In: CÂMARA, G. et al. Introdução a Ciência da Geoinformação. São José dos Campos, Instituto Nacional de Pesquisas Espaciais INPE, 2001. Disponível em <http://www.dpi.inpe.br/gilberto/livro/introd/>.

CÂMARA, G. Modelos, linguagens e arquiteturas para banco de dados geográficos. São José dos Campos. Tese de doutorado em computação aplicada - Instituto Nacional de Pesquisas Espaciais - INPE, 1995. Disponível em $<$ http://www.dpi.inpe.br/teses/gilberto/> . 
DATE, C. J. Introdução a Sistemas de Bancos de Dados. Rio de Janeiro, Elsevier, 2003.

DEÁK, C. O Processo de Urbanização no Brasil. São Paulo, Edusp, 2004.

FERRARI, C. Dicionário de Urbanismo. São Paulo, Disal, 2004.

FERRARI, C. Curso de Planejamento Municipal Integrado. São Paulo, Pioneira, 1991.

FONSECA, N. A. A Arquitetura do Mercado Imobiliário e seu

Processo de Produção na cidade de São Paulo. Tese de doutorado apresentada à Faculdade de Arquitetura e Urbanismo da Universidade de São Paulo - FAU USP, 2000.

GIACAGLIA, M. Modelagem de Dados para Planejamento e Gestão Operacional de Transportes. São Paulo. Tese de doutorado em engenharia de transportes - Escola Politécnica da Universidade de São Paulo - POLI USP, 1998.

JACOBS, J. Morte e Vida de Grande Cidades. São Paulo, Martins Fontes, 2003.

LINS, Lei Complementar $n^{\circ}$. 950, de 05 de outubro de 2006. Institui o Plano Diretor do Município de Lins. Diário Oficial do Município.

LINS, Lei Complementar $n^{\circ}$. 1.085, de 15 de agosto de 2008. Dispõe sobre o uso e ocupação do solo urbano de Lins. Diário Oficial do Município. 
ROLNIK, R. et al. Plano Diretor Participativo - Guia para a Elaboração pelos Municípios e Cidadãos. Brasília, MINISTÉRIO DAS CIDADES; CONFEA, 2004.

ROLNIK, R. A Cidade e a Lei: Legislação, Política Urbana e Territórios na Cidade de São Paulo. São Paulo, FAPESP, 2007.

SETZER, V. W. ; SILVA, F. S. C. Bancos de dados. São Paulo, Ed. Edgar Blücher Ltda, 2005.

VILLAÇA, F. As ilusões do Plano Diretor. São Paulo, edição do autor, 2005. Disponível em <http://www.usp.br/fau/fau/galeria/paginas/index.html $>$.

VILLAÇA, F. Espaço Intra-Urbano no Brasil. São Paulo, Studio Nobel, 2001. 